\title{
RELATÓRIO DE INFORMAÇÕES GERENCIAIS DO PODER JUDICIÁRIO DO ESTADO DO RIO DE JANEIRO - 2001-2004
}

\author{
Tribunal De JustiÇa do Estado do Rio de JANEIRo
}

1. APRESENTAÇÃO - 2. DEFINIÇÕES - 3. METODOLOGIA 4. ESCOPO - 5. INDICADORES RELACIONADOS A DESPESAS - 5.1. Indicador de despesas do Sistema Judicial sobre a riqueza do Estado (PIB/RJ) $\left(D_{1}\right)-5.1 .1$. Indicador de despesas com pessoal (orçamento) sobre a riqueza do Estado (PIB/RJ) $\left(D_{1.1}\right)-5.1 .2$. Indicador de despesas de bens e serviços sobre a riqueza do Estado (PIB/RJ) $\left(D_{1.2}\right)-5.2$. Indicador de despesas do Sistema Judicial (orçamento) sobre a despesa pública do Estado $\left(\mathrm{D}_{2}\right):-5.2 .1$. Indicador de despesas de pessoal no Sistema Judicial $\left(D_{2,1}\right)-5.2 .2$. Indicador de despesas do Sistema Judicial com bens e serviços $\left(D_{2.2}\right)-5.3$. Indicador de despesas do Sistema Judicial por habitante $\left(D_{3}\right)-5.4$. Acuracidade entre orçamentos e respectiva execução - 6. INDICADORES RELACIONADOS A PESSOAS - 6.1. Indicador de magistrados por 100.000 habitantes $\left(P_{1}\right)-6.1 .1$. Evolução do quadro da Magistratura do Estado do Rio de Janeiro - 6.2. Indicador de servidores do Judiciário por 100.000 habitantes $\left(P_{2}\right)-6.2 .1$. Distribuição por gênero dos servidores do quadro permanente do PJERJ - 6.3. Indicadores de capacitação de magistrados e de servidores - 6.3.1. Indicador de Aperfeiçoamento de Magistrados - 6.3.2. Indicador de Iniciação e Vitaliciamento - 6.3.3. Indicador de capacitação de servidores - 7 . INDICADORES RELACIONADOS A RECOLHIMENTOS DE VALORES - 7.1. Indicador de recolhimento de taxas e custas sobre despesas do PJERJ $\left(\mathrm{I}_{1}\right)-7.2$. Indicador de arrecadação da dívida ativa do Estado, em relação às despesas do PJERJ $\left(\mathrm{I}_{2}\right)-7.3$. Indicador de depósitos judiciais em processos da Justiça Estadual - 8. INDICADORES RELACIONADOS A INFORMÁTICA - 8.1. Indicador de percentual de despesas com informática $\left(\mathrm{INF}_{1}\right)-8.2$. Indicador número de computadores disponíveis por usuário $\left(\mathrm{INF}_{2}\right)-9$. INDICADORES RELACIONADOS A INFRA-ESTRUTURA - 9.1. Indicador 
de ocupação de área em $\mathrm{m}^{2}\left(\mathrm{M}_{\mathrm{P}}^{2}\right)-9.2$. Indicador de custo do $\mathrm{m}^{2}$ $\left(C_{M}{ }^{2}\right)$ - 9.3. Indicador de processos por $\mathrm{m}^{2}\left(\mathrm{P}_{\mathrm{M} 2}\right)-10$. INDICADORES RELACIONADOS A LITIGIOSIDADE E CARGA DE TRABALHO - 10.1. Indicador de casos novos por 100.000 habitantes $\left(C_{1}\right)-$ 10.2. Indicador de casos novos por magistrado $\left(C_{2}\right)-10.3$. Indicador de taxa de crescimento de casos - 10.4. Indicador de carga de trabalho (K) - 10.5. Indicador de congestionamento (I) - 10.6. Indicador de recorribilidade dos Juizados Especiais às Turmas Recursais (Juizados) - 10.7. Indicador de recorribilidade das Varas ao segundo grau de jurisdição (Seg) - 10.8. Indicador de recorribilidade interna no segundo grau (int) - 10.9. Indicador de recorribilidade ao Supremo Tribunal Federal (STF) - 10.10. Indicador de recorribilidade ao Superior Tribunal de Justiça $\left(V_{S T \jmath}\right)-10.11$. Indicador de reforma da decisão $\left(R_{D}\right)$ - 10.12. Indicador de tempo médio para prolatação de sentenças e acórdãos - 10.13. Indicador de quantidade de sentenças e acórdãos 11. INDICADORES RELACIONADOS AO ACESSO À JUSTIÇA 11.1. Indicador de despesa com assistência judiciária sobre o PIB Estadual $\left(A_{1}\right)-11.2$. Indicador de despesa com assistência judiciária sobre a despesa pública total $\left(A_{2}\right)-11.3$. Indicador de despesa com assistência judiciária gratuita por habitante $\left(A_{3}\right)-11.4$. Indicador de custo unitário de processos julgados $\left(\mathrm{C}_{\mathrm{D}}\right)$ - 11.5. Indicador do número de pessoas atendidas - 11.6. Indicador do grau de satisfação do usuário - 12. INDICADORES RELACIONADOS AO PERFIL DAS DEMANDAS - 13. CONCLUSÕES - 13.1. Gerais - 13.2. Específicas - 13.2.1. como estrutura organizacional (função administrativa): 13.2.2. como instituição intermediadora de conflitos (função jurisdicional): - 14. RESUMO DOS INDICADORES DE DESEMPENHO 15. ANEXO

\section{APRESENTAÇÃO}

Aos 21/07/2004, o Tribunal de Justiça do Estado do Rio de Janeiro concluiu Relatório de Informações Gerenciais sobre o Perfil das Maiores Demandas em curso no Judiciário fluminense, solicitado pelo Senhor Ministro Nelson Jobim, Presidente do Supremo Tribunal Federal, que, como desdobramento, encomendou novo estudo, relacionado a 27 indicadores de desempenho do sistema judicial estadual no século XXI.

O presente Relatório de Informações Gerenciais do Poder Judiciário do Estado do Rio de Janeiro (RIGER PJERJ-1/2005) atende a essa nova solicitação do STF, mediante dados coligidos por suas Diretorias Gerais de Apoio à Jurisdição (DGJUR), de Planejamento, Coordenação e Finanças (DGPCF), de Gestão de Pessoas (DGPES), de Tecnologia da Informação (DGTEC) e de Logística (DGLOG), sob a coordenação do Desembargador Jessé Torres, Gerente do Fundo Especial do Tribunal de Justiça e integrante da Comissão de Gestão Estratégica do PJERJ. 
O RIGER PJERJ-1/2005 descreve o cenário em que atua o Poder Judiciário do Estado do Rio de Janeiro (PJERJ) e dele extrai 57 indicadores objetivos para a formulação de ações tendentes à melhoria da eficiência e da eficácia do sistema judicial ( 30 a mais do que o originalmente solicitado pelo STF). Atém-se à realidade judiciária do Estado, sem embargo de contribuir para a construção de modelos que atendam às peculiaridades de Tribunais federais e de outros Estados, ao exclusivo critério destes ou por inspiração do Supremo Tribunal Federal.

O texto pormenoriza dados e cálculos, desenvolve análises dos indicadores de desempenho e articula a proposição de medidas que estes sugerem à gestão. com vistas ao biênio 2005-2006.

O RIGER PJERJ-1/2005 foi aprovado e teve a sua divulgação recomendada pela Comissão de Gestão Estratégica.

Espera-se do Estado do século XXI que sepulte a relação governante-governado, que caracterizou a vassalagem das populações sujeitas ao absolutismo monárquico; que destine ao limbo da história a insuficiência do absenteísmo liberal, que tudo entregou à imoderação dos mercados e fomentou a dominação pelos mais fortes; que supere para sempre a insensível relação administração-administrado, que estigmatizou o intervencionismo prestador de serviços, inapto para o empreendimento sem lucro; que se lance, enfim, à missão de reduzir desigualdades e discriminações, pela regulação racional dos meios, pela eticidade dos fins e pela efetividade dos resultados.

A sociedade do século XXI quer o Estado garante de todas as gerações de direitos, desde os individuais aos sociais, coletivos e difusos, para o que os poderes constituídos devem operar de modo competente e sintonizados com as necessidades e expectativas de todos os segmentos, a vislumbrar oportunidades de melhorias contínuas, colhendo-as com eficiência e eficácia.

O cidadão do século XXI precisa conhecer os serviços estatais, deles participar e neles confiar, sabendo o que deles esperar, a que custo, em que medida de tempo e com que resultados.

Sob tais perspectivas, a síntese da relação cidadão-justiça no Estado do Rio de Janeiro apresenta, no primeira quadriênio do século XXI. o seguinte perfil objetivo: o funcionamento dos 1.319 órgãos prestadores de jurisidição e unidades administrativas do Judiciário fluminense custa, em média, por ano, $R \$ 87.50$ para cada um dos 15 milhões de habitantes do Estado; esse sistema tem a capacidade de receber, para cada grupo de 16 habitantes, um processo judicial cível e devolvê-lo, 504 dias depois, com a solução técnica do conflito de interesses que o provocou, ao custo final, já contados todos os recursos cabíveis perante a Justiça estadual, de $R \$ 5.970,90$ para os que podem pagar (1/3 dos demandantes), e a custo zero para os que não podem pagar ( $2 / 3$ dos demandantes), e assim tem feito com quase um milhão de processos por ano, desde 2001 , a custo médio de $\mathrm{R} \$$ $1.990,30$ por processo judicial julgado. 


\begin{tabular}{|c|c|}
\hline TERMO & OBJETO \\
\hline $\begin{array}{l}\text { Carta } \\
\text { precatória }\end{array}$ & $\begin{array}{l}\text { Espécie de oficio dirigido por um juiz (deprecante) a outro da mesma } \\
\text { hierarquia (deprecado), solicitando que pratique determinados atos } \\
\text { processuais que não podem ser praticados pelo juiz remetente, por lhe } \\
\text { faltar competência para o exercicio da jurisdição fora de sua Comarca. }\end{array}$ \\
\hline Despesa & $\begin{array}{l}\text { Todo o desembolso público realizado com o fim de atender a serviços e } \\
\text { encargos assumidos no interesse geral da comunidade, nos termos da } \\
\text { Constituição, da lei ou em decorrência de contratos e outros instrumentos. }\end{array}$ \\
\hline $\begin{array}{l}\text { Despesa de } \\
\text { custeio }\end{array}$ & $\begin{array}{l}\text { Desembolso pertinente a gastos com pessoal, material de consumo e } \\
\text { serviços de terceiros. }\end{array}$ \\
\hline $\begin{array}{l}\text { Despesa de } \\
\text { investimento }\end{array}$ & $\begin{array}{l}\text { Desembolso pertinente a gastos com bens permanentes e inversões } \\
\text { financeiras. Sinônimo de despesa de capital. }\end{array}$ \\
\hline $\begin{array}{l}\text { Despesa } \\
\text { empenhada }\end{array}$ & $\begin{array}{l}\text { Obrigação de pagamento contraída pelo Estado, cujo valor é deduzido da } \\
\text { dotação orçamentária (Lei no } 4.320 / 64 \text {, art. } 58 \text { ). }\end{array}$ \\
\hline $\begin{array}{l}\text { Despesa } \\
\text { liquidada }\end{array}$ & $\begin{array}{l}\text { Verificação da regularidade de obrigação financeira devida pelo Estado, cujo } \\
\text { valor é deduzido da respectiva nota de empenho (Lei } n^{\circ} 4.320 / 64 \text {, art. } 63 \text { ). }\end{array}$ \\
\hline $\begin{array}{l}\text { Despesa } \\
\text { paga }\end{array}$ & $\begin{array}{l}\text { Desembolso efetivo de numerário do Estado para o cumprimento de } \\
\text { obrigação de pagamento (Lei } n^{\circ} 4.320 / 64 \text {, art. 64). }\end{array}$ \\
\hline $\begin{array}{l}\text { Fazenda } \\
\text { Pública }\end{array}$ & $\begin{array}{l}\text { Denominação genérica que, historicamente, designa os recursos } \\
\text { financeiros geridos pelo Tesouro, seja o da União, dos Estados ou dos } \\
\text { Municípios (fonte orçamentária código 00). }\end{array}$ \\
\hline JEC & $\begin{array}{l}\text { Juizados Especiais Civeis, que, instalados nas Comarcas do Estado, } \\
\text { processam causas cujo valor individual não ultrapassa } 40 \text { salários mínimos. }\end{array}$ \\
\hline JECRIM & $\begin{array}{l}\text { Juizados Especiais Criminais, competentes para o julgamento de delitos } \\
\text { de menor potencial ofensivo (contravençōes penais e crimes cuja pena } \\
\text { máxima não supere um ano). }\end{array}$ \\
\hline NUR & Núcleo Regional da Justiça do Estado do Rio de Janeiro. \\
\hline Orçamento & $\begin{array}{l}\text { Previsão anual de recursos (receitas e despesas), estabelecida segundo } \\
\text { objetivos e metas traçados pela Lei de Diretrizes Orçamentária - LDO do } \\
\text { Estado do Rio de Janeiro, para cada exercicio financeiro. }\end{array}$ \\
\hline PIB/RJ & Produto Interno Bruto do Estado do Rio de Janeiro. \\
\hline $\begin{array}{l}\text { Precatório } \\
\text { Judicial }\end{array}$ & $\begin{array}{l}\text { Ordem que o Judiciário expede ao Executivo para que este inclua, no } \\
\text { orçamento do exercicio seguinte, valor a ser pago pelo Tesouro a credor } \\
\text { da Fazenda Pública em decorrência de condenação judicial definitiva } \\
\text { (CF/88, art. } 100) \text {. }\end{array}$ \\
\hline
\end{tabular}

1 Art. 100. À exceção dos créditos de natureza alimentícia, os pagamentos devidos pela Fazenda Federal, Estadual ou Municipal, em virtude de sentença judiciária, far-se-ão exclusivamente na ordem cronológica de apresentação dos precatórios e à conta dos créditos respectivos, proibida a designação de casos ou de pessoas nas dotações orçamentárias e nos créditos adicionais abertos para este fim. 


\begin{tabular}{|l|l|}
\hline \multicolumn{1}{|c|}{ TERMO } & \multicolumn{1}{c|}{ OBJETO } \\
\hline RIGER & Relatório de Informações Gerenciais. \\
\hline SIAFEM & $\begin{array}{l}\text { Sistema Integrado de Administração Financeira para Estados e } \\
\text { Municipios. }\end{array}$ \\
\hline $\begin{array}{l}\text { Sistema } \\
\text { DAP }\end{array}$ & $\begin{array}{l}\text { Sistema informatizado responsável pelo controle processual dos feitos em } \\
\text { tramitação nos Juizados Especiais Civeis e Criminais. }\end{array}$ \\
\hline $\begin{array}{l}\text { Sistema } \\
\text { DCP }\end{array}$ & $\begin{array}{l}\text { Sistema informatizado responsável pelo controle processual dos feitos em } \\
\text { tramitação nas Varas de primeiro grau de jurisdição. }\end{array}$ \\
\hline $\begin{array}{l}\text { Sistema } \\
\text { JUD }\end{array}$ & $\begin{array}{l}\text { Sistema informatizado responsável pelo controle processual dos feitos em } \\
\text { tramitação no segundo grau de jurisdição. }\end{array}$ \\
\hline SJ & $\begin{array}{l}\text { Sistema Judicial, composto pelas instituições estaduais que } \\
\text { desempenham as funções essenciais à Justiça: Tribunal de Justiça, } \\
\text { Ministério Público, Procuradoria Geral do Estado e Defensoria Pública } \\
\text { (CF/88 2 artigos 125,127-128, 132 e 133-135); neste Riger, o SJ utiliza } \\
\text { dados referentes, exclusivamente, ao Poder Judiciário. }\end{array}$ \\
\hline
\end{tabular}

\section{METODOLOGIA}

O RIGER PJERJ-1/2005 foi elaborado com base nos seguintes critérios, cuja explicação pormenorizada se encontra no respectivo desenvolvimento:

2 Art. 125. Os Estados organizarão sua Justiça, observados os princípios estabelecidos nesta Constituição.

Art. 127. O Ministério Público é instituição permanente, essencial à função jurisdicional do Estado. incumbindo-lhe a defesa da ordem jurídica, do regime democrático e dos interesses sociais e individuais indisponíveis.

Art. 128. O Ministério Público abrange:

I - o Ministério Público da União, que compreende:

a) o Ministério Público Federal;

b) o Ministério Público do Trabalho:

c) o Ministério Público Militar;

d) o Ministério Público do Distrito Federal e Territórios;

II - os Ministérios Públicos dos Estados.

Art. 132. Os Procuradores dos Estados e do Distrito Federal, organizados em carreira, na qual o ingresso dependerá de concurso público de provas e títulos, com a participação da Ordem dos Advogados do Brasil em todas as suas fases, exercerão a representação judicial e a consultoria jurídica das respectivas unidades federadas. (Redação dada pela Emenda Constitucional $n^{\circ} 19$, de 1998)

Art. 133. O advogado é indispensável à administração da justiça, sendo inviolável por seus atos e manifestações no exercício da profissão, nos limites da lei.

Art. 134. A Defensoria Pública é instituição essencial à função jurisdicional do Estado, incumbindo-lhe a orientação jurídica e a defesa, em todos os graus, dos necessitados, na forma do art. $5^{\circ}$, LXXIV.

Art. 135. Os servidores integrantes das carreiras disciplinadas nas Seções Il e III deste Capítulo serão remunerados na forma do art. $39, \S 4^{\circ}$. (Redação dada pela Emenda Constitucional $n^{\circ} 19$, de 1998) 
a) aplicação de fórmulas de cálculo de indicadores, predefinidas pelo SupremoTribunal Federal ou adaptadas às características do Poder Judiciário do Estado do Rio de Janeiro (CF/88, art. 125), ou de fórmulas por este instituídas para indicadores próprios;

b) análises de despesas baseadas em orçamentos, excluindo o valor de precatórios judiciais por razões especificadas no indicador correspondente:

c) dados e análises correspondentes aos anos de 2001, 2002, 2003 e 2004, ou, alternativamente. se não disponíveis, pertinentes aos anos mais recentes:

d) populações de cada ano, projetadas a partir do Censo de 2000, com base em índices de crescimento demográfico fornecidos pela Fundação Getúlio Vargas;

e) o Produto Interno Bruto do Estado do Rio de Janeiro (PIB/RJ) do ano de $2004 \mathrm{e}$ as despesas do Estado foram projetados a partir dos dados pertinentes a 2001, 2002 e 2003, mediante regressão linear, tendo em vista que esses dados ainda não são conhecidos; a regressão linear tem natureza conservadora, mas, embora a evolução do PIB apresente tendência de crescimento linear, a evolução das despesas tem características exponenciais;

f) informações sobre despesas e orçamentos obtidas junto ao SIAFEM/RJ e ao Centro de Informações de Dados do Rio de Janeiro;

g) as informações de despesas com bens e serviços contemplam, agrupadamente, despesas de custeio e de investimento;

h) exclusão, dos levantamentos estatísticos, de dados relativos a medidas e diligências judiciais que, conquanto tramitem em grande número no cotidiano forense (total de 2.018 .089 no quadriênio pesquisado, na primeira instância e nos Juizados Especiais), esgotam o seu objeto em procedimentos autônomos, independentemente da existência de lide ou da apreciação meritória de lide em curso ou a instaurar-se (cartas precatórias, notificações, protestos, interpelações, justificações e executivos fiscais);

i) exclusão, por indisponíveis, de dados estatísticos referentes ao desempenho das demais funções essenciais à Justiça (Ministério Público, Procuradoria Geral do Estado e Defensoria Pública), seguindo-se que a sigla SJ, utilizada nas fórmulas de cálculo de alguns indicadores, guardará correspondência tão-somente com os dados do PJERJ;

j) exclusão dos valores de precatórios judiciais nos cálculos de indicadores atinentes a despesas, opção explicada no capítulo pertinente;

k) análises de resultados por grupos de;

- despesas;

- integrantes (magistrados, servidores e outros agentes);

- recolhimentos;

- informática;

- utilização de infra-estrutura (menos informática);

- litigiosidade e carga de trabalho;

- acesso à justiça;

- perfil da demanda;

1) grau de incerteza das informações relatadas: em face de o PJERJ ainda não possuir banco de dados normalizado, tal que assegure a integração e a consistência 
dos dados gerados pelos órgãos prestadores de jurisdição e pelas unidades administrativas, cumpre registrar que o grau de confiança das informações e das análises decorrentes porta incertezas intrínsecas à multiplicidade de fontes de coleta de dados, não perdendo, todavia, o valor para formação de juízo sobre a realidade da entrega prestacional no Estado do Rio de Janeiro, nem enevoa o relato fidedigno dessa realidade;

m) opção por padronizar em dois dígitos, quando fracionária, a quantidade de algarismos significativos de todos os indicadores de desempenho; a opção. embora em alguns casos possa parecer exagerada, tem por fim facilitar a futura padronização de expressão dos resultados;

n) sínteses e conclusões finais.

\section{ESCOPO}

Para a definição do escopo da coleta de dados e a respectiva análise foram selecionados os seguintes fatores:

\begin{tabular}{|l|l|}
\hline \multicolumn{1}{|c|}{ FATORES } & \multicolumn{1}{c|}{ PORMENORIZAÇÃO } \\
\hline $\begin{array}{l}\text { Periodo da } \\
\text { pesquisa }\end{array}$ & $\begin{array}{l}\text { Anos de 2001, 2002, 2003 e 2004, conforme a disponbilidade de } \\
\text { dados. }\end{array}$ \\
\hline $\begin{array}{l}\text { Universo de ações } \\
\text { analisadas }\end{array}$ & $\begin{array}{l}\text { Todas as instâncias do Poder Judiciário do Estado do Rio de } \\
\text { Janeiro. }\end{array}$ \\
\hline $\begin{array}{l}\text { Fontes de coleta } \\
\text { de dados }\end{array}$ & $\begin{array}{l}\text { Juizados Especiais Civeis - JEC: banco de dados do Sistema } \\
\text { DAP; } \\
\text { Primeira instância (Varas): banco de dados do Sistema de } \\
\text { Distribuição e Controle Processual da Primeira Instância - DCP; } \\
\text { Segunda instância (Câmaras): banco de dados do Sistema JUD } \\
\text { e exame de autos processuais; } \\
\text { Orçamentos e despesas: Sistema SIAFEM/RJ. }\end{array}$ \\
\hline
\end{tabular}

No período coberto pela pesquisa (2001-2004), tramitaram, pela rede de órgãos prestadores de jurisdição que integram todas as instâncias do Poder Judiciário do Estado do Rio de Janeiro (Órgão Especial, Conselho da Magistratura, Seção Criminal, 114 Juizados Especiais Cíveis, 99 Juizados Especiais Criminais, 503 Varas, 18 Câmaras Cíveis e 8 Câmaras Criminais), 3.214 .936 ações e 391.618 recursos, gerando 3.039.117 julgamentos, dos quais $2.647 .493 \mathrm{em}$ primeiro grau e $391.624 \mathrm{em}$ segundo. Tais números indicam índice de $82,35 \%$ julgados no primeiro grau e de $100 \%$ no segundo grau. 


\section{Quadro 1.1 - Evolução Temporal do Indicador}

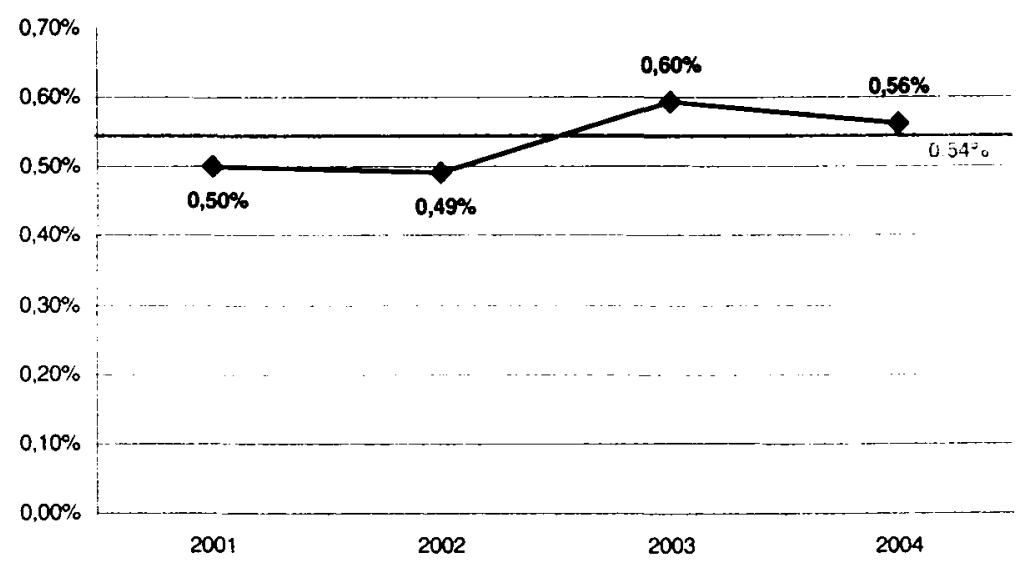

\section{Análise parcial:}

A despesa do SJ acompanha a evolução do PIB. O Indicador D1 manteve-se praticamente estável entre 2001 e 2002 , apresentou crescimento significativo $(22,4 \%)$ entre 2002 e 2003 , e leve declínio entre 2003 e 2004 , mantendo valor superior à média no período observado $(0,54 \%)$. O resultado prenuncia o limiar do reconhecimento da importância de elevar-se o grau de participação do SJ nas políticas públicas, decorrência tardia, porém auspiciosa, das tratativas autorizadas no art. 99 , caput e $\S 1^{\circ}$, da Constituição Federal de $1988^{3}$, que trata da autonomia administrativa e financeira dos Tribunais de Justiça.

5.1.1 Indicador de despesas com pessoal (orçamento) sobre a riqueza do Estado $(P I B / R J)\left(D_{l . l}\right)$

\begin{tabular}{|c|c|}
\hline Fórmula & $D_{1.1\left(P_{\text {essoal }}\right)}=\left(P J_{(\text {Pessoul }} / P \mid B / R J\right)$ \\
\hline \multicolumn{2}{|l|}{ Legenda: } \\
\hline \multicolumn{2}{|c|}{$P J_{(\text {Pessoasi) }}=$ Despesa com pessoal do Poder Judiciário Estadual } \\
\hline \multicolumn{2}{|c|}{ PIB/RJ = Produto Interno Bruto do Estado do Rio de Janeiro } \\
\hline
\end{tabular}

3 Art. 99. Ao Poder Judiciário é assegurada autonomia administrativa e financeira.

Art. $99 \S 1^{\circ}$. Os tribunais elaborarão suas propostas orçamentárias dentro dos limites estipulados conjuntamente com os demais Poderes na lei de diretrizes orçamentárias. 
Quadro 2 - Despesas com pessoal sobre o PIB/RJ

\begin{tabular}{|r|r|r|r|r|}
\cline { 2 - 5 } \multicolumn{1}{c|}{} & \multicolumn{1}{c|}{2001} & \multicolumn{1}{c|}{2002} & \multicolumn{1}{c|}{2003} & \multicolumn{1}{c|}{2004} \\
\hline Dotação Orçamentária & 687.259 .430 & 730.634 .880 & 922.025 .970 & 998.143 .161 \\
\hline PIB/RJ & 168.083 .930 .000 & 191.987 .599 .000 & 213.500 .784 .000 & 236.607 .624 .000 \\
\hline D1.1 (Pessoav) & $0,41 \%$ & $0.38 \%$ & $0.43 \%$ & $0.42 \%$ \\
\hline
\end{tabular}

Quadro 2.1 - Evolução Temporal do Indicador

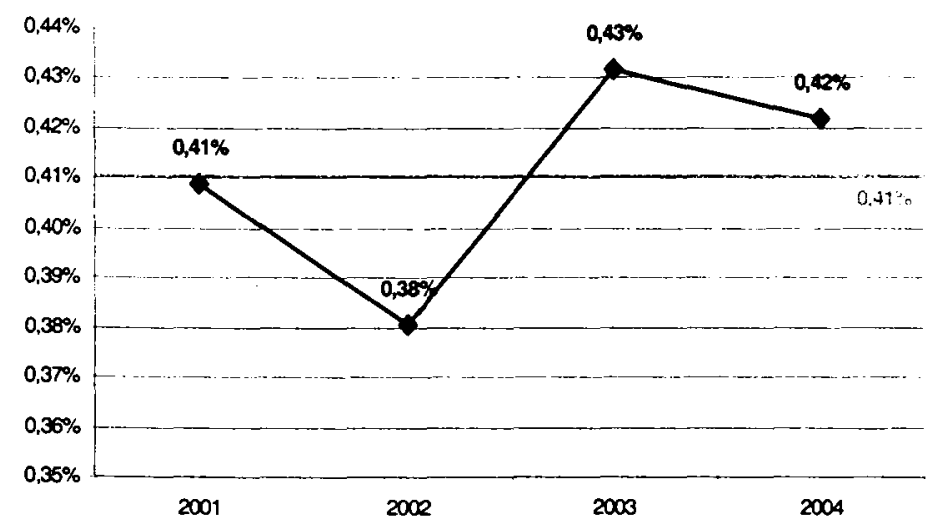

\section{Análise parcial:}

A despesa específica de pessoal do PJERJ acompanha a evolução de crescimento do PIB. O Indicador $D_{1.1}$ apresentou declínio de $7,32 \%$ entre 2001 e 2002 , crescimento de $13,16 \%$ entre 2002 e 2003, voltando a declinar 2,33\% entre 2003 e 2004 . Manteve valor superior à média no período observado $(0,41 \%)$.

5.1.2 Indicador de despesas de bens e serviços sobre a riqueza do Estado $(P I B / R J)\left(D_{l .2}\right)$

\begin{tabular}{|l|l|}
\hline \multicolumn{1}{|c|}{ Fórmula } & $D_{1.2\left(C_{a p}\right)}=\left(P J_{(\text {Cap })} / P / B / R J\right)$ \\
\hline Legenda: & $P J_{(\text {con })}=$ Despesas de Capital do Poder Judiciário Estadual \\
PIB/RJ = Produto Interno Bruto do Estado do Rio de Janeiro \\
\hline
\end{tabular}

\section{Quadro 3 - Despesas do SJ com bens e serviços sobre o PIB/RJ}

\begin{tabular}{|l|r|r|r|r|}
\cline { 2 - 5 } \multicolumn{1}{c|}{} & \multicolumn{1}{c|}{2001} & \multicolumn{1}{c|}{2002} & \multicolumn{1}{c|}{2003} & \multicolumn{1}{c|}{2004} \\
\hline Dotação Orçamentária & 155.350 .000 & 215.549 .190 & 349.995 .720 & 332.205 .000 \\
\hline PIB/RJ & 168.083 .930 .000 & 191.987 .599 .000 & 213.500 .784 .000 & 236.607 .624 .000 \\
\hline D1.2 & $0.09 \%$ & $0.11 \%$ & $0.16 \%$ & $0.14 \%$ \\
\hline
\end{tabular}




\section{Quadro 3.1 - Evolução Temporal do Indicador}

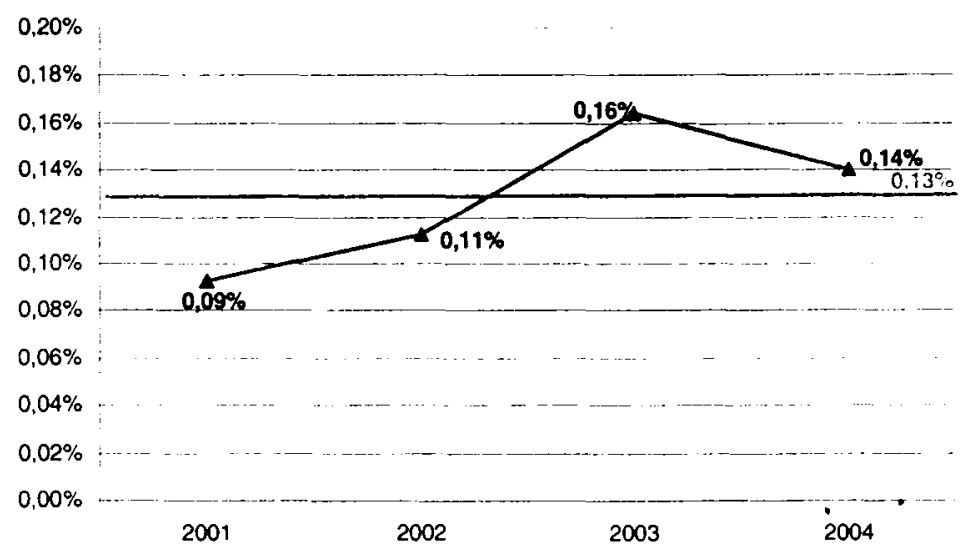

\section{Análise parcial:}

As despesas do PJERJ com bens e serviços (custeio, exceto pessoal, e investimento) são atendidas pelas receitas do Fundo Especial do Tribunal de Justiça do Estado do Rio de Janeiro, suplementadas por convênios firmados com o Banco do Brasil e o BANERJ, que disponibilizaram, entre outubro de 2003 e abril de 2005 , recursos adicionais aos do FETJ, no valor de $\mathrm{R} \$ 144.139 .771,80$, sendo $\mathrm{R} \$$ 135.803.502,13 suplementados pelo Banco do Brasil e $\mathrm{R} \$ \mathrm{R} \$ 8.336 .269,67$ pelo BANERJ.

Os dados analisados mostram tendência de crescimento contínuo de gastos com bens e serviços. $O$ indicador $\mathbf{D}_{1.2}$ cresceu $22,2 \%$ entre 2001 e 2002 , e $45,5 \%$ entre 2002 e 2003; declinou 12,5\% entre 2003 e 2004; manteve valor superior à média no período observado $(0,13 \%)$.

A elevação das despesas do PJERJ, incluindo investimento e custeio, tende a refletir a expansão dos órgãos prestadores de jurisdição de primeiro grau, especialmente mediante a criação de 59 juizados especiais ${ }^{4}$, de 10 foros regionais na Comarca da Capital (estratégia para aproximar as Varas da população nos bairros, ante a saturação do foro central), e de 3 foros de Comarcas do Interior (fruto da emancipação de Municípios - após a CF/88, o número de Municípios fluminenses ${ }^{5}$ cresceu $40 \%$ ).

Essa expansão física poderá não justificar, por si só, toda a elevação das despesas com bens e serviços. Importa verficar a evolução das despesas em cada unidade organizacional do PJERJ, com o fim de identificarem-se os itens que registram os

4 Os Juizados Especiais foram criados pela Lei Estadual $n^{\circ} 2.556 / 96$, em cumprimento à Lei Federal $n^{\circ} 9.099 / 95$. Atualmente, funcionam no Estado do Rio de Janeiro 114 Juizados Especiais Civeis e 99 Criminais.

5 Antes da Constituição de 1988, existiam 66 municípios no Estado do Rio de Janeiro. Atualmente, há 92 municípios. 
maiores índices de aumento (vg., despesas com tarifas de serviços públicos concedidos - energia elétrica, telefonia, água e esgoto -, e com a contratação a terceiros de serviços de limpeza e conservação de instalações prediais). Cogita-se de que medidas racionalizadoras possam contribuir para controlar os gastos decorrentes desses itens.

5.2 Indicador de despesas do Sistema Judicial (orçamento) sobre a despesa pública do Estado $\left(D_{2}\right)$ :

\begin{tabular}{|l|c|}
\hline \multicolumn{1}{|c|}{ Fórmula } & \multicolumn{1}{|c|}{$D_{2}=(S J / D T)$} \\
\hline Legenda: \\
SJ = Despesa do Sistema Judicial no Estado do Rio de Janeiro \\
DT = Despesa Total (orçamento total) do Estado do Rio de Janeiro \\
\hline
\end{tabular}

\section{Quadro 4 - Despesas do SJ sobre a Despesa Pública do Estado}

\begin{tabular}{|l|r|r|r|r|}
\cline { 2 - 5 } \multicolumn{1}{c|}{} & \multicolumn{1}{c|}{2001} & \multicolumn{1}{c|}{2002} & \multicolumn{1}{c|}{2003} & \multicolumn{1}{c|}{2004} \\
\hline Dotação Orçamentária & 842.609 .430 & 946.184 .090 & 1.272 .021 .690 & 1.330 .348 .161 \\
\hline DT & 19.531 .264 .000 & 22.638 .299 .490 & 28.623 .874 .820 & 32.690 .423 .000 \\
\hline D2 & $4,31 \%$ & $4,18 \%$ & $4.44 \%$ & $4,07 \%$ \\
\hline
\end{tabular}

Quadro 4.1 - Evolução Temporal do Indicador

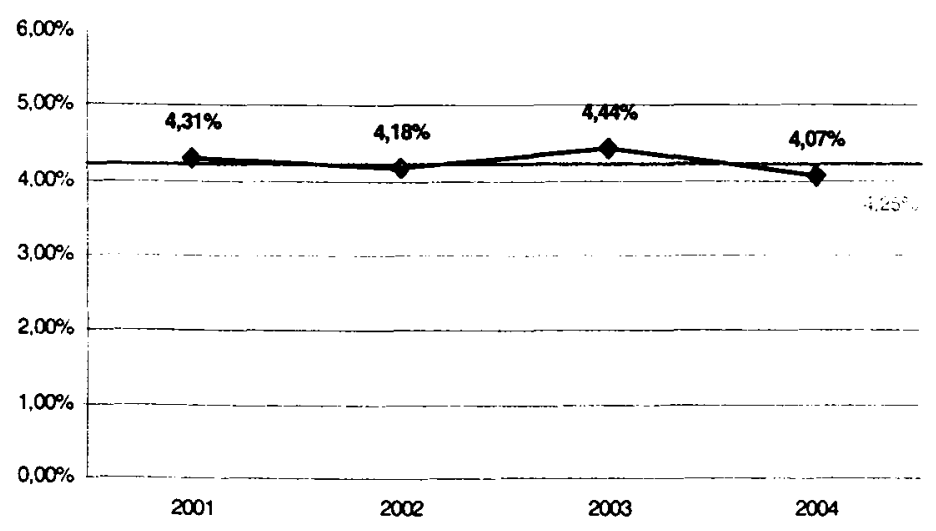

\section{Análise parcial:}

O Indicador $D_{2}$ (gasto do $\mathrm{SJ}$ sobre o gasto público estadual total) mantém comportamento que indica proporcionalidade entre esses dois gastos, com leves oscilações positivas e negativas em torno da média no período observado $(4,25 \%)$. 
Entre 2001 e 2004, ocorreu aumento do PIB/RJ da ordem de $41 \%$. No mesmo período, o gasto público total estadual projetado elevou-se $67 \%$, ao passo que o gasto com o SJ aumentou 58\%, evidenciando que os gastos crescem significativamente mais do que a riqueza. Ressalta-se que o gasto do Estado cresceu nove pontos porcentuais a mais do que o crescimento da despesa do SJ.

Tais ilações merecem atenção ainda maior quando se considera que o crescimento da riqueza (PIB) é linear (mais conservador, em face de agregar toda a história do período observado), enquando que o crescimento das despesas apresenta tendência exponencial, ou seja, mais acelerada nos dois últimos anos. Caso a projeção das despesas do Estado para 2004 fosse feita mediante método matemático polinomial, que parece ser a real natureza da evolução da despesa, o seu crescimento seria de $92 \%$ entre 2001 e 2004, mais do que o dobro do crescimento das respectivas receitas. Nítida rota para o déficit público, habitualmente enfrentado, na cultura político-administrativa brasileira, mediante aumento da carga tributária, o que, como notório, tem ocorrido em relação aos tributos federais e também quanto aos do Estado do Rio de Janeiro, no período observado.

\subsubsection{Indicador de despesas de pessoal no Sistema Judicial $\left(D_{2.1}\right)$}

\begin{tabular}{|l|l|}
\hline \multicolumn{1}{|c|}{ Fórmula } & \multicolumn{1}{c|}{$D_{2.1}=\left(P_{m} / S J\right)$} \\
\hline Legenda: \\
$P_{r m}=$ Despesa com pessoal do Poder Judiciário estadual \\
SJ = Despesa do Sistema Judicial no Estado do Rio de Janeiro \\
\hline
\end{tabular}

Quadro 5 - Despesas do SJ com pessoal sobre a despesa total do SJ

\begin{tabular}{|c|c|c|c|c|}
\hline & 2001 & 2002 & 2003 & 2004 \\
\hline Dotação Orçamentária & 842.609 .430 & 946.184 .090 & 1.272 .021 .690 & 1.330 .348 .161 \\
\hline $\mathrm{P}_{\mathrm{Ph}}$ & 687.259 .430 & 730.634 .880 & 922.025 .970 & 998.143 .161 \\
\hline D2.1 & $81,56 \%$ & $77,22 \%$ & $72,49 \%$ & $75,03 \%$ \\
\hline
\end{tabular}




\section{Quadro 5.1 - Evolução Temporal do Indicador}

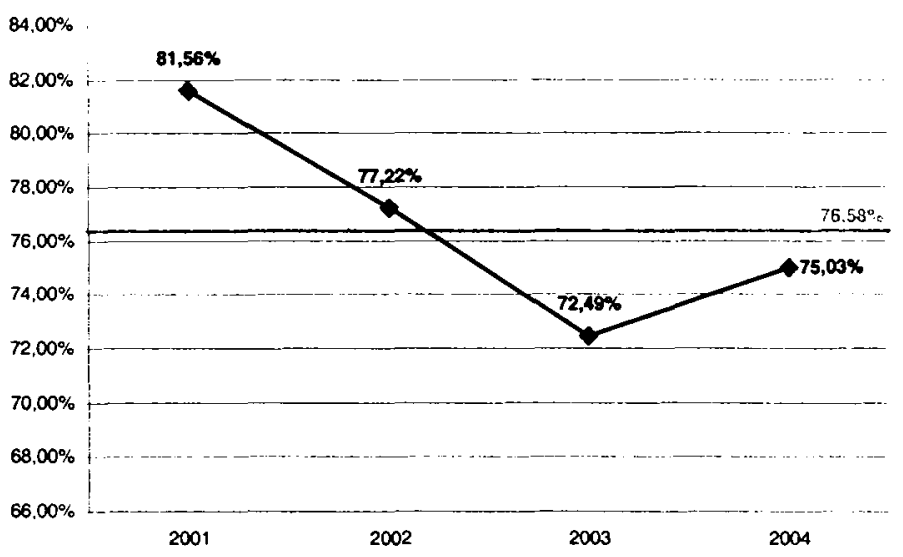

\section{Análise parcial:}

Os dados referem-se, exclusivamente, às despesas com o pessoal ativo do PJERJ. As relativas ao pessoal inativo são cobertas pela Previdência estadual. Embora as despesas com pessoal tenham crescido $45,24 \%$ entre 2001 e 2004 , o indicador $\mathbf{D}_{\mathbf{2 . 1}}$ (gasto de pessoal no SJ) mostra tendência geral declinante, tendo em vista o crescimento mais acentuado da dotação orçamentária do Estado no mesmo período. $\mathrm{O}$ indicador reduziu-se $5,32 \%$ entre 2001 e 2002, e 6,13\% entre 2002 e 2003; cresceu $3,5 \%$ entre 2003 e 2004 , ainda inferior à média no período observado $(76,58 \%)$.

Os aumentos e reduções de despesas com pessoal do PJERJ, sempre contidos nos limites da Lei de Responsabilidade Fiscal (até 6\% sobre a receita líquida do Estado), resultam de: (a) dinamização ou retração no provimento de cargos vagos existentes, cujo número varia em função de aposentadorias, exonerações e demissões; (b) crescimento vegetativo da folha de pagamento, em razão da incorporação de direitos pessoais devidos (tempo de serviço ou gratificações pelo exercício de determinadas funções típicas do escrivão e do oficial de justiça); (c) criação de cargos em correspondência à implantação de foros, comarcas, varas e juizados instituídos por lei.

Convém que o indicador de despesas com pessoal venha, de futuro, a discriminar a contribuição percentual de cada um desses fatores.

\subsubsection{Indicador de despesas do Sistema Judicial com bens e serviços $\left(D_{2.2}\right)$}

\begin{tabular}{|l|l|}
\hline \multicolumn{1}{|c|}{ Fórmula } & $D_{2.2}=\left(B_{s} / S J\right)$ \\
\hline Legenda: & \\
$B_{s}=$ Despesa com bens e serviços do Poder Judiciário estadual \\
SJ = Despesa do Sistema Judicial no Estado do Rio de Janeiro \\
\hline
\end{tabular}




\section{Quadro 6 - Despesas do SJ com bens e serviços sobre a despesa pública do Estado}

\begin{tabular}{|l|r|r|r|r|}
\cline { 2 - 5 } \multicolumn{1}{c|}{} & \multicolumn{1}{c|}{2001} & \multicolumn{1}{c|}{2002} & \multicolumn{1}{c|}{2003} & \multicolumn{1}{c|}{2004} \\
\hline Dotaçāo Orçamentária & 842.609 .430 & 946.184 .090 & 1.272 .021 .690 & 1.330 .348 .161 \\
\hline$B_{\text {s }}$ & 155.350 .000 & 215.549 .190 & 349.995 .720 & 332.205 .000 \\
\hline D2.2 & $18,44 \%$ & $22,78 \%$ & $27.51 \%$ & $24,97 \%$ \\
\hline
\end{tabular}

\section{Quadro 6.1 - Evolução Temporal do Indicador}

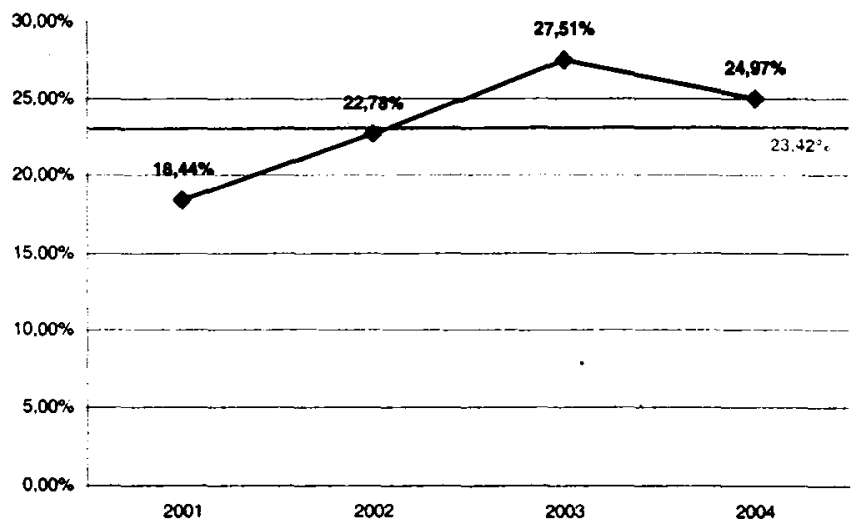

\section{Análise parcial:}

As despesas com bens e serviços no PJERJ acompanharam o aumento geral das despesas do Estado, crescendo cerca de $113 \%$ entre 2001 e 2004. O respectivo indicador $\mathbf{D}_{2.2}$ (gasto com bens e serviços no SJ) cresceu 23,54\% entre 2001 e 2002 , e $20,76 \%$ entre 2002 e 2003; declinou 9,23\% entre 2003 e 2004; manteve-se superior à média no período observado $(23,42 \%)$.

5.3 Indicador de despesas do Sistema Judicial por habitante $\left(D_{3}\right)$

\begin{tabular}{|l|l|}
\hline \multicolumn{1}{|c|}{ Fórmula } & \multicolumn{1}{|c|}{$D_{3}=\left(S J / h_{1}\right)$} \\
\hline Legenda: \\
$S J=$ Despesa do Sistema Judicial no Estado do Rio de Janeiro \\
$h_{1}=$ Número de habitantes no Estado
\end{tabular}




\section{Quadro 7 - Gasto do SJ por habitante}

\begin{tabular}{|c|c|c|c|c|}
\hline & 2001 & 2002 & 2003 & 2004 \\
\hline Dotação Orçamentária & 842.609 .430 & 946.184 .090 & 1.272 .021 .690 & 1.330 .348 .161 \\
\hline População & 14.558 .545 & 14.724 .475 & 14.879 .118 & 15.203 .750 \\
\hline D3 & R\$ 57,88 & $\mathrm{R} \$ 64,26$ & $\mathrm{~A} \$ 85,49$ & $R \$ 87,50$ \\
\hline
\end{tabular}

\section{Quadro 7.1 - Evolução Temporal do Indicador}

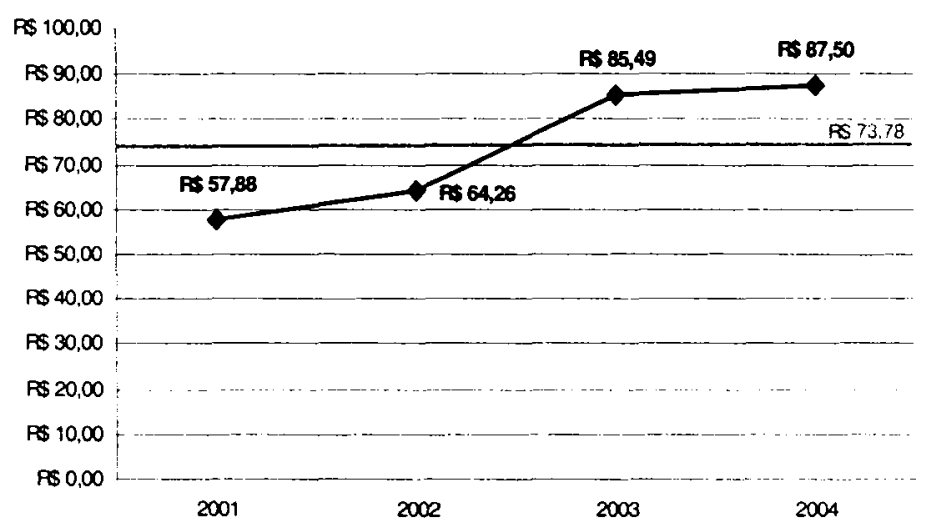

\section{Análise parcial:}

Enquanto a população do Estado cresceu 4,43\% entre 2001 e 2004, as despesas do SJ, expressas em termos de orçamento anual, cresceram 57,88\%. A discrepância percentual seria sugestiva de acumulada defasagem entre o número de demandantes por serviços ao SJ estadual e a capacidade instalada deste para atendê-los. Ao iniciar-se o exercício de 2005, o SJ custava, para cada habitante do Estado do Rio de Janeiro, R\$ 87,50 ao ano, ou 23 centavos por dia. É irrelevante distinguir-se o contingente economicamente ativo da população, de vez que o acesso ao Judiciário é garantido a todo cidadão independentemente de sua condição social ou econômica. Mas importa notar que, segundo apurado no RIGER PJERJ-1/2004, 65\% das ações judiciais são propostas por pessoas hipossuficiantes, às quais é assegurada a gratuidade de justiça (CF/88 6 , art. $5^{\circ}$, LXXIV). Se tal tendência acompanhar o total da população estadual, e apenas $35 \%$ (5.321.313) contarem com meios para custear as

6 A rt. $5^{\circ}$ Todos são iguais perante a lei, sem distinção de qualquer natureza, garantindo-se aos brasileiros e aos estrangeiros residentes no País a inviolabilidade do direito à vida, à liberdade, à iguaidade, à segurança e à propriedade, nos termos seguintes:

LXXIV - o Estado prestará assistência jurídica integral e gratuita aos que comprovarem insuficiência de recursos; 
demandas judiciais, o custo per capita elevar-se-ia para $\mathrm{R} \$ 250,00$ ao ano, ou $\mathrm{R} \$$ 0,68 por dia, não computados os hipossuficientes.

\subsection{Acuracidade entre orçamentos e respectiva execução}

Para efeito de cálculo dos indicadores pertinentes a despesas do SJ, há quatro opções sobre a base de referência: orçamento, despesa empenhada, despesa liquidada e despesa paga. Todas podem introduzir distorções em relação à realidade a ser medida. Escolheu-se a opção "orçamento" porque os valores orçamentários são os que resultam da negociação entre os Poderes $\left(\mathrm{CF} / 88^{7}\right.$, art. $\left.99, \S 1^{\circ}\right)$. Com o fim de apresentar as diferenças entre as quatro opções e avaliar o grau de confiança nos resultados, procedeu-se à análise do grau de acuracidade de execução do orçamento.

\section{Quadro 8 - Acuracidade de execução do orçamento do PJERJ}

\begin{tabular}{|c|c|c|c|c|c|c|c|c|}
\hline \multirow{2}{*}{ Acuracidade } & \multicolumn{2}{|c|}{2001} & \multicolumn{2}{|c|}{2002} & \multicolumn{2}{|c|}{2003} & \multicolumn{2}{|c|}{2004} \\
\hline & Valor & $\%$ & Valor & $\%$ & Valor & $\%$ & Valor & $\%$ \\
\hline Dotaçāo Orçamentária & 842.609 .430 & $100,000 \%$ & 946.184 .090 & $100,000 \%$ & 1.272 .021 .690 & $100,000 \%$ & 1.330 .348 .161 & $100,000 \%$ \\
\hline Despesa Empenhada & 814.376 .230 & $96.649 \%$ & 924.353 .120 & $97.693 \%$ & 1.212 .453 .890 & $95.317 \%$ & 1.284 .791 .361 & $96.576 \%$ \\
\hline Despesa Liquidada & 794.706 .550 & $94,315 \%$ & 894.549 .840 & $94,543 \%$ & 1.169 .751 .220 & $91,960 \%$ & 1.253 .398 .497 & $94,216 \%$ \\
\hline Despesa Paga & 704.184 .140 & $83,572 \%$ & 843.550 .210 & $89,153 \%$ & 1.079 .970 .230 & $84.902 \%$ & 1.192 .232 .208 & $89.618 \%$ \\
\hline
\end{tabular}

A avaliação dos valores apresentados evidencia as seguintes diferenças:

??a despesa empenhada representa, em média, $96,6 \%$ da dotação orçamentária, com desvio padrão de $1,0 \%$;

??a despesa liquidada representa, em média, $93,8 \%$ da dotação orçamentária, com desvio padrão de $1,2 \%$;

??a despesa paga representa, em média, $86,8 \%$ da dotação orçamentária, com desvio padrão de $3,0 \%$.

As diferenças pertinentes às despesas liquidadas e pagas no período indicam a persitente rotina de ser elevada a taxa dos chamados Restos a Pagar, sobejando a cada passagem de exercício financeiro. Se o PJERJ conta com receitas próprias, suficientes e disponíveis, arrecadadas pelo Fundo Especial Especial do Tribunal de Justiça, e trabalha na execução de programas e projetos previstos em planos bienais de investimento, elaborados a partir da solicitação dos gestores, é preciso apurar as razões pelas quais não se realizam plenamente as despesas no mesmo exercício para o qual foram empenhadas: se a raiz dessas diferenças não se encontra no fluxo de caixa, estaria no dimensionamento dado pelos gestores quando solicitam a inserção de projetos no plano bienal, ou na gerência de contratação, fiscalização e execução de programas e projetos, ou na administração dos procedimentos de liquidação da

7 Art. $99, \S 1^{\circ}$ Os tribunais elaborarão suas propostas orçamentárias dentro dos limites estipulados conjuntamente com os demais Poderes na lei de diretrizes orçamentárias. 
despesa, ou em todos esses fatores simultaneamente? Aconselha-se o desdobramento dos indicadores de desempenho com o fim de rever e medir fluxos e prazos na operação dos processos de trabalho de cada segmento.

\section{INDICADORES RELACIONADOS A PESSOAS}

O segundo grupo de indicadores almeja a geração de informações pertinentes a recursos humanos (magistrados, servidores e pessoal auxiliar) alocados para atender à população estadual na entrega da prestação jurisdicional.

\subsection{Indicador de magistrados por 100.000 habitantes $\left(P_{1}\right)$}

A apuração desse indicador distinguiu juízes (primeiro grau de jurisdição) de desembargadores (segundo grau de jurisdição).

\begin{tabular}{|l|l|}
\hline \multicolumn{1}{|c|}{ Fórmula } & $\boldsymbol{P}_{1}=\left(\boldsymbol{M}_{\mathrm{ag}} / \boldsymbol{h}_{\mathbf{2}}\right)$ \\
\hline Legenda: \\
$\boldsymbol{M}_{\mathbf{a g}}=$ Número de magistrados do Estado do Rio de Janeiro por 100.000 \\
habitantes \\
$\boldsymbol{h}_{\mathbf{2}}=$ Número de habitantes no Estado, dividido por 100.000 \\
\hline
\end{tabular}

\section{Quadro 9 - Magistrados por 100.000 habitantes}

\begin{tabular}{|l|c|c|c|c|}
\hline Magistrados por 100.000 habitantes & 2001 & 2002 & 2003 & 2004 \\
\hline Desembargadores & 160 & 159 & 159 & 158 \\
\hline Juizes & 576 & 590 & 618 & 646 \\
\hline População dividida por 100.000 & 145,59 & 147,24 & 148,79 & 152,04 \\
\hline Desembargadores/100.000 hab & 1,10 & 1,08 & 1,07 & 1,04 \\
\hline Juizes/100.000 hab & 3,96 & 4,01 & 4,15 & 4,25 \\
\hline
\end{tabular}

\section{Análise parcial:}

O fato de a população do Estado haver crescido $4,43 \%$ no período entre 2001 e 2004 e o número de juízes (Juizados e Varas) $12,15 \%$ explica a melhoria do indicador. Observa-se que:

- com relação a juízes, houve aumento de $2,43 \%$ entre 2001 e 2002 , de $4,75 \%$ entre 2002 e 2003 , e de $4,53 \%$ entre 2003 e 2004; tal evolução determinou que o respectivo indicador evoluísse, entre 2001 e 2004 , de 3,96 para 4,25 juízes por 100.000 habitantes (crescimento de 7,32\%);

- com relação a desembargadores, houve estabilidade no período;

- com relação à análise conjunta de juízes e desembargadores, houve aumento de $9,23 \%$ no período, decorrente de aumento apenas no número dos primeiros. 
Há cargos não providos de juízes, decorrentes do baixo percentual de aprovação nos concursos realizados (dois por ano, com a média de 1.500 candidatos inscritos em cada qual). Encontram-se em fase de vitaliciamento 54 novos juízes, aprovados no último concurso (segundo semestre de 2004), não incluídos nas estatísticas porque ainda não judicavam no período pesquisado.

\subsubsection{Evolução do quadro da Magistratura do Estado do Rio de Janeiro}

Segue-se a evolução por gênero do quadro da magistratura. Observa-se crescimento de magistrados do sexo feminino tanto entre desembargadores (de 13\%, em 2001, para 19\% em 2004) quanto entre juízes (de 44\%, em 2001 , para $48 \%$ em 2004).

\section{Quadro 10 - Total de Magistrados do PJERJ}

\begin{tabular}{|l|r|r|r|r|r|r|r|r|}
\hline \multirow{2}{*}{\begin{tabular}{|}
\multirow{2}{*}{ Magistrados } \\
\cline { 2 - 9 }
\end{tabular}} & \multicolumn{2}{|c|}{2001} & \multicolumn{2}{c|}{2002} & \multicolumn{2}{c|}{2003} & \multicolumn{2}{c|}{2004} \\
\cline { 2 - 9 } & Homem & Mulher & Homem & Mulher & Homem & Mulher & Homem & Mulher \\
\hline Desembargadores & 139 & 21 & 135 & 24 & 130 & 29 & 128 & 30 \\
\hline Juizes & 320 & 256 & 330 & 260 & 331 & 287 & 336 & 310 \\
\hline Total & 459 & 277 & 465,1 & 283,9 & 461 & 316 & 464 & 340 \\
\hline Total Geral & \multicolumn{2}{|r|}{736} & & 749 & 777 & 804 \\
\hline
\end{tabular}

\section{Quadro 10.1 - Evolução por Gênero do Quadro da Magistratura do PJERJ}

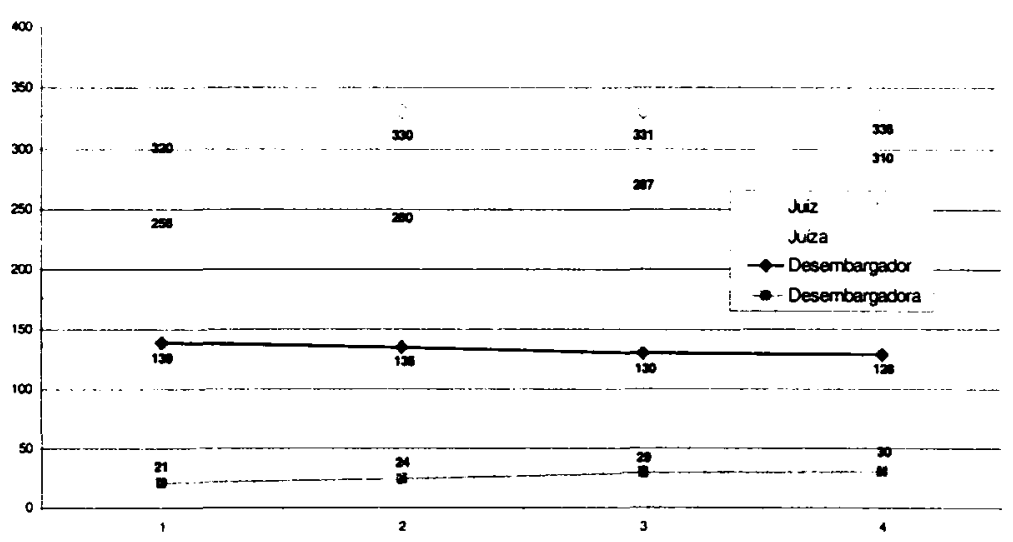

Está sepultado o preconceito de antanho, que supunha a magistratura profissão "masculina". Nos próximos três anos, o número de mulheres tende a superar o de homens na carreira, a persistir o acréscimo feminino à média de $1 \%$ ao ano. Perfil que já é o do quadro de servidores, como se vê adiante. 
6.2 Indicador de servidores do Judiciário por 100.000 habitantes $\left(P_{2}\right)$

\begin{tabular}{|l|l|}
\hline \multicolumn{1}{|c|}{ Fórmula } & \multicolumn{1}{c|}{$\boldsymbol{P}_{2}=\left(\boldsymbol{P}_{\text {aux }} / h_{2}\right)$} \\
\hline Legenda: & \\
$\boldsymbol{P}_{\text {sux }}=$ Total de servidores do Poder Judiciário estadual \\
$\boldsymbol{h}_{2}=$ Número de habitantes no Estado, dividido por 100.000 \\
\hline
\end{tabular}

\section{Quadro 11 - Servidores do Judiciário por 100.000 habitantes}

\begin{tabular}{|c|c|c|c|c|}
\hline Servidores por 100.000 habitantes & 2001 & 2002 & 2003 & 2004 \\
\hline Servidores $\left(P_{\text {aux }}\right)$ & 12.219 & 13.291 & 13.617 & 15.384 \\
\hline População & 14.558 .545 & 14.724 .475 & 14.879 .118 & 15.203 .750 \\
\hline População dividida por $100.000\left(\mathrm{~h}_{2}\right)$ & 145,6 & 147,2 & 148,8 & 152,0 \\
\hline $\mathbf{G}_{7}$ & 83,93 & 90,26 & 91,52 & 101,19 \\
\hline
\end{tabular}

\section{Quadro 11.1 - Evolução Temporal do Indicador}

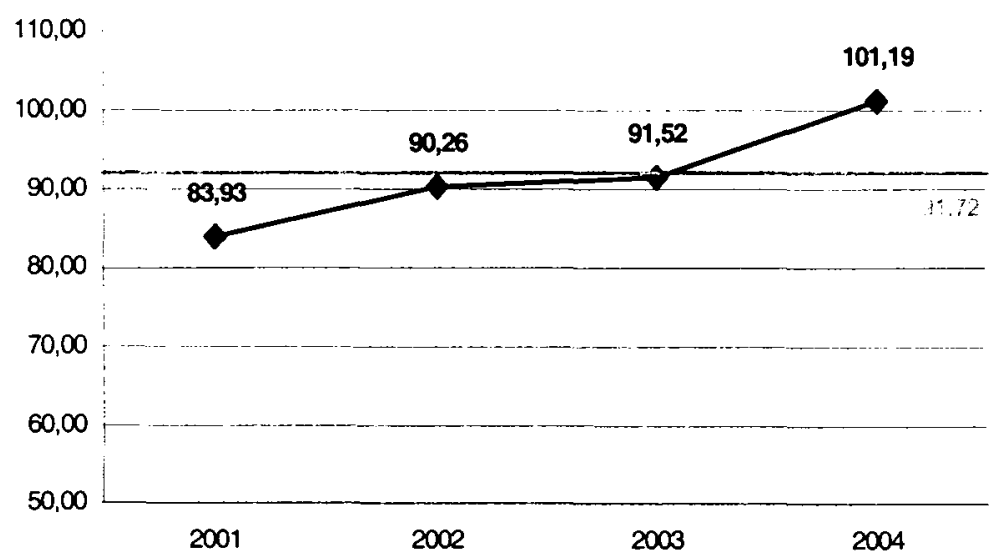

\section{Análise parcial:}

Observam-se aumentos de 7,54\%, entre 2001 e 2002; de $1,40 \%$, entre 2002 e 2003; de 10,57\%, entre 2003 e 2004. A tendência é de crescimento do indicador, embora tenha havido expressiva aposentadoria de servidores no período (133 no ano de $2001 ; 106$, em 2003; 397, em 2003), totalizando 636 servidores com a correspondente substituição no período pesquisado, a indicar, adicionalmente. significativo processo de renovação. 
A renovação de quadros do PJERJ, que tem ocorrido à taxa anual média de $10 \%$, acentua a pioridade estratégica que se tem posto, na gestão de pessoas, sobre os programas de treinamento e aperfeiçoamento permanente de servidores.

Em termos absolutos, a quantidade de servidores por 100.000 habitantes $(101,19$ em 2004) parece elevada, sugerindo baixa automatização dos processos de trabalho. A suspeita contraditaria o apreciável indicador de um computador para cada usuário no PJERJ (ver item 8.2). No entanto, justifica-se a argüição porque o uso mais eficiente do computador demanda a integração de sistemas e a plena exploração de suas funções, o que está ainda em desenvolvimento nas unidades administrativas e em órgãos prestadores de jurisdição.

\section{Quadro 11.2 - Outros Agentes que Atuam no PJERJ}

\begin{tabular}{|c|c|c|c|}
\hline OUTROS AGENTES - 2004 & HOMEM & MULHER & $\begin{array}{c}\text { TOTAL } \\
\text { PARCIAL }\end{array}$ \\
\hline JUÍZES DE PAZ & 225 & 134 & 359 \\
\hline CONCILIADORES & 1.348 & 2.182 & 3.530 \\
\hline ESTAGIÁRIOS & 132 & 222 & 354 \\
\hline TERCEIRIZADOS & 2.051 & 764 & 2.815 \\
\hline TOTAL GERAL & 3.756 & 3.302 & 7.058 \\
\hline
\end{tabular}

\section{Análise parcial:}

Quanto a agentes não-servidores que atuam no PJERJ, conta-se expressiva participação da sociedade civil, realizando atividades de juiz de paz (CF $/ 88^{8}$, art. 98 , II) conciliação $\left(\mathrm{CF} / 88^{9}\right.$, art. $\left.98, \mathrm{I}\right)$, estágio e outras, totalizando 7.058 pessoas, em 2004.

8 Art. 98. A União, no Distrito Federal e nos Territórios, e os Estados criarão:

I - juizados especiais, providos por juizes togados, ou togados e leigos, competentes para a conciliação, o julgamento e a execução de causas civeis de menor complexidade e infrações penais de menor potencial ofensivo, mediante os procedimentos oral e sumaríssimo, permitidos, nas hipóteses previstas em lei, a transação e o julgamento de recursos por turmas de juízes de primeiro grau;

9 Art. 98. A União, no Distrito Federal e nos Territórios, e os Estados criarão:

II - justiça de paz, remunerada, composta de cidadãos eleitos pelo voto direto. universal e secreto. com mandato de quatro anos e competência para, na forma da lei, celebrar casamentos, verificar, de ofício ou em face de impugnação apresentada, o processo de habilitação e exercer atribuições conciliatórias, sem caráter jurisdicional, além de outras previstas na legislação. 
O Quadro 11.3 apresenta a distribuição por gênero dos servidores do PJERJ, em 2004, a saber:

- no Tribunal de Justiça: $40,7 \%$ de homens e $59,3 \%$ de mulheres;

- nos Juizados Especiais: $38,3 \%$ de homens e $61,7 \%$ de mulheres;

- no total de servidores: $40,4 \%$ de homens e $59,6 \%$ de mulheres.

\section{Quadro 11.3 - Distribuição por Gênero dos Servidores do Quadro Permanente}

\begin{tabular}{|l|c|c|c|}
\hline $\begin{array}{c}\text { SERVIDORES DO QUADRO } \\
\text { PERMANENTE - 2004 }\end{array}$ & HOMEM & MULHER & $\begin{array}{c}\text { TOTAL } \\
\text { PARCIAL }\end{array}$ \\
\hline TRIBUNAL DE JUSTIÇA & 5.482 & 7.973 & 13.455 \\
\hline JUIZADOS ESPECIAIS & 739 & 1.190 & 1.929 \\
\hline TOTAL GERAL & $\mathbf{6 . 2 2 1}$ & $\mathbf{9 . 1 6 3}$ & $\mathbf{1 5 . 3 8 4}$ \\
\hline
\end{tabular}

6.3 Indicadores de capacitação de magistrados e de servidores

6.3.1 Indicador de Aperfeiçoamento de Magistrados

Quadro 12 - Aperfeiçoamento de Magistrados

\begin{tabular}{|c|c|}
\hline ANO & PARTICIPANTES \\
\hline 2002 & 3.263 \\
\hline 2003 & 5.291 \\
\hline 2004 & 5.641 \\
\hline
\end{tabular}




\section{Quadro 12.1 - Evolução Temporal do Indicador}

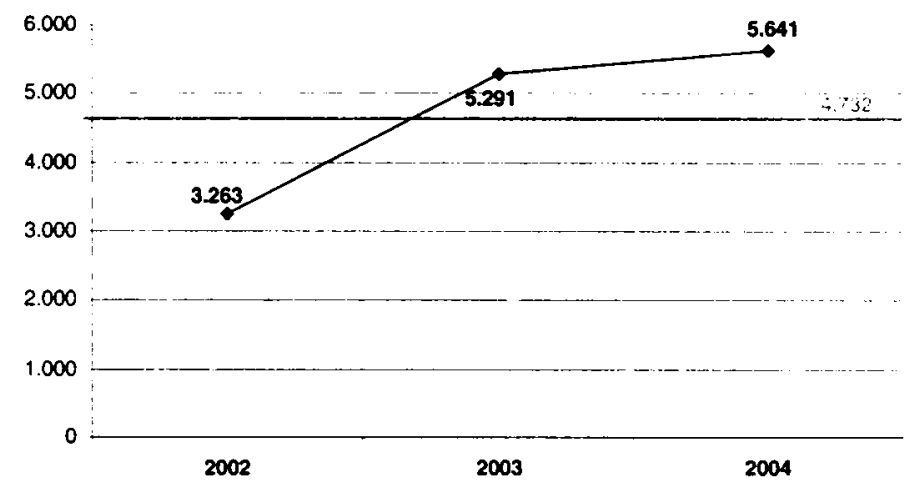

\section{Análise parcial:}

A capacitação de magistrados é realizada mediante o Curso de Aperfeiçoamento, da Escola da Magistratura do Estado do Rio de Janeiro - EMERJ, iniciado em agosto de 2002. Desde então, observa-se crescimento na quantidade de participantes: de $62,15 \%$, entre 2002 e 2003 ; de $6,61 \%$, entre 2003 e 2004, em temas relacionados a direito civil (17\%), direito penal (18\%), processo civil (9\%), processo penal (5\%), infância e juventude (8\%), direito ambiental e eleitoral (6\%), direito empresarial e imobiliário (3\%), direito constitucional, gestão e liderança $(2 \%)$ e outros direitos $(18 \%)$, consolidados em cerca de 500 eventos.

\subsubsection{Indicador de Iniciação e Vitaliciamento}

\section{Quadro 13 - Iniciação e Vitaliciamento}

\begin{tabular}{|c|c|c|}
\hline NÚMERO DO CURSO & ANO & CARGA HORÁRIA \\
\hline XXI & 2000 & 215 \\
\hline XXII & 2001 & 220 \\
\hline XXIII & $2001-2003$ & 306 \\
\hline XXIV & 2002 & 233 \\
\hline XXV & 2003 & 273 \\
\hline$X X V I$ & 2003 & 242 \\
\hline$X X V I I$ & 2004 & 288 \\
\hline
\end{tabular}




\section{Análise parcial:}

Desde julho de 2000, foram constituídas oito turmas do Curso de Iniciação e Vitaliciamento, totalizando 41 eventos e formando 231 juízes vitaliciandos. Em 2004, 72 juízes participaram da capacitação, além de três juízes angolanos. Está em curso o XXVIII Curso de Iniciação e Vitaliciamento, prevendo-se o XXIX para 2005. Todos os cursos são ministrados na EMERJ.

6.3.3 Indicador de capacitação de servidores

Quadro 14 - Capacitação de Servidores

\begin{tabular}{|c|c|c|c|}
\hline ANO & PARTICIPAÇÕES & $\begin{array}{c}\text { CARGA HORÁRIA MÉDIA } \\
\text { POR PARTICIPAÇĀO }\end{array}$ & $\begin{array}{c}\text { QUANTIDADE DE } \\
\text { TURMAS }\end{array}$ \\
\hline 2002 & 15.005 & 15 & 690 \\
\hline 2003 & 23.354 & 17 & 1.444 \\
\hline 2004 & 40.212 & 19 & 1.907 \\
\hline
\end{tabular}

Quadro 14.1 - Evolução Temporal do Indicador

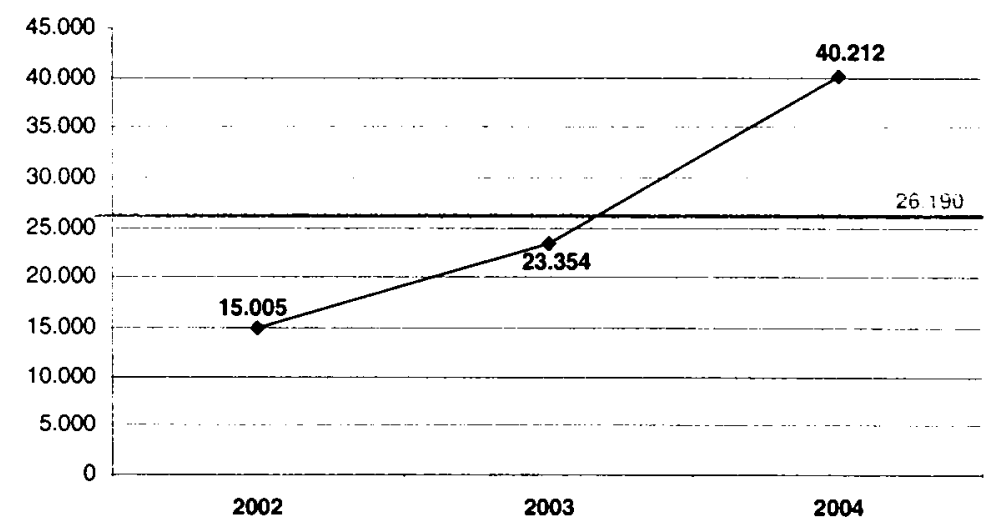

\section{Análise parcial:}

Na capacitação de sevidores, de que se desincumbe a Escola de Administração Judiciária do Estado do Rio de Janeiro - ESAJ, os eventos tratam de temas das áreas comportamental, gerencial, técnica, jurídica, informática e conciliação. Apresenta evolução expressiva no período, em relação a todos os indicadores:

a) em número de participações: crescimento de 55,64\%, entre 2002 e 2003 , e de $72,18 \%$, entre 2003 e 2004; 
b) em carga horária média por participante: crescimento de $13,33 \%$, entre 2002 e 2003 , e de $11,76 \%$, entre 2003 e 2004;

c) em quantidade de turmas por ano: crescimento de $109,27 \%$, entre 2002 e 2003 , e de $32,06 \%$, entre 2003 e 2004.

\section{INDICADORES RELACIONADOS A RECOLHIMENTOS DE VALORES}

O terceiro grupo de indicadores almeja a geração de informações referentes: PJERJ;

a) ao total do recolhimento de taxas e de custas em relação às despesas do

b) ao total da arrecadação do Estado, proporcionada pela cobrança da dívida ativa, em relação às despesas do PJERJ;

c) ao total de depósitos judiciais na arrecadação da dívida ativa.

7.1 Indicador de recolhimento de taxas e custas sobre despesas do PJERJ $\left(I_{l}\right)$

\begin{tabular}{|l|l|}
\hline \multicolumn{1}{|c|}{ Fórmula } & \multicolumn{1}{|c|}{$I_{1}=(T / P J)$} \\
\hline Legenda: \\
$T=$ Taxas e custas recolhidas \\
PJ = Despesa do Poder Judiciário Estadual (orçamento) \\
\hline
\end{tabular}

Quadro 15 - Indicador de recolhimento de taxas e custas

\begin{tabular}{|l|r|r|r|r|}
\hline \multicolumn{1}{|c|}{ Recolhimento de Taxas e Custas } & 2001 & 2002 & 2003 & 2004 \\
\hline Taxas e Custas recolhidas $(T)$ & $168.309 .705,85$ & $191.906 .630,59$ & $209.509 .630,00$ & $242.531 .237,55$ \\
\hline Despesa do Poder Judiciário Estadual (orçamento) & $842.609 .430,00$ & $946.184 .090,00$ & $1.272 .021 .690,00$ & $1.330 .348 .161,00$ \\
\hline Indicador de Recolhimento $\left(I_{1}\right)$ & $19,97 \%$ & $20,28 \%$ & $16,47 \%$ & $18,23 \%$ \\
\hline
\end{tabular}




\section{Quadro 15.1 - Tipificação de recolhimento de taxas e custas}

\begin{tabular}{|c|c|c|c|c|c|}
\hline Taxas a Cuetas recolhidas & 2001 & 2002 & 2003 & 2004 & Acumulado \\
\hline GRERJ & $168.309 .705,85$ & $191.906 .630,59$ & $209.509 .630,00$ & $242.531 .237,55$ & $812.257 .203,99$ \\
\hline Emolumentos & 3.383 .579 .48 & 3.786 .578 .05 & 3.935 .576 .06 & 5.241 .012 .63 & $16.346 .746,22$ \\
\hline Acréscimo 20\% - Lei $3.217 / 99$ & $63.503 .862,68$ & 71.835 .369 .17 & $76.338 .402,42$ & 84.438 .437 .99 & $296.116 .072,26$ \\
\hline Outras receitas & $3.081,66$ & $11.974,30$ & 144.109 .03 & $13.249,98$ & $172.414,97$ \\
\hline Concursos & 6.958 .004 .33 & 6.651 .473 .95 & 86.405 .00 & $6.683 .753,85$ & $20.379 .637,13$ \\
\hline Permissóes de uso & $\$ 51.425,23$ & $347.444,66$ & 630.204 .12 & $1.328 .691,44$ & $2.457 .765,45$ \\
\hline Custas & $30.157 .168,65$ & 33.621 .608 .36 & $44.894 .034,64$ & 53.255 .320 .35 & $161.928 .132,00$ \\
\hline Taxa judiciária & $59.030 .241,03$ & $74.449 .277,26$ & 83.480 .898 .73 & $91.570 .771,31$ & $308.531 .188,33$ \\
\hline Selos & $5.122 .342,79$ & 1.202 .904 .84 & 0,00 & 0,00 & $6.325 .247,63$ \\
\hline Conte corrente & 0,00 & $128.792,22$ & $5.897 .889,24$ & $7.127 .131,23$ & $13.153 .812,69$ \\
\hline Receitas diversas & & & $5.524 .455,59$ & $7.094,168,38$ & $12.618 .623,97$ \\
\hline Permissăo de uso & & $128.792,22$ & $373.433,65$ & $32.962,85$ & $535.188,72$ \\
\hline Convinios da divide ativa & 0,00 & 233,32 & $101.941,66$ & $271.860,81$ & $374.035,79$ \\
\hline São Joăo de Meriti & & 233.32 & $101.941,66$ & $218.834,07$ & $321.009,05$ \\
\hline Niteroi & & & & 53.026 .74 & $53.026,74$ \\
\hline Total Geral & $168.309 .705,85$ & $192.035 .656,13$ & $215.509 .460,90$ & $249.930 .229,59$ & $825.785 .052,47$ \\
\hline
\end{tabular}

\section{Análise parcial:}

As receitas decorrentes de taxas e custas equivaleram, entre 2001 a 2004 , à média de $18,74 \%$ do orçamento global do PJERJ, com desvio padrão de $1,76 \%$, a indicar razoável regularidade. Considerando que as despesas com pessoal (a cargo do Tesouro estadual) respondem por $75 \%$ do orçamento e que as despesas de custeio e investimento no SJ (a cargo do FETJ) correspondem aos $25 \%$ restantes, aquelas receitas não cobrem estas últimas, fato que sinaliza a necessidade de desencadear ações corretivas e preventivas para equilibrar receitas e despesas de investimento e custeio. Até aqui, o equilíbrio tem sido mantido mercê de outras receitas vertidas ao FETJ, inclusive de convênios, porém estudos já indicaram que a velocidade de crescimento das despesas é maior do que a velocidade de crescimento das receitas (DO de 01/02/2005), razão pela qual é necessário, além de incrementar receitas, conter despesas.

7.2 Indicador de arrecadação da dívida ativa do Estado, em relação às despesas do PJERJ $\left(I_{2}\right)$

\begin{tabular}{|l|l|}
\hline \multicolumn{1}{|c|}{ Fórmula } & \multicolumn{1}{|c|}{$I_{2}=(i / P J)$} \\
\hline Legenda: & \\
I= Receitas e recolhimentos diversos \\
PJ = Despesa do Poder Judiciário Estadual (orçamento) \\
\hline
\end{tabular}


Quadro 16 - Indicador de arrecadação do Estado do Rio de Janeiro com dívida ativa

\begin{tabular}{|l|r|r|}
\hline \multicolumn{1}{|c|}{ Imposto } & $\begin{array}{c}\text { Quantidade de } \\
\text { Débitos em } \\
\text { Execuçäo Judicial }\end{array}$ & $\begin{array}{c}\text { Valor Total dos Débitos } \\
\text { em Execução Judiclal }\end{array}$ \\
\hline ICM & 10.712 & $968.265 .562,06$ \\
\hline ICMS & 26.376 & $7.278 .756 .831,04$ \\
\hline IPVA & 1.785 & $5.058 .041,48$ \\
\hline OUTROS TRIB. & 4.908 & $159.712 .222,43$ \\
\hline OUTROS NÁO TRIB. & 6.403 & $152.869 .637,05$ \\
\hline TOTAL & 50.184 & $\mathbf{8 . 5 6 4 . 6 6 2 . 2 9 4 , 0 6}$ \\
\hline
\end{tabular}

\begin{tabular}{|l|r|}
\hline Débitos em Execução em 2004 & $8.564 .662 .296,06$ \\
\hline Despesa do SJ em 2004 & $998.143 .161,00$ \\
\hline Indicador & $8,58 \%$ \\
\hline
\end{tabular}

Encerrado o exercício de 2004, o Cartório da Dívida Ativa do Estado, que funciona junto à $11^{\mathrm{a}}$ Vara de Fazenda Pública, registrava 50.184 processos de execução fiscal ajuizados, por via dos quais o Estado do Rio de Janeiro pretende cobrar, de contribuintes em débito com tributos estaduais, o total de R\$ 8.564.662.294,06 Dessa forma, o indicador apresenta o valor de 8,58\%.

Os débitos decorrentes de ICM (cerca de $11 \%$ do total) têm reduzida probabilidade de recolhimento porque, em boa parte, são devidos por empresas antigas, em especial supermercados, muitas das quais falidas. Dos débitos decorrentes de ICMS e IPVA (cerca de $85 \%$ do total) espera-se poder recolher apenas parte, em face do histórico dessa ação fiscal. Sob perspectiva otimista, estima-se que seria possível recolher-se ao erário algo em torno de dois bilhões de reais, ou seja, cerca de $23 \%$ do total devido. Caso assim se concretizasse, ao FETJ seriam recolhidos R\$ $81.000 .000,00$, a título de taxa judiciária (4\%) e custas processuais (em números redondos, R\$ 114,00 por ação).

\section{Quadro 16.1 - Indicador de arrecadação do Município do Rio de Janeiro com dívida ativa}

\begin{tabular}{|c|c|r|r|}
\hline Ano & Quantidade de Guias & $\begin{array}{c}\text { Total devido ao FETJ - } \\
\text { GRERJ emitidas (R\$) }\end{array}$ & $\begin{array}{c}\text { Total recolhido ao FETJ } \\
\text { (R\$) }\end{array}$ \\
\hline 2002 & 78.405 & $23.322 .414,67$ & $5.223 .581,88$ \\
\hline 2003 & 56.429 & $23.647 .756,19$ & $5.464 .056,84$ \\
\hline 2004 & 80.975 & $43.751 .540,73$ & $5.518 .038,93$ \\
\hline
\end{tabular}




\section{Análise parcial:}

O mesmo acanhado desempenho de cobrança ocorre em relação à dívida ativa dos Municípios, de que é exemplo a da Capital, que expede, mensalmente, guias para a cobrança de débitos referentes a tributos locais. Em 2002, verteu-se ao FETJ $22 \%$ do total devido; em 2003, 23\%; em 2004, 12,61\%.

Em 2003, foi ajuízado o total de R $\$ 892.290 .878,87$, e, em 2004 , R\$ 1.484.550.940,90, dos quais, se pagos, poderiam haver sido recolhidas custas e taxas judiciais.

Os valores totais anuais recolhidos sugerem descolamento entre estes e os valores devidos. Enquanto se verifica expressiva regularidade no recolhimento anual (média de $\mathrm{R} \$ 5.401 .892,55$, com pequeno desvio padrão), o quadro mostra variações fortes, tanto de quantidade de guias emitidas quanto de valores devidos, sinalizando inelasticidade dos recolhimentos em relação à quantidade de guias emitidas e aos valores recolhidos. Estariam os valores recolhidos limitados à capacidade de pagamento das partes devedoras ou à sua efetiva disposição para quitar dívidas judiciais, diante da pouca eficiência dos atuais instrumentos de cobrança?

O Tribunal de Justiça firmou, com 23 dos 92 Municípios fluminenses, convênios visando à efetividade da cobrança de suas respectivas dívidas ativas. Apresentou resultado auspicioso apenas o convênio celebrado com o Município de São João de Meriti, cujos pagamentos obtidos saltaram de $\mathrm{R} \$ 102.174,98$ para $\mathrm{R} \$ 218.834 .07$. entre 2003 e 2004, incremento de $114 \%$ (Relatório do Poder Judiciário do Exercício de 2004, página 117).

O sucesso desse convênio pode ser explicado pela integração da cobrança, em guia única padronizada, de impostos, taxas e honorários, obrigando o devedor a saldá-los integral e concomitantemente (os executores pagavam somente os impostos, livrando-se do risco de ter os seus bens leiloados). Decorre a necessidade de ampliarem-se esses mecanismos mais eficazes de cobrança, neles incluindo a integração dos valores devidos, tal como vem praticando o Município de São João de Meriti, embora todos os demais convênios assim também estabeleçam.

\subsection{Indicador de depósitos judiciais em processos da Justiça Estadual}

\section{Quadro 17 - Valores depositados}

\begin{tabular}{|c|c|}
\hline Ano & Depósitos judiciais \\
\hline 2002 & $2.539 .403,41$ \\
\hline 2003 & $3.777 .184,09$ \\
\hline 2004 & $4.314 .500,32$ \\
\hline
\end{tabular}




\section{Quadro 17.1 - Evolução Temporal do Indicador}

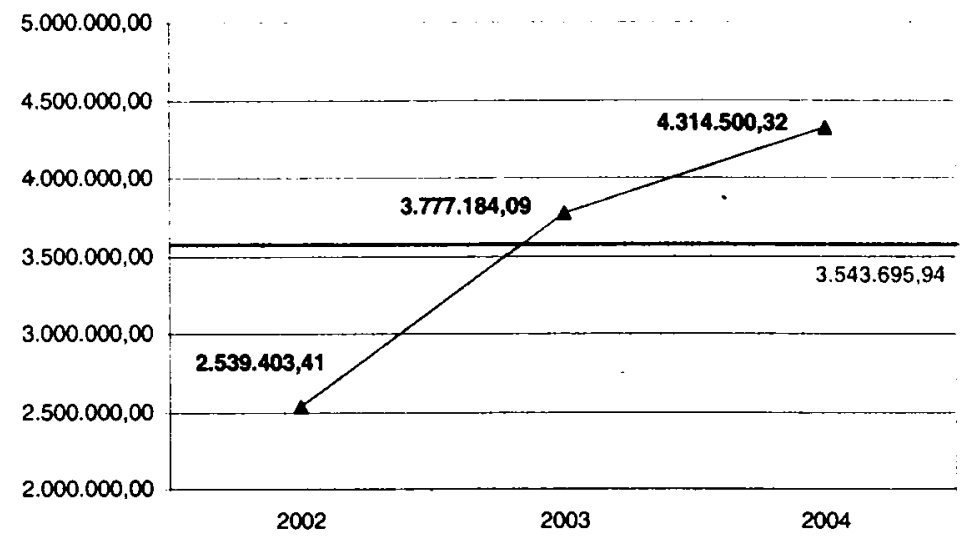

\section{Análise parcial:}

Os depósitos judiciais cresceram 48,74\% entre 2002 e 2003 , e 14,23\% entre 2003 e 2004. A taxa de crescimento tende a declinar, nada obstante o curto período observado. Sublinha-se, também por isto, a necessidade, anotada no item 7.1, retro, de estimular-se o crescimento de outras receitas e a contenção das despesas cobertas pelo FETJ.

\section{INDICADORES RELACIONADOS A INFORMÁTICA}

O quarto grupo de indicadores almeja a geração de informações referentes:

a) ao gasto com informática em relação ao total de despesas do PJERJ;

b) ao número de computadores disponíveis por usuários.

8.1 Indicador de percentual de despesas com informática $\left(\operatorname{lnf}_{l}\right)$

\begin{tabular}{|l|l|}
\hline \multicolumn{1}{|c|}{ Fórmula } & $\quad \ln f_{1}=\left(G_{\operatorname{lnf}} / P J\right)$ \\
\hline Legenda: \\
$G_{m x}=$ Despesas com informática \\
PJ = Despesa do Poder Judiciário Estadual (orçamento) \\
\hline
\end{tabular}

\section{Quadro 18 - Indicador de despesas com informática}

\begin{tabular}{|l|r|r|r|}
\hline \multicolumn{1}{|c|}{ Gastos com informática } & \multicolumn{1}{c|}{2002} & \multicolumn{1}{c|}{2003} & \multicolumn{1}{c|}{2004} \\
\hline Gastos com informática $\left(G_{\text {inf }}\right)$ & $21.646 .001,00$ & $30.836 .649,98$ & $47.209 .921,00$ \\
\hline Despesa do Poder Judiciário Estadual $(\mathrm{PJ})$ & $946.184 .090,00$ & $1.272 .021 .690,00$ & $1.330 .348 .161,00$ \\
\hline Percentual de despesas com informática (lnf1) & $2,29 \%$ & $2,42 \%$ & $3,55 \%$ \\
\hline
\end{tabular}


SJ $\left(I n f_{3}\right)$, também próximo de 1, porém não significa, necessariamente, grau elevado de automação. Trata-se de média matemática, tampouco significando que cada usuário disponha de um computador.

\section{INDICADORES RELACIONADOS A INFRA-ESTRUTURA}

O quinto grupo de indicadores almeja a geração de informações referentes à área física ocupada por pessoa, o custo por metro quadrado e o total por metro quadrado.

9.1 Indicador de ocupação de área em $\mathrm{m}^{2}\left(\mathrm{~m}^{2}\right)$

\begin{tabular}{|l|l|}
\hline \multicolumn{1}{|c|}{ Fórmula } & \multicolumn{1}{|c|}{$\mathrm{m}_{p}^{2}=\left(\mathrm{m}^{2} / \boldsymbol{P}_{\text {aux }}\right)$} \\
\hline Legenda: \\
$\mathrm{m}^{2}=$ Área total do PJERJ e Juizados \\
$P_{\text {aux }}=$ Total de servidores do Poder Judiciário Estadual \\
\hline
\end{tabular}

Quadro 20 - Indicador de Ocupação de Área em m²

\begin{tabular}{|l|r|}
\hline \multicolumn{1}{|c|}{ Ocupação de área em $\mathrm{m}^{2}$} & \multicolumn{1}{|c|}{2004} \\
\hline Área total do PJERJ e Juizados $\left(\mathrm{m}^{2}\right)$ & $410.727,46$ \\
\hline Servidores $\left(\mathrm{P}_{\text {aux }}\right)$ & 15.384 \\
\hline Área ocupada por servidor $\left(\mathrm{m}_{\mathrm{p}}^{2}\right)$ & 26,698 \\
\hline
\end{tabular}

\section{Análise parcial:}

É de 410.727,46 $\mathrm{m}^{2}$ a área ocupada (área construída) pelo PJERJ nas $83 \mathrm{Co}$ marcas do Estado, abrigando as 553 unidades administrativas e os 766 órgãos prestadores de jurisidição (monocráticos, fracionários e colegiados) que conformam a estrutura organizacional consolidada pela Resolução n ${ }^{\circ} 19 / 2004$, do Órgão Especial do Tribunal de Justiça. Equivale a mais que duas vezes a área intra-muros do notório estádio do Maracanã $\left(195.600 \mathrm{~m}^{2}\right)$, sendo que $16 \%\left(65.974,46 \mathrm{~m}^{2}\right)$ dessa área global estão registrados em nome do PJERJ, e $84 \%\left(344.753 \mathrm{~m}^{2}\right)$ correspondem a cessões de uso estaduais e municipais (por exemplo, edificações do Foro Central e terreno onde se edificou o Foro Regional da Barra da Tijuca), comodatos (por exemplo, Juizados Especiais sediados em shopping center) e locações (por exemplo, pavimento no prédio do Jockey Club), ou seja, propriedades de terceiros ocupadas pelo PJERJ.

Nada obstante o desconhecimento de resultados de outras instituições do gênero, o indicador sinaliza aproveitamento inadequado da área disponível. Como termo de comparação, o indicador $\boldsymbol{m}^{2}{ }_{p}$ da $13^{\mathrm{a}}$ Vara Cível da Comarca da Capital, cujo sistema 
de gestão obteve, em 2004, o certificado ISO 9001:2000, é de $6 \mathrm{~m}^{2}$, embora esteja abaixo do que seria ideal.

A discrepância (de $6 \mathrm{~m}^{2}$ para $26 \mathrm{~m}^{2}$ de área ocupada por servidor) reforça a necessidade de estudo especializado sobre a possível existência de espaços ociosos em prédios do PJERJ, ou de espaços desigualmente distribuídos entre a ocupação por servidores e a -ocupação por serviços exigentes de áreas físicas maiores, tais como arquivos, estanterias, balcões e equipamentos por onde tramitam ou são guardados autos de processos e documentos, administrativos e judiciais. Daí se haver incluído o referido estudo no escopo do convênio aditado entre o PJERJ e a FGV para o biênio 2005-2006.

9.2 Indicador de custo do $\mathrm{m}^{2}\left(\mathrm{C}_{m}{ }^{2}\right)$

\begin{tabular}{|l|l|}
\hline \multicolumn{1}{|c|}{ Fórmula } & \multicolumn{1}{|c|}{$C_{m}{ }^{2}=\left(P J / m^{2}\right)$} \\
\hline Legenda: \\
PJ = Despesa do Poder Judiciário Estadual (orçamento) \\
$m^{2}=$ Área total do PJERJ e Juizados \\
\hline
\end{tabular}

Quadro 21 - Indicador de custo do metro quadrado

\begin{tabular}{|l|r|}
\hline \multicolumn{1}{|c|}{ Custo do $\mathrm{m}^{2}$} & \multicolumn{1}{|c|}{2004} \\
\hline Despesa do Poder Judiciário Estadual (PJ) & $1.330 .348 .161,00$ \\
\hline Área total do PJERJ e Juizados $\left(\mathrm{m}^{2}\right)$ & $410.727,46$ \\
\hline Custo do $\mathrm{m}^{2}$ & $3.239,00$ \\
\hline
\end{tabular}

\section{Análise parcial:}

Nada obstante o desconhecimento de resultados comparativos com outras instituições do gênero, o indicador sinaliza elevado custo da área disponível, a recomendar que, uma vez que foros, varas, juizados e cartórios sejam instalados em prédios novos, recém construídos pelo PJERJ, os prédios antigos, cedidos por outras entidades (federais, estaduals, municipais, autárquicas ou privadas), sejam devolvidos aos respectivos donos, desonerando-se o PJERJ da respectiva manutenção. Embora não sejam elementos da mesma natureza, vale lembrar que o custo de construção de edificação nova de bom acabamento, no Rio de Janeiro, em dezembro de 2004, era de $R \$ 813,11$ (indicador Custo Unitário Básico da Construção Civil, em dezembro de 2004 - CRECI/RJ), cerca de quatro vezes menor do que o custo de manutenção por $\mathrm{m}^{2}$ observado no PJERJ. 
9.3 Indicador de processos por $m^{2}\left(P_{m}{ }^{2}\right)$

\begin{tabular}{|l|l|}
\hline \multicolumn{1}{|c|}{ Fórmula } & $\boldsymbol{P}_{m}{ }^{2}=\left(\boldsymbol{P}_{2003} / \boldsymbol{m}^{2}\right)$ \\
\hline Legenda: \\
$\boldsymbol{P}_{2003}=$ Processos em 2003 \\
$\mathrm{~m}^{2}=$ Area total do PJERJ e Juizados \\
\hline
\end{tabular}

Quadro 22 - Indicador de processos por $\mathbf{m}^{2}$

\begin{tabular}{|l|r|}
\hline \multicolumn{1}{|c|}{ Processos por $\mathrm{m}^{2}$} & \multicolumn{1}{c|}{2004} \\
\hline Total de Processos em $2003\left(\mathrm{P}_{2003}\right)$ & $4.270 .285,00$ \\
\hline Área total do PJERJ e Juizados $\left(\mathrm{m}^{2}\right)$ & $410.727,46$ \\
\hline Processos por $\mathrm{m}^{2}\left(\mathrm{P}_{\mathrm{m}}{ }^{2}\right)$ & 10,397 \\
\hline
\end{tabular}

\section{Análise parcial:}

De modo análogo aos indicadores anteriores e pertinentes à infra-estrutura, o indicador de processos por metro quadrado $\left(\boldsymbol{P}_{m}{ }^{2}\right)$ sinaliza aproveitamento quiçá inadequado dos espaços de trabalho, com as ressalvas retro assinaladas.

10 INDICADORES RELACIONADOS A LITIGIOSIDADE E CARGA DE TRABALHO

Desse grupo de indicadores almeja-se a geração de informações referentes:

a) à carga de trabalho de magistrados;

b) ao perfil da demanda jurisdicional; e

c) ao grau de definitividade das ações judiciais que tramitam pelo PJERJ.

10.1 Indicador de casos novos por 100.000 habitantes $\left(C_{1}\right)$

Consideraram-se casos novos:

- na $1^{\mathrm{a}}$ instância;

- na $1^{a}$ instância expurgada (exclusão dos processos relativos a execução fiscal, cartas precatórias, notificações, protestos, interpelações e justificações judiciais);

- na $2^{\mathrm{a}}$ instância;

- nos Juizados Especiais;

- nos Juizados Especiais, com exclusão de cartas precatórias;

- nas Turmas Recursais (instância recursal dos Juizados Especiais).

\begin{tabular}{|l|l|}
\hline \multicolumn{1}{|c|}{ Fórmula } & \multicolumn{1}{c|}{$C_{1}=\left(\mathrm{Cl} / \mathrm{h}_{2}\right)$} \\
\hline Legenda: & \\
$\mathrm{Cl}=$ Casos iniciais (processos tombados) \\
$\mathrm{h}_{2}=$ número total de habitantes no Estado, dividido por 100.000 \\
\hline
\end{tabular}


Quadro 23 - Casos novos por 100.000 habitantes

\begin{tabular}{|l|r|r|r|}
\hline \multicolumn{1}{|c|}{ Casos novos por $\mathbf{1 0 0 . 0 0 0 ~ h a b i t a n t e s ~}$} & \multicolumn{3}{c|}{$\mathbf{2 0 0 1}$} \\
\cline { 2 - 4 } & \multicolumn{1}{c|}{ Cível } & Criminal & \multicolumn{1}{c|}{ Total } \\
\hline $1^{\mathrm{a}}$ Instância Total & 3586,8 & 454,3 & 4041,1 \\
\hline $1^{\text {a }}$ Instância Total Expurgado & 2043,9 & 261,0 & 2304,9 \\
\hline $2^{\mathrm{a}}$ Instância & 376,2 & 85,7 & 461,9 \\
\hline Juizados Especiais & 1470,5 & 754,3 & 2224,8 \\
\hline Juizados Especiais Expurgado & 1364,9 & 704,9 & 2069,8 \\
\hline Turmas Recursais & 91,8 & 2,2 & 94,0 \\
\hline
\end{tabular}

\begin{tabular}{|l|r|r|r|}
\hline \multicolumn{1}{|c|}{ Casos novos por 100.000 habitantes } & \multicolumn{3}{c|}{2002} \\
\cline { 2 - 4 } & \multicolumn{1}{c|}{ Cível } & \multicolumn{1}{c|}{ Criminal } & \multicolumn{1}{c|}{ Total } \\
\hline $1^{\text {a } \text { Instância Total }}$ & 5230,4 & 423,9 & 5654,3 \\
\hline $1^{\text {a } \text { Instância Total Expurgado }}$ & 2099,0 & 245,8 & 2344,8 \\
\hline $2^{\text {a } \text { Instância }}$ & 400,8 & 105,5 & 506,3 \\
\hline Juizados Especiais & 1952,1 & 924,6 & 2876,7 \\
\hline Juizados Especiais Expurgado & 1817,3 & 858,3 & 2675,7 \\
\hline Turmas Recursais & 166,9 & 2,5 & 169,4 \\
\hline
\end{tabular}

\begin{tabular}{|l|r|r|r|}
\hline \multicolumn{2}{|c|}{ Casos novos por $\mathbf{1 0 0 . 0 0 0 ~ h a b i t a n t e s ~}$} & \multicolumn{3}{c|}{$\mathbf{2 0 0 3}$} \\
\cline { 2 - 4 } & \multicolumn{1}{c|}{ Cível } & Criminal & \multicolumn{1}{c|}{ Total } \\
\hline $1^{\mathrm{a}}$ Instância Total & 6286,7 & 583,9 & 6870,6 \\
\hline $1^{\text {a } \text { Instância Total Expurgado }}$ & 2713,7 & 359,8 & 3073,5 \\
\hline $2^{\mathrm{a}}$ Instância & 454,4 & 105,3 & 559,7 \\
\hline Juizados Especiais & 2221,5 & 1098,3 & 3319,8 \\
\hline Juizados Especiais Expurgado & 2059,6 & 1006,0 & 3065,5 \\
\hline Turmas Recursais & 256,6 & 3,2 & 259,8 \\
\hline
\end{tabular}

\begin{tabular}{|l|r|r|r|}
\hline \multicolumn{1}{|c|}{ Casos novos por 100.000 habitantes } & \multicolumn{3}{c|}{2004} \\
\cline { 2 - 4 } & \multicolumn{1}{|c|}{ Cível } & Criminal & \multicolumn{1}{c|}{ Total } \\
\hline $1^{\mathrm{a}}$ Instância Total & 6303,9 & 606,9 & 6910,8 \\
\hline $1^{\mathrm{a}}$ Instância Total Expurgado & 2702,0 & 374,8 & 3076,8 \\
\hline $2^{\mathrm{a}}$ Instância & 497,5 & 103,4 & 600,9 \\
\hline Juizados Especiais & 2209,8 & 1063,9 & 3273,7 \\
\hline Juizados Especiais Expurgado & 2050,0 & 959,7 & 3009,7 \\
\hline Turmas Recursais & 322,1 & 4,0 & 326,1 \\
\hline
\end{tabular}




\section{Análise parcial:}

O Indicador $\mathbf{C}_{1}$ (casos novos por 100.000 habitantes) retrata:

a) com relação a casos novos na $1^{\mathrm{a}}$ instância, excluídos os processos de execução fiscal, cartas precatórias, notificações, protestos, interpelações e justificações:

- no período de 2001 a 2002, crescimento de $1,73 \%$, resultante do aumento de $2,74 \%$ dos processos cíveis e da redução de $6,13 \%$ dos processos criminais, redução esta em contradição com o aumento de violência no Estado, segundo veiculado pela mídia;

- no período de 2002 a 2003, aumento médio de $31,08 \%$, resultante do aumento de $29,25 \%$ dos processos cíveis e do aumento de $46.38 \%$ dos processos criminais; este último percentual exerce diminuta influência sobre o resultado final, porque o volume médio de processos criminais representa cerca de $9 \%$ do volume de processos cíveis;

- no período de 2003 a 2004 , aumento $0,10 \%$, resultante da redução de $0,43 \%$ dos processos cíveis e do aumento de $4,17 \%$ dos processos criminais; este último percentual exerce diminuta influência sobre o resultado final, porque o volume médio de processos criminais representa cerca de $13,87 \%$ do volume de processos cíveis;

b) com relação ao total de casos novos na $2^{\mathrm{a}}$ instância :

- no período de 2001 a 2002, crescimento médio de $9,61 \%$, resultante do aumento de $6,54 \%$ dos processos cíveis e do aumento de $23,10 \%$ dos processos criminais;

- no período de 2002 a 2003, crescimento médio de $10,55 \%$, resultante do aumento de $13,37 \%$ dos processos cíveis e da estabilidade do número de processos criminais, estabilidade essa que surpreende, considerando-se que no mesmo período houve crescimento de $46,38 \%$ em processos criminais na primeira instância, sem gerar correspondente aumento na quantidade de recursos;

- no período de 2003 a 2004, crescimento médio de 7,36\%, resultante do aumento de $9,49 \%$ dos processos cíveis e da redução de $1.80 \%$ dos processos criminais;

c) com relação a casos novos nos Juizados Especiais, com exclusão de cartas precatórias:

- no período de 2001 a 2002, aumento médio de $29,29 \%$, resultante do aumento de $33,15 \%$ dos processos cíveis e do aumento de $21,76 \%$ dos processos criminais;

- no período de 2002 a 2003, aumento médio de $14,57 \%$, resultante do aumento de $13,33 \%$ dos processos cíveis e do aumento de $17,21 \%$ dos processos criminais, indicando tendência de redução de cerca de $50 \%$, tanto dos processos cíveis quanto dos criminais, em relação ao período anterior;

- no período de 2003 a 2004, redução de $1,82 \%$, resultante da redução de $0,47 \%$ dos processos cíveis e da redução de $4,60 \%$ dos processos criminais;

- similarmente ao indicador do total de casos novos nos Juizados Especiais, registra-se crescimento de $45,41 \%$ do total de casos novos, entre 2001 e 2004; nada obstante o expressivo crescimento no quadriênio, a redução dos indicadores entre 
2003 e 2004 pode refletir ou o esgotamento da demanda reprimida por ações judiciais, o que parece pouco provável, ou o descrédito na solução dos conflitos em face do aumento progressivo do tempo de tramitação observado nos Juizados Especiais; seja qual for a possível causa, mostra-se prioritária a adoção de medidas que venham reforçar a capacidade dos Juizados Especiais para atendimento à demanda, cogitando-se, dentre outras, do emprego subsidiário da figura do juiz leigo, prevista no art. 98, I, da CF/88;

d) com relação a casos novos nas Turmas Recursais:

- no período de 2001 a 2002 , aumento médio de $80,21 \%$, resultante do aumento de $81,81 \%$ dos processos cíveis e do aumento de $13,64 \%$ dos processos criminais; sobressai o baixo índice de definitividade das decisões proferidas nos Juizados Especiais Cíveis, já que a maioria desafia recursos;

- no período de 2002 a 2003, aumento médio de $53,36 \%$, resultante do aumento de $53,74 \%$ dos processos cíveis e do aumento de $28 \%$ dos processos criminais;

- no período de 2003 a 2004 , aumento médio de $25,52 \%$, resultante do aumento de $25,53 \%$ dos processos cíveis e do aumento de $25,59 \%$ dos processos criminais.

\subsection{Indicador de casos novos por magistrado $\left(C_{2}\right)$}

Consideraram-se as seguintes situações:

- casos novos (processos tombados) na $1^{\mathrm{a}}$ instância, nos Juizados Especiais e nas Turmas Recursais;

- casos novos (processos tombados) na $1^{a}$ instância, nos Juizados Especiais e nas Turmas Recursais, com exclusão de processos relativos a execução fiscal, cartas precatórias, notificações, protestos, interpelações e justificações judiciais;

- casos novos na $2^{\mathrm{a}}$ instância.

\begin{tabular}{|l|c|}
\hline \multicolumn{1}{|c|}{ Fórmula } & $C_{2}=\left(C I / M_{a g}\right)$ \\
\hline Legenda: & \\
$\mathrm{Cl}=$ Casos iniciais (processos tombados) \\
$M_{\mathrm{ag}}=$ número de magistrados
\end{tabular}

\section{Quadro 24 - Casos novos por magistrado}

\begin{tabular}{|l|r|r|r|}
\hline \multicolumn{2}{|c|}{ Casos novos por Magistrado } & \multicolumn{3}{|c|}{2001} \\
\cline { 2 - 4 } & \multicolumn{1}{|c|}{ Cível } & \multicolumn{1}{c|}{ Criminal } & \multicolumn{1}{c|}{ Total } \\
\hline $1^{\mathrm{a}}$ Instância+Juizados+T. Recursais (Total) & 1306,0 & 307,1 & 1613,1 \\
\hline $1^{\mathrm{a}}$ Instância+Juizados+T. Recursais (Total Expurg.) & 887,9 & 245,5 & 1133,4 \\
\hline $2^{\mathrm{a}}$ Instância & 342,3 & 78,0 & 420,3 \\
\hline
\end{tabular}




\begin{tabular}{|c|c|c|c|}
\hline \multirow{2}{*}{ Casos novos por Magistrado } & \multicolumn{3}{|c|}{2002} \\
\hline & Cível & Criminal & Total \\
\hline $1^{\text {a }}$ Instância+Juizados+T. Recursais (Total) & 1846,7 & 339,5 & 2186,2 \\
\hline $1^{\text {a }}$ Instância+Juizados+T. Recursais (Total Expurg.) & 1026,0 & 278,1 & 1304,1 \\
\hline $2^{\mathrm{a}}$ Instância & 368,9 & 97,1 & 465,9 \\
\hline
\end{tabular}

\begin{tabular}{|c|c|c|c|}
\hline \multirow{2}{*}{ Casos novos por Magistrado } & \multicolumn{3}{|c|}{2003} \\
\hline & Civel & Criminal & Total \\
\hline $1^{\text {a }}$ Instância+Juizados+T. Recursais (Total) & 2079,9 & 400,0 & 2479,9 \\
\hline 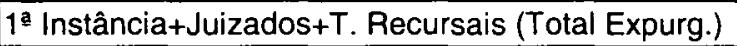 & 1193,6 & 324,9 & 1518,5 \\
\hline 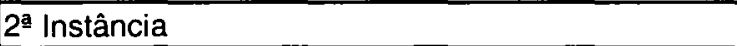 & 422,6 & 97,9 & 520,5 \\
\hline
\end{tabular}

\begin{tabular}{|l|r|r|r|}
\hline \multicolumn{2}{|c|}{ Casos novos por Magistrado } & \multicolumn{3}{c|}{2004} \\
\cline { 2 - 4 } & \multicolumn{1}{|c|}{ Cível } & Criminal & \multicolumn{1}{c|}{ Total } \\
\hline $1^{\text {a }}$ Instância+Juizados+T. Recursais (Total) & 2079,5 & 394,2 & 2473,7 \\
\hline $1^{\text {a }}$ Instância+Juizados+T. Recursais (Total Expurg.) & 1194,2 & 315,0 & 1509,2 \\
\hline $2^{\text {a }}$ Instância & 472,8 & 98,2 & 571,0 \\
\hline
\end{tabular}

\section{Análise parcial:}

O Indicador $\mathbf{C}_{2}$ (casos novos por magistrados) retrata:

a) com relação ao total de casos novos (processos tombados) na $1^{a}$ instância, nos Juizados Especiais e nas Turmas Recursais:

- no período de 2001 a 2002, aumento de 35,53\%, resultante do aumento de $41,40 \%$ dos processos cíveis e do aumento de $10,55 \%$ dos processos criminais;

- no período de 2002 a 2003 , aumento de $13,40 \%$, resultante do aumento de $12,63 \%$ dos processos cíveis e do aumento de $17,82 \%$ dos processos criminais;

- no período de 2003 a 2004, aumento de 7,17\%, resultante do aumento de $4,42 \%$ dos processos cíveis e do aumento do $19,10 \%$ dos processos criminais;

- no período 2001 a 2004 , aumento de $32,71 \%$ de casos novos por magistrado em processos cíveis e de $28,92 \%$ nos processos crimimais, resultando em aumento de $49,49 \%$ do total de casos novos por magistrado;

b) com relação aos casos novos (processos tombados) na $1^{\mathrm{a}}$ instância, nos Juizados Especiais e nas Turmas Recursais, excluídos os processos relativos a execução físcal, cartas precatórias, notificações, protestos, interpelações e justificações judiciais:

- no período de 2001 a 2002 , aumento de $15,06 \%$, resultante do aumento de $15,55 \%$ dos processos cíveis e do aumento de $13,28 \%$ dos processos criminais;

- no período de 2002 a 2003 , aumento de $16,44 \%$, resultante do aumento de $16,34 \%$ dos processos cíveis e do aumento de $16,83 \%$ dos processos criminais; 
- no período de 2003 a 2004 , aumento de $6,17 \%$, resultante do aumento de $5,45 \%$ dos processos cíveis e do aumento do $8,80 \%$ dos processos criminais;

- no período 2001 a 2004 , aumento de $41,76 \%$ de casos novos por magistrado em processos cíveis e de $43,99 \%$ nos processos crimimais, resultando em aumento de $42,24 \%$ do total de casos novos por magistrado; o acréscimo corrobora a observação anotada na análise parcial do indicador $\mathbf{C}_{1}$ (item 10.1, alínea "c");

c) com relação ao total de casos novos (processos tombados) na $2^{\mathrm{a}}$ instância:

- no período de 2001 a 2002, aumento de $10,87 \%$, resultante do aumento de $7,77 \%$ dos processos cíveis e do aumento de $24,49 \%$ dos processos criminais:

- no período de 2002 a 2003 , aumento de $11,70 \%$, resultante do aumento de $14.56 \%$ dos processos cíveis e de estabilidade no volume de processos criminais (aumento de $0,82 \%$ );

- no período de 2003 a 2004, aumento de $9,70 \%$, resultante do aumento de $11,88 \%$ dos processos cíveis e do aumento de $0,31 \%$ dos processos criminais;

- no período 2001 a 2004 , aumento de $33,89 \%$ de casos novos por magistrado, decorrente do aumento de $35,86 \%$ do total de casos novos por magistrado na segunda instância, contra aumento de $33,16 \%$ de casos novos na primeira instância, denotando simetria no crescimento da carga de trabalho, decorrente da incorporação de 72 novos juízes em 2004.

\subsection{Indicador de taxa de crescimento de casos}

Este Indicador está sendo proposto pelo PJERJ com os fins de evidenciar a diversidade de realidades regionais mesmo em Estados de pequenas dimensões físicas, como o do Rio de Janeiro, e de alertar para a necessidade de os indicadores formulados neste RIGER PJERJ-1/2005 levarem em conta as diversidades que poderão ser encontradas nos demais Estados da Federação.

Consideraram-se os seguintes critérios:

- processos tombados e julgados, cíveis e criminais, na $1^{\text {a }}$ instância e nos Juizados Especiais;

- agrupamento, pelos 11 Núcleos Regionais (NUR), definidos pelo Código de Organização e Divisão Judiciárias do Estado do Rio de Janeiro - CODJERJ, de processos tombados e julgados.

O expurgo dos processos relativos a execução fiscal, cartas precatórias, notificações, protestos, interpelações e justificações judiciais, adotado como critério geral neste RIGER PJERJ-1/2005, apresenta-se ainda mais relevante na $1^{\mathrm{a}}$ instância porque, referindo-se a procedimentos em que não se proferem sentenças, sua inclusão no conjunto global dos processos pode deturpar a produtividade dos magistrados, induzindo-lhe significativa redução.

Daí a análise do presente Indicador, quanto ao volume de processos tombados nos anos de 2001, 2002, 2003 e 2004, deixar de considerar os processos expurgados (que não requeriam sentença). 
Quadro 25 - Casos novos tombados e julgados

\begin{tabular}{|l|r|r|r|r|}
\hline \multicolumn{1}{|c|}{ Casos Novos } & \multicolumn{1}{c|}{$\mathbf{2 0 0 1}$} & \multicolumn{1}{c|}{$\mathbf{2 0 0 2}$} & \multicolumn{1}{c|}{$\mathbf{2 0 0 3}$} & \multicolumn{1}{c|}{$\mathbf{2 0 0 4}$} \\
\cline { 2 - 6 } & \multicolumn{1}{c|}{ Total } & \multicolumn{1}{c|}{ Total } & \multicolumn{1}{c|}{ Total } & \multicolumn{1}{c|}{ Total } \\
\hline $1^{\text {a Instância Total }}$ & 588.332 & 832.565 & 1.022 .285 & 1.050 .695 \\
\hline $1^{\text {a Instância Total Expurgado }}$ & 335.556 & 345.260 & 457.316 & 467.790 \\
\hline $2^{\text {a Instância }}$ & 67.250 & 74.551 & 83.285 & 91.356 \\
\hline Juizados Especiais & 323.897 & 423.576 & 493.955 & 497.720 \\
\hline Juizados Especiais Expurgado & 301.328 & 393.976 & 456.124 & 457.586 \\
\hline Turmas Recursais & 13.682 & 24.946 & 38.649 & 49.572 \\
\hline
\end{tabular}

\begin{tabular}{|c|c|c|c|c|}
\hline \multirow{2}{*}{ Julgados } & 2001 & 2002 & 2003 & 2004 \\
\hline & Total & Total & Total & Total \\
\hline $1^{\text {a }}$ Instância (Julgados) & 314.438 & 347.798 & 362.581 & 343.758 \\
\hline 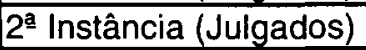 & 65.715 & 78.958 & 83.498 & 86.842 \\
\hline Juizados Especiais & 229.307 & 306.811 & 354.523 & 388.277 \\
\hline Turmas Recursais & 15.142 & 25.294 & 37.069 & 60.105 \\
\hline
\end{tabular}

\section{Análise parcial:}

Como exemplo pontual, no ano de 2002 foram tombados 832.565 processos cíveis na $1^{\mathrm{a}}$ instância, dos quais 487.305 eram da espécie expurgada (não requeriam sentença), representando $58,53 \%$ do total. No ano de 2003 , foram tombados 1.022.285 processos, dos quais 564.969 referiam-se àqueles processos de execução fiscal, cartas precatórias, notificações, protestos, interpelações e justificações judiciais, representando $55,27 \%$. No ano de 2004 , foram tombados 1.050 .695 , dos quais 582.905 pertenciam ao acervo de expurgados, representando $57,02 \%$.

A análise da produtividade dos juízes na prolatação de sentenças na $1^{a}$ instância, no ano de 2003, deve levar em conta os 362.581 processos julgados. que representam $35,47 \%$ do total de processos tombados e $79,28 \%$ daqueles que requeriam sentença. No ano de 2004 , foram julgados 343.758 , o que representa uma redução de $5,19 \%$ em relação ao ano anterior e corresponde a $73,49 \%$ dos processos que requeriam sentença, sinalizando uma contradição, uma vez que em 2004 houve aumento do número de juízes em exercício.

Tal situação não se repete nos Juizados Especiais, nos quais a quantidade de julgamentos (processos que requeriam sentenças), entre 2003 e 2004, cresceu 9,52\%, enquanto o acervo de processos tombados cresceu $32,05 \%$. Cresceu a quantidade de julgamentos, mas a demanda cresce mais rápido do que a oferta da prestação jurisdicional, o que corrobora a premência da medida aviltrada na análise parcial dos indicadores $\mathbf{C}_{1}$ e $\mathbf{C}_{2}$ (itens 10.1 e 10.2). 


\section{Quadro 26: Informação geral sobre os NUR (região e população)}

\begin{tabular}{|c|c|c|c|c|c|c|}
\hline \multirow[b]{2}{*}{ NUR } & \multirow[b]{2}{*}{ Região } & \multicolumn{5}{|c|}{ POPULAÇĀO } \\
\hline & & 2001 & 2002 & 2003 & 2004 & $\begin{array}{l}\% \text { do } \\
\text { total }\end{array}$ \\
\hline $1^{8}$ NUR & Capital & 5.897 .485 & 5.937 .253 & 5.974 .081 & 6.051 .399 & $39,8 \%$ \\
\hline $2^{2} \mathrm{NUR}$ & $\begin{array}{l}\text { Staborai, Maricá, Niterói, Rio Bonito, São Gonçalo, } \\
\text { Silva Jardim, Tanguá }\end{array}$ & 1.735 .855 & 1.758 .766 & 1.780 .566 & 1.826 .325 & $12,0 \%$ \\
\hline $3^{2}$ NUR & $\begin{array}{l}\text { Areal, Comendador Levy Gasparian, Paraiba do Sul, } \\
\text { Petrópolis, São José de Vale do Rio Preto, } \\
\text { Sapucaia,Teresópolis, Très Rios }\end{array}$ & 595.970 & 602.152 & 608.598 & 622.132 & $4,1 \%$ \\
\hline $4^{2} \mathrm{NUR}$ & $\begin{array}{l}\text { Belford Roxo, Duque de Caxias, Guapimirim, Japeri, } \\
\text { Magé, Mesquita, Nilópolis, Nova Iguą̧u, Queimados, } \\
\text { São João de Meriti }\end{array}$ & 3.223 .376 & 3.275 .694 & 3.318 .823 & 3.409 .362 & $22,4 \%$ \\
\hline $5^{9}$ NUR & $\begin{array}{l}\text { Barra do Pirai, Barra Mansa, Itatiaia, Pinheiral, Porto } \\
\text { Real, Quatis, Resende, Rio das Flores, Valença, } \\
\text { Volta Redonda }\end{array}$ & 756.937 & 764.802 & 773.137 & 790.629 & $5,2 \%$ \\
\hline $6^{2}$ NUR & $\begin{array}{l}\text { Cambuci, Campos dos Goytacazes, Carapebus, } \\
\text { Quissamã, Conceição de Macabu, Macaé, São Fidelis, } \\
\text { São Francisco do ltabapoana, São Joāo da Barra }\end{array}$ & 722.040 & 731.725 & 740.204 & 758.005 & $5,0 \%$ \\
\hline TPNUR & $\begin{array}{l}\text { Eng.Paulo de Frontin, Mendes, Miguel Pereira, } \\
\text { Paracambi, Paty do Alferes, Pirai, Vassouras }\end{array}$ & 175.206 & 176.323 & 178.176 & 182.065 & $1,2 \%$ \\
\hline $8^{2}$ NUR & $\begin{array}{l}\text { Angra dos Reis, Itaguai, Mangaratiba, Paraty, Rio } \\
\text { Claro, Seropédica }\end{array}$ & 346.904 & 354.655 & 362.764 & 379.786 & $2,5 \%$ \\
\hline 99 NUR & $\begin{array}{l}\text { Bom Jardim, Cachoeiras de Macacu, Cantagalo, } \\
\text { Carmo, Cordeiro, Duas Barras, Macuco, Nova } \\
\text { Friburgo, Sta Maria Madalena, São Sebastiāo do } \\
\text { Alto, Sumidouro, Trajano de Morais }\end{array}$ & 358.794 & 361.134 & 363.216 & 367.584 & $2,4 \%$ \\
\hline $10^{\circ} \mathrm{N}$ & $\begin{array}{l}\text { Aperibé, Bom Jesus do Itabapoana, Cardoso } \\
\text { Moreira, Italva, Itaocara, Itaperuna, Laje do Muriaé, } \\
\text { Miracema, Natividade, Porciúncula, Sto. Antonio de } \\
\text { Pádua, São José de Ubá, Varre-Sai }\end{array}$ & 285.949 & 288.288 & 290.730 & 295.854 & $1,9 \%$ \\
\hline $11^{2} \mathrm{NU}$ & $\begin{array}{l}\text { Araruama, Armaçāo dos Búzios, Arraial do Cabo, } \\
\text { Cabo Frio, Casimiro de Abreu, Iguaba Grande, Rio } \\
\text { das Ostras, São Pedro da Aldeia, Saquarema }\end{array}$ & 460.029 & 473.683 & 488.823 & 520.609 & $3,4 \%$ \\
\hline & Total Geral & 14.558.545 & 14.724.475 & 14.879.118 & 15.203 .750 & $100 \%$ \\
\hline
\end{tabular}

O quadro 26 apresenta informações gerais sobre os NUR, indicando as cidades que os compõem, o total de suas respectivas populações, bem como a contribuição de cada Núcleo no total da população do Estado. Essa informação tem como finalidade subsidiar as análises apresentadas. O $1^{\circ}$ NUR (Capital) detém $40 \%$ da população do Estado do Rio de Janeiro. O $4^{\circ}$ NUR (Baixada Fluminense) contribui com $22 \%$. O $2^{\circ}$ NUR (Niterói e cidades adjacentes) contribui com $11 \%$. Esses três Núcleos respondem por $74 \%$ da população do Estado, merecendo maior atenção nas análises. 


\section{Quadro 27: Comparativo do número de processos tombados entre $1^{\circ}$ NUR (Capital) e demais NUR}

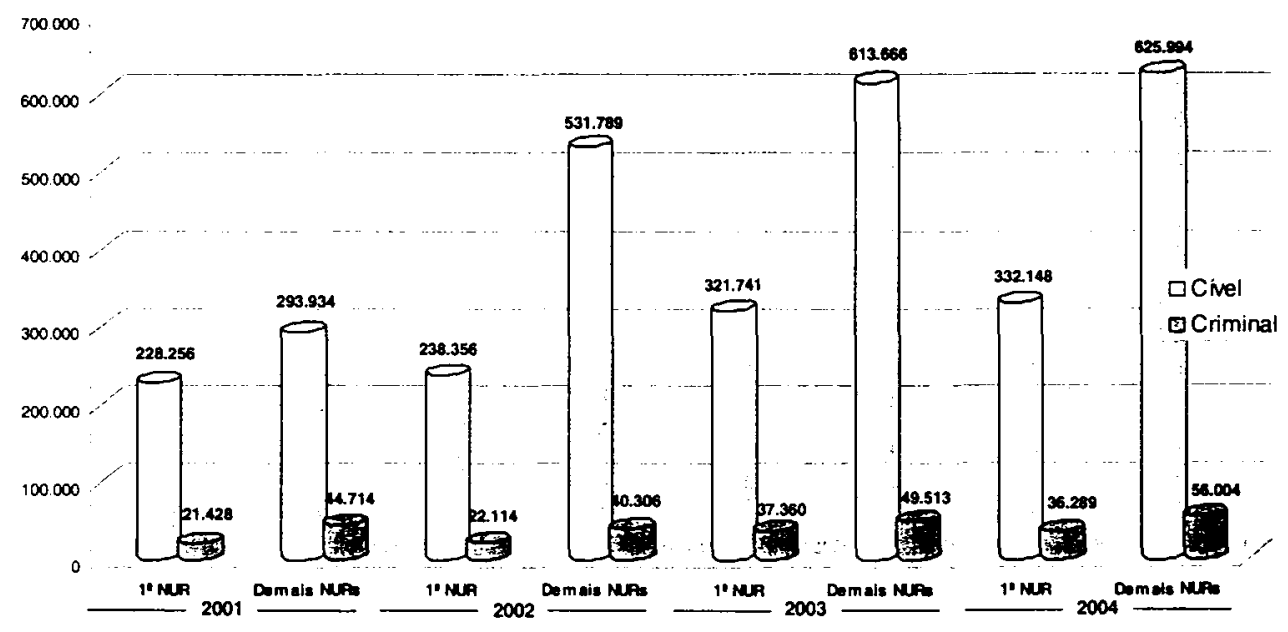

Considerando o período entre 2001 e 2004, observa-se que o $1^{\circ}$ NUR (Capital), que reúne cerca de $40 \%$ da população, responde por cerca de $38 \%$ do volume total de processos. Desse total, o $1^{\circ}$ NUR contribui com $39,32 \%$ dos processos criminais e $34,67 \%$ do volume de processos cíveis. Segue-se que a contribuição do $1^{\circ}$ NUR para o volume de processos cíveis é proporcional à sua população, enquanto que a sua contribuição para o volume de processos criminais é superior à sua participação populacional.

Levando-se em conta a relação entre ações cíveis e ações criminais no período 2001-2004, observa-se, em números redondos, que, quanto a ações cíveis, o $1^{\circ} \mathrm{NUR}$ representa média de $36 \%$ do total, com tendência declinante. Quanto a ações criminais, o $1^{\circ}$ NUR representa $37 \%$ do total, mas com tendência ascendente. Vale dizer que a relação entre processos cíveis e criminais, entre o $1^{\circ}$ NUR e os demais, é aproximadamente a mesma: tende a crescer a contribuição do $1^{\circ}$ NUR em ações criminais, em relação ao total dessas ações, e tende à estabilidade em ações cíveis.

Com relação aos processos cíveis, o $1^{\circ}$ NUR teve crescimento de $4,42 \%$ entre 2001 e 2002 , de $34,81 \%$ entre 2002 e 2003 , e de $3,23 \%$ entre 2003 e 2004 . Nos demais NUR ocorreu crescimento de $80,92 \%$ entre 2001 e 2002 , de $15,40 \%$ entre 2002 e 2003 , e de $2,01 \%$ entre 2003 e 2004 . Dos totais de processos cíveis tombados em 2004 , observa-se que o $1^{\circ}$ NUR (40\% da população) responde por $34,67 \%$ do volume de processos tombados.

Com relação aos processos criminais, o $1^{\circ}$ NUR teve crescimento de $3,20 \%$ entre 2001 e 2002 e de $68,94 \%$ entre 2002 e 2003, e redução de $2,87 \%$ entre 2003 e 2004. Nos demais NUR ocorreu redução de $9,86 \%$ entre 2001 e 2002, crescimento 
de $22,84 \%$ entre 2002 e 2003 , e aumento de $13,11 \%$ entre 2003 e 2004. Dos totais de processos criminais em 2004 , observa-se que o $1^{\circ}$ NUR ( $40 \%$ da população) responde por $39,32 \%$ do volume de processos tombados.

Proporcionalmente, a demanda de processos cíveis cresceu mais no Interior do que na Capital (maior acesso da população à Justiça, decorrente da instalação de foros e juizados no Interior). $\mathrm{O}$ inverso acontece com relação aos processos criminais, malgrado alguma redução de ações entre 2003 e 2004 na Capital. Estaria o fato associado à maior concentração, na Capital, de populações excluídas do processo sócio-econômico-cultural de desenvolvimento dos grandes centros urbanos?

\section{Quadro 28: Estatísticas no $1^{\circ}$ NUR $-1^{a}$ instância (cível e criminal)}

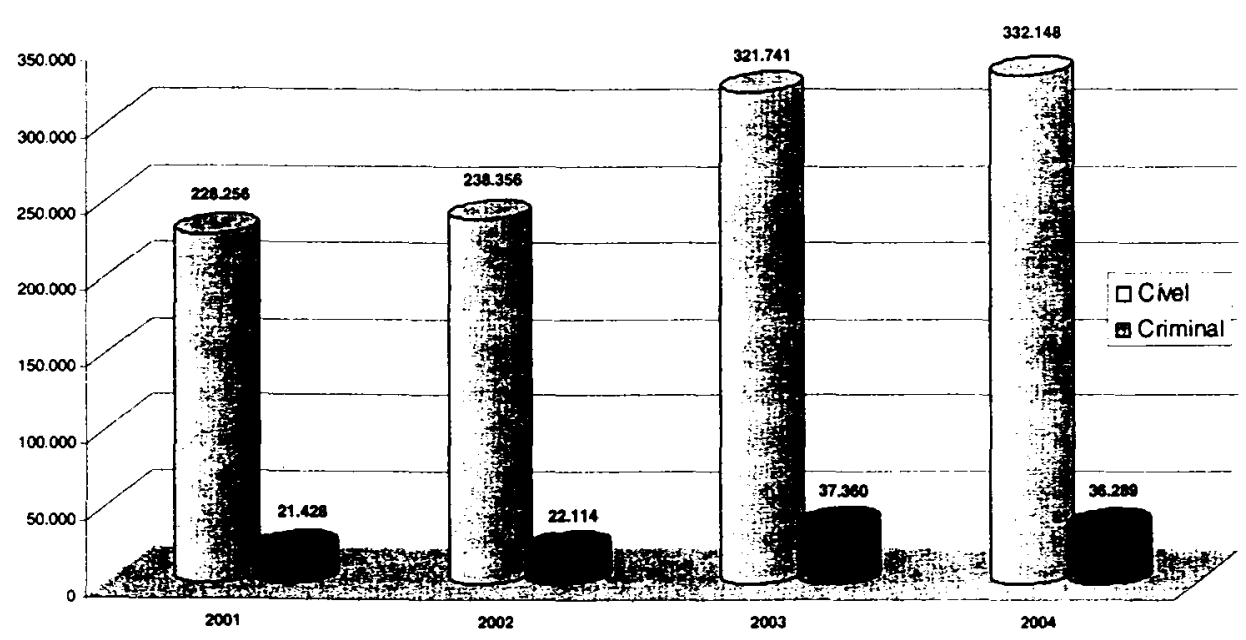

O Quadro 28 destaca que o volume total de processos cíveis no $1^{\circ}$ NUR corresponde a $90,53 \%$ do total de processos tombados, cíveis e criminais, entre 2001 e 2004. No mesmo período, observa-se aumento médio do volume de processos cíveis da ordem de $14,21 \%$, enquanto que o volume de processos criminais cresceu em média $23,09 \%$ ao ano. Tanto com relação aos processos cíveis quanto aos criminais, de 2002 a 2003, observa-se aumento, respectivamente, de $34,98 \%$ e $68,94 \%$; tal anomalia mereceria ser analisada. O maior crescimento dos processos criminais poderia estar reprimido, levando-se em conta a fragilidade, evidenciada por indicadores, das fases pré-judiciárias do sistema (inquérito policial e denúncia pelo Ministério Público). 
Quadro 29 - Total de processos cíveis e criminais na $1^{\text {a }}$ instância, por NUR

\begin{tabular}{|c|c|c|c|c|c|c|}
\hline NUR & 2001 & 2002 & 2003 & 2004 & Total & $\%$ \\
\hline $1^{2}$ NUR & 251.685 & 262.472 & 361.109 & 368.437 & 1.243 .703 & $35,54 \%$ \\
\hline $4^{2}$ NUR & 83.941 & 161.920 & 130.288 & 237.528 & 613.677 & $17,54 \%$ \\
\hline $2^{2}$ NUR & 74.249 & 113.933 & 205.221 & 150.691 & 544.094 & $15,55 \%$ \\
\hline $5^{\circ}$ NUR & 38.080 & 49.985 & 80.389 & 74.235 & 242.689 & $6,93 \%$ \\
\hline $6^{\circ}$ NUR & 25.764 & 40.944 & 79.658 & 86.905 & 233.271 & $6,67 \%$ \\
\hline $3^{9}$ NUR & 25.251 & 106.586 & 33.602 & 31.451 & 196.890 & $5,63 \%$ \\
\hline $8^{9}$ NUR & 21.118 & 25.654 & 49.526 & 19.527 & 115.825 & $3,31 \%$ \\
\hline $11^{\circ}$ NUR & 33.319 & 21.733 & 32.228 & 28.062 & 115.342 & $3,30 \%$ \\
\hline $9^{\circ}$ NUR & 12.653 & 14.173 & 24.815 & 24.593 & 76.234 & $2,18 \%$ \\
\hline $10^{\circ}$ NUR & 16.977 & 19.021 & 14.902 & 13.759 & 64.659 & $1,85 \%$ \\
\hline $7^{9}$ NUR & 7.296 & 18.146 & 12.550 & 15.247 & 53.239 & $1,52 \%$ \\
\hline Total & 590.333 & 834.567 & 1.024 .288 & 1.050 .435 & 3.499 .623 & $100,00 \%$ \\
\hline
\end{tabular}

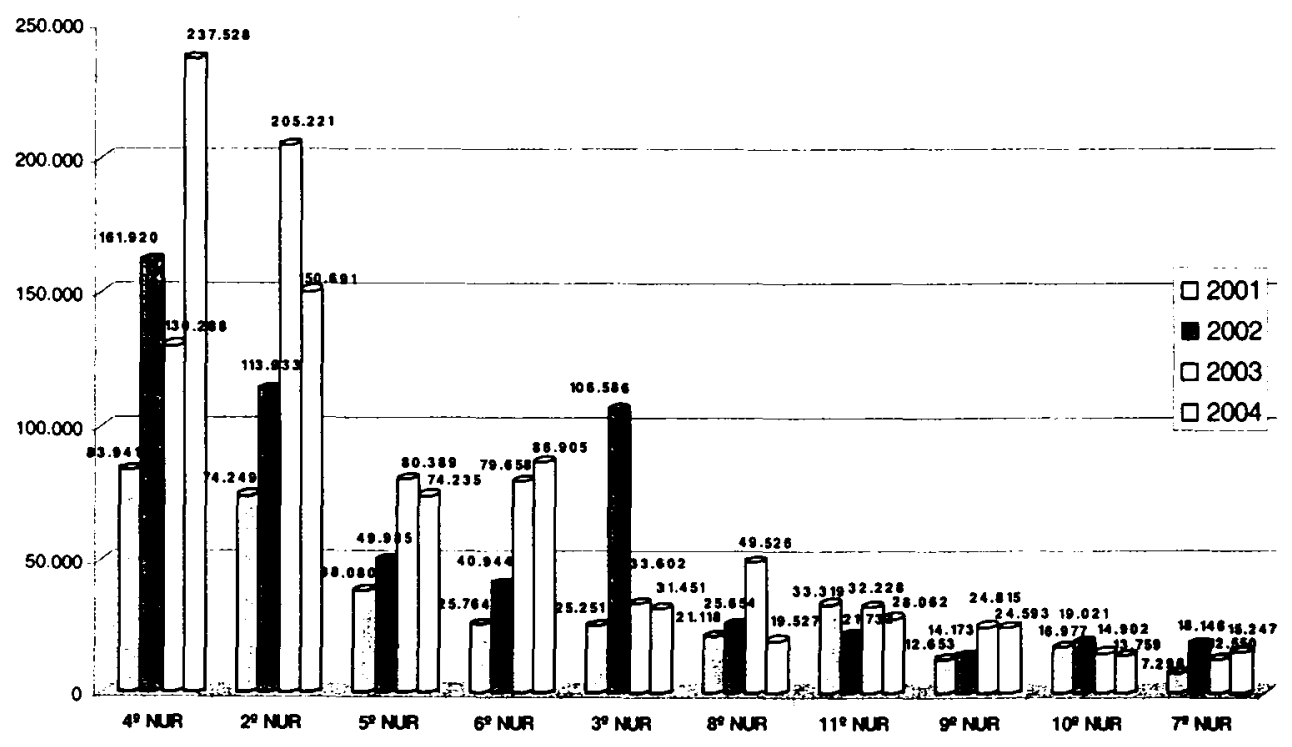

O Quadro 29 mostra o peso do $2^{\circ}$ e do $4^{\circ}$ NUR, cujas respectivas populações somam $34 \%$ da população do Estado, respondendo por $51,32 \%$ do total dos processos tombados entre 2001 e 2004 , excluindo o $1^{\circ}$ NUR. O três maiores NUR $\left(1^{\circ}, 2^{\circ}\right.$ e $\left.4^{\circ}\right)$ respondem, portanto, por $68,63 \%$ das ações ajuizadas. O quadro a seguir apresenta a contribuição de cada NUR, sinalizando para provável distribuição de prioridades. 
Quadro 30: Total de processos cíveis na $1^{\mathrm{a}}$ instância

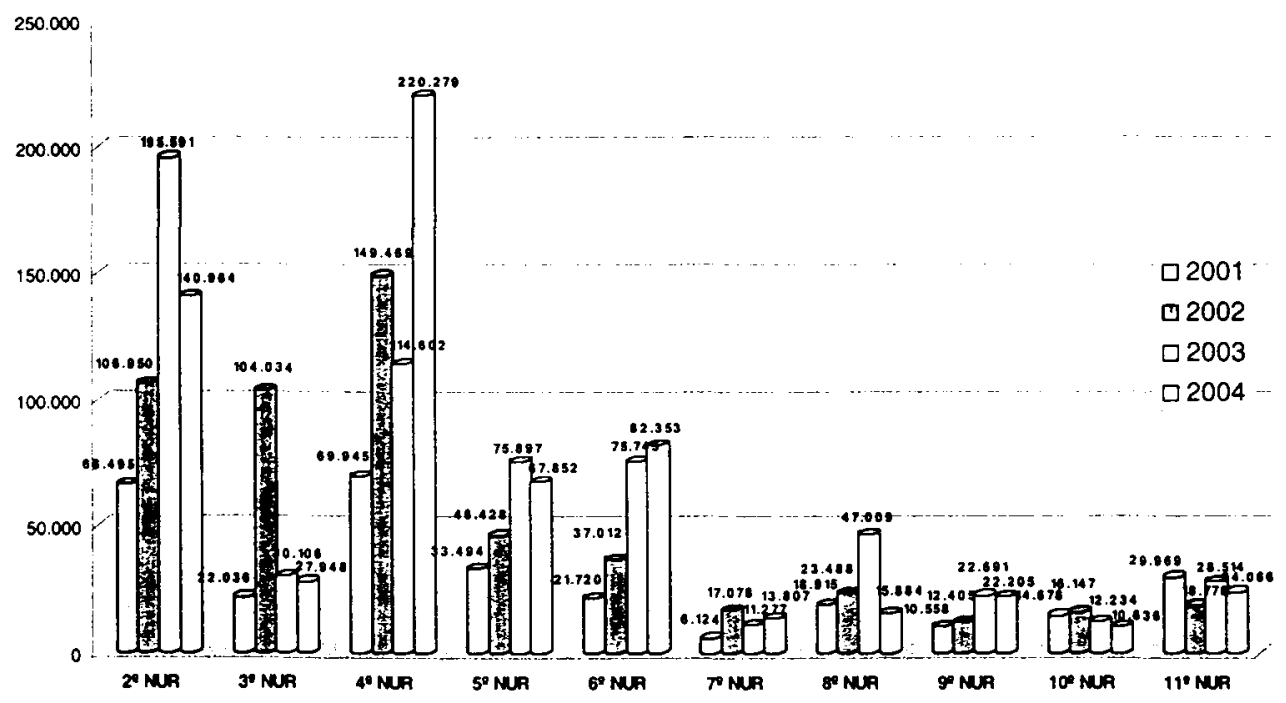

Mantendo a tendência geral, a contribuição dos $2^{\circ}$ e $4^{\circ}$ NUR responde por $51,53 \%$ do total de processos cíveis do Estado, entre 2001 e 2004, com exceção do $1^{\circ}$ NUR (Capital).

Ressalvadas algumas exceções $\left(3^{\circ}, 4^{\circ}, 7^{\circ}, 10^{\circ}\right.$ e $\left.11^{\circ} \mathrm{NUR}\right)$, a tendência é de elevação do volume de processos cíveis. Entre 2001 e 2002, o crescimento médio foi de $83 \%$; entre 2002 e 2003, de $15 \%$; entre 2003 e 2004, de $2,01 \%$; de 2001 a 2004 , acumulou-se o crescimento de $112,97 \%$. A brusca queda dos percentuais de crescimento no periodo $(83 \%, 15 \%$ e $2 \%)$ desafiaria pesquisa exploratória específica.

\section{Quadro 31: Total de processos criminais na $1^{\mathrm{a}}$ instância}

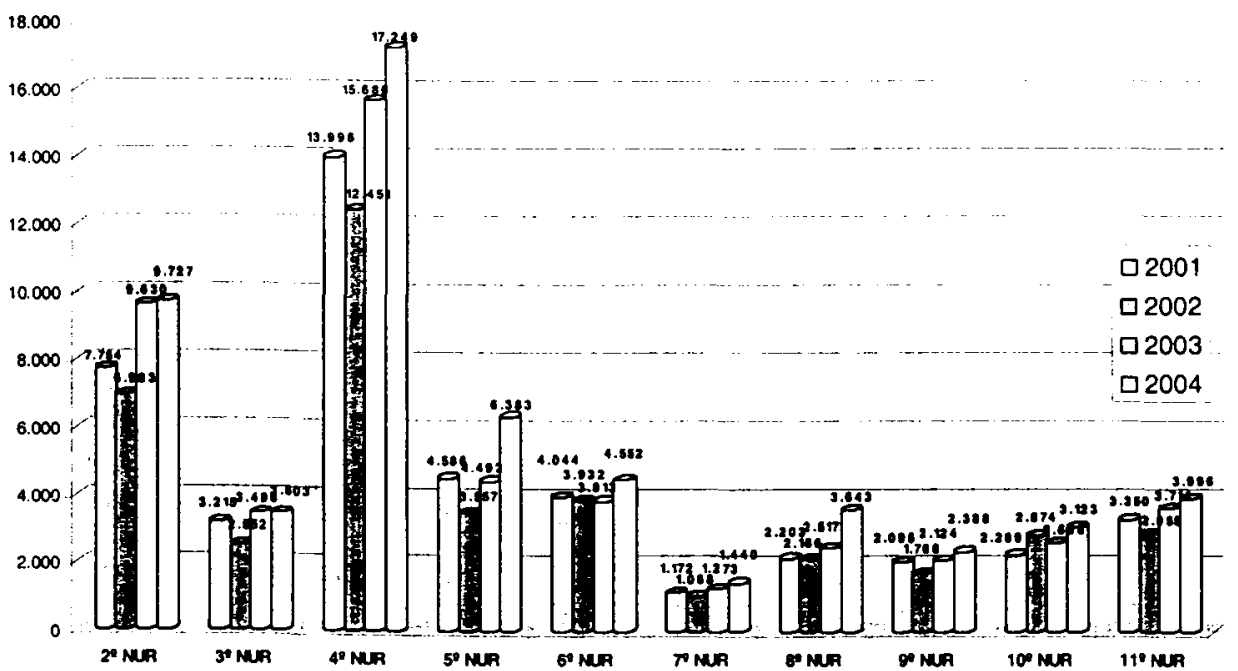


Em 2004 , os $2^{\circ}$ e $4^{\circ}$ NUR responderam por $69,48 \%$ do total de processos criminais do Estado, com exceção do $1^{\circ}$ NUR (Capital), evidenciando contribuição significativamente superior em relação aos processos cíveis, o que poderia estar associado aos bolsões de pobreza existentes na região compreendida por esses dois NUR.

Entre 2001 e 2002, houve redução de $10 \%$; entre 2002 e 2003, houve crescimento de $23 \%$; de 2001 a 2003 , crescimento médio de $11 \%$; crescimento de $13,11 \%$, entre 2003 e 2004.

\section{Quadro 32: Total de processos nos JEC e JECRIM}

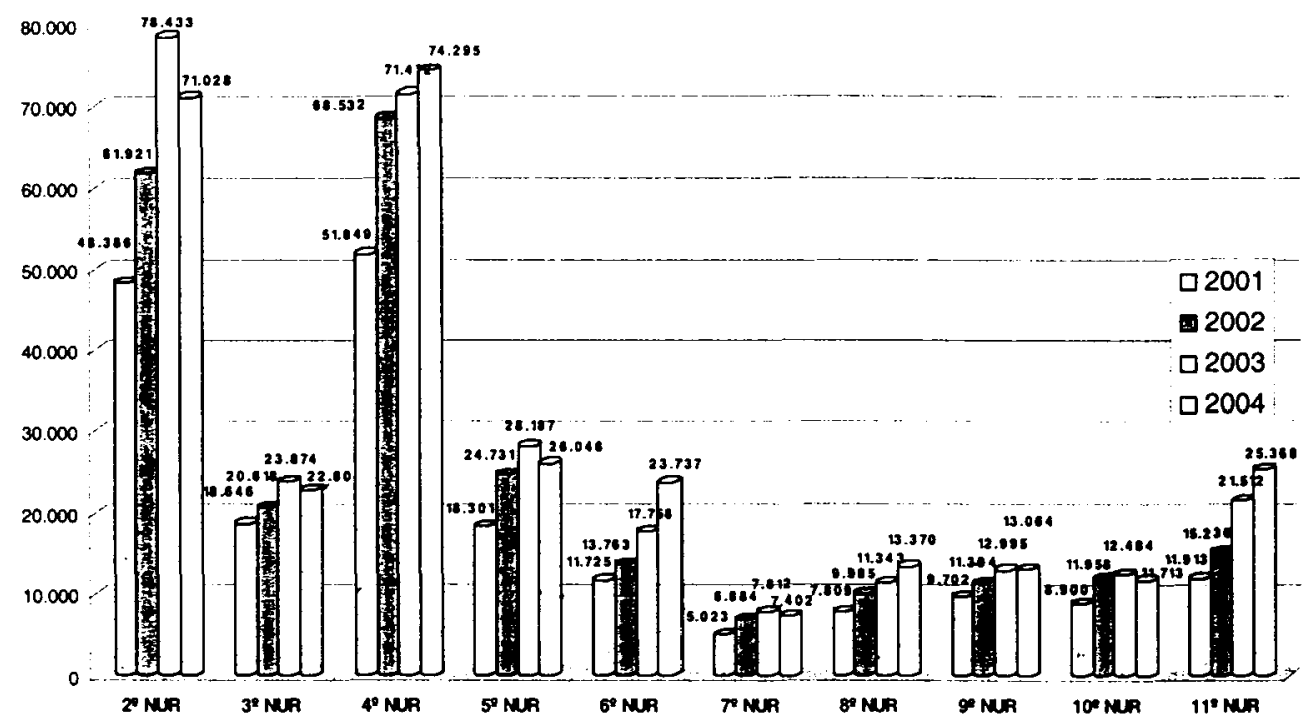

Mantendo a tendência geral, a contribuição dos $2^{\circ}$ e $4^{\circ}$ NUR responde por $51,97 \%$ do total de processos cíveis e criminais do Estado entre 2001 e 2004, com exceção do $1^{\circ}$ NUR (Capital).

A tendência, em todos os NUR, é de crescimento do volume de processos cíveis e criminais . Entre 2001 e 2002, o crescimento médio foi de $28 \%$; entre 2002 e 2003, 17\%; de 2001 a 2003, 50\%; entre 2003 e 2004, 1,03\%. A queda brusca no último intervalo do período desafiaria pesquisa exploratória específica. 


\section{Quadro 33: Total de processos cíveis nos JEC, por NUR}

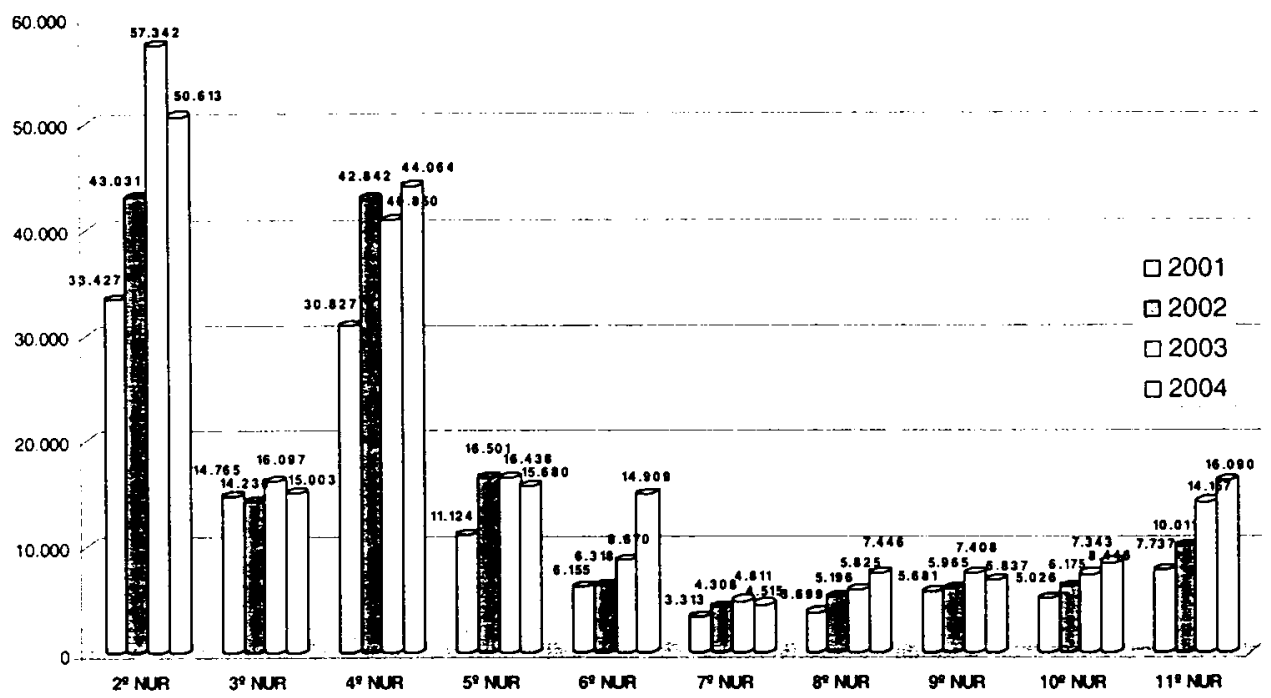

Mantendo a tendência geral, a contribuição dos $2^{\circ}$ e $4^{\circ}$ NUR responde por $53,69 \%$ do total de processos cíveis do Estado entre 2001 e 2004, com exceção do $1^{\circ}$ NUR (Capital).

Embora com algumas anomalias, a tendência geral, entre 2001 e 2004, é de crescimento do volume de processos cíveis. Entre 2001 e 2002, o crescimento médio foi de $26,94 \%$; entre 2002 e 2003, 15,76\% e, entre 2003 e 2004, 2,61\%. Novamente se apresenta queda acentuada no último intervalo do período, a desafiar pesquisa exploratória específica.

\section{Quadro 34: Total de processos nos JECRIM}

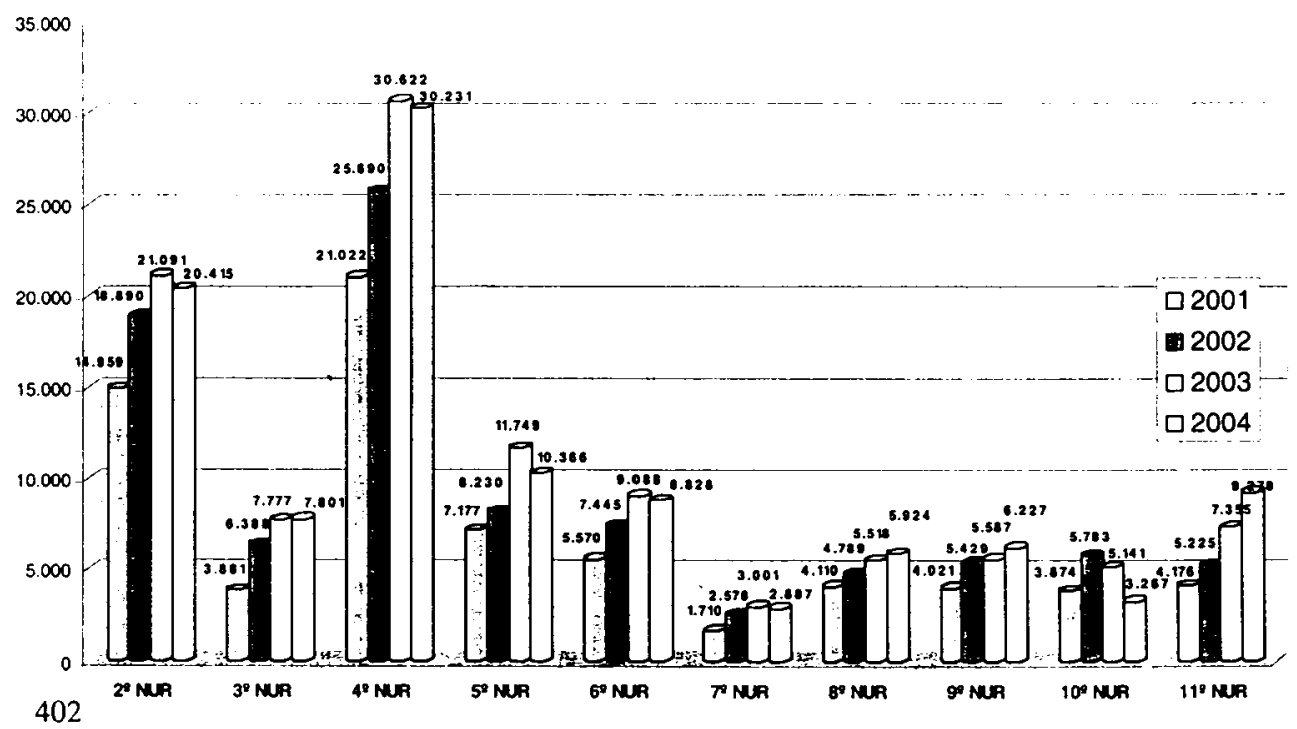


Mantendo a tendência geral, a contribuição dos $2^{\circ}$ e $4^{\circ}$ NUR responde por $49,03 \%$ do total de processos criminais do Estado entre 2001 e 2004, com exceção do $1^{\circ}$ NUR (Capital).

Ressalvado o $10^{\circ}$ NUR, observa-se tendência geral de crescimento em todos os NUR, quanto ao volume de processos criminais . Entre 2001 e 2002, o crescimento médio foi de $28,29 \%$; entre 2002 e 2003 , houve crescimento de $18,23 \%$; e entre 2003 a 2004, houve redução de 1,59\%. A inversão da tendência no último intervalo do período demandaria pesquisa exploratória específica.

\section{Quadro 35 - Total de processos, cíveis e criminais, nas Turmas Recursais}

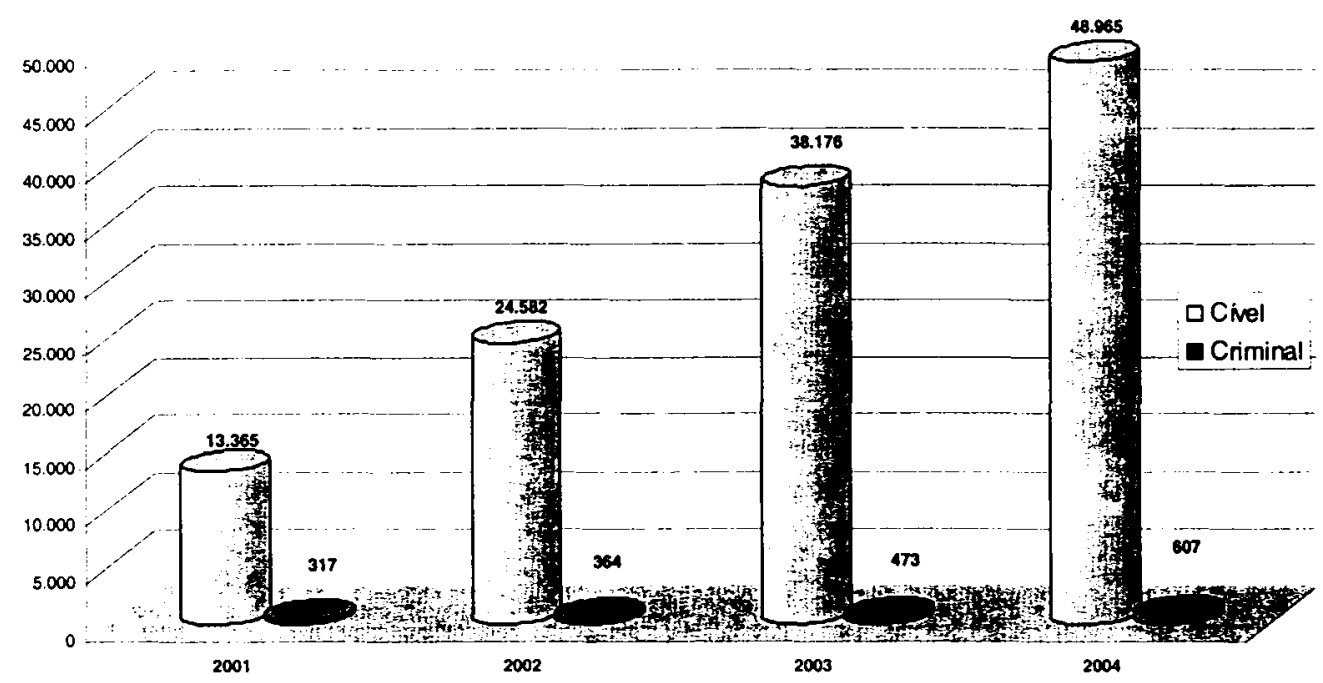

Observa-se tendência geral de crescimento no volume de processos cíveis e criminais geradores de recursos, oriundos dos Juizados Especiais. Totalizaram 77.277 entre 2001 e 2003. Desse total, 1,50\% corresponderam a processos criminais (1.154) e $98,50 \%(76.123)$ a processos cíveis.

Com relação aos processos cíveis, entre 2001 e 2002 o crescimento médio foi de $84 \%$; entre 2002 e 2003, houve crescimento de 55\%; entre 2003 e 2004, houve crescimento de $28,26 \%$; de 2001 a $2004,266,36 \%$.

Com relação a processos criminais, entre 2001 e 2002 o crescimento médio foi de 15\%; entre 2002 e 2003 houve crescimento de 30\%; entre 2003 e 2004 houve crescimento de $28,32 \%$; de 2001 a 2004 , crescimento de $91,48 \%$, indicando variação substancialmente menor em relação aos processos cíveis. 


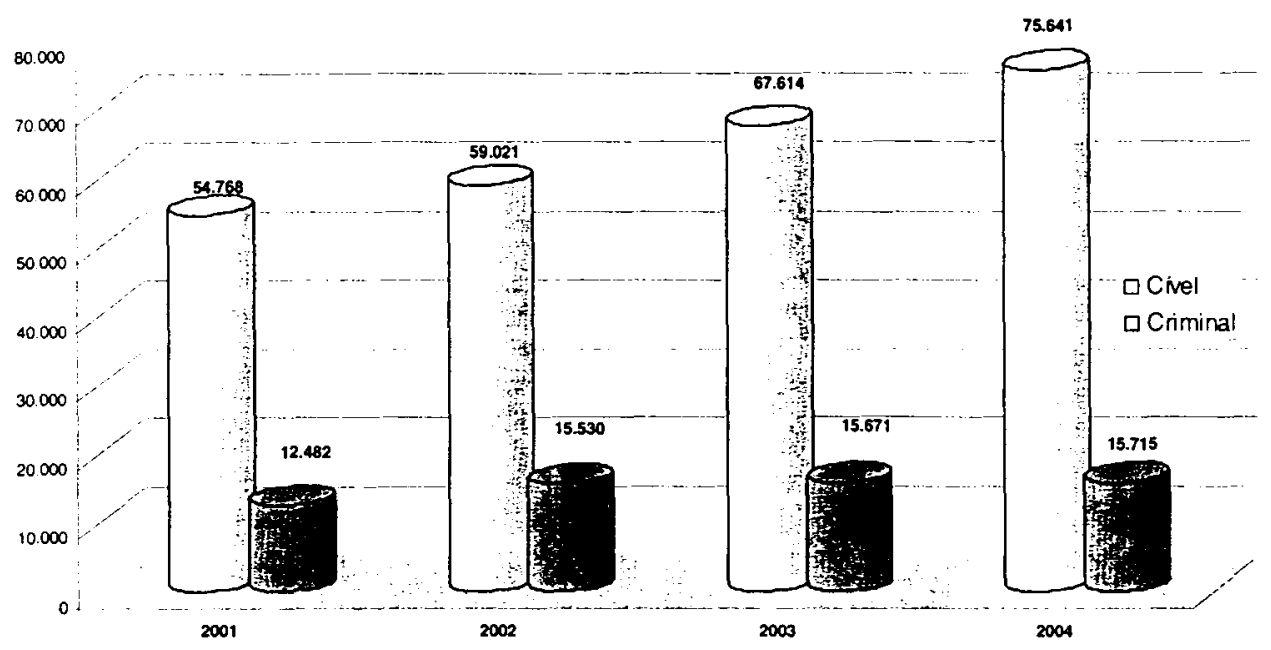

Observa-se tendência geral de crescimento no volume de processos cíveis e criminais geradores de recursos, oriundos das Varas. Totalizaram 316.432, entre 2001 e 2004. Desse total, $18,77 \%$ corresponderam a processos criminais (59.398); $81,23 \%$ (257.034) a processo cíveis.

Com relação a processos cíveis, entre 2001 e 2002 o crescimento foi de $7,8 \%$; entre 2002 e 2003, de 14,6\%; entre 2003 e 2004, de $11,87 \%$.

Com relação aos processos criminais, entre 2001 e 2002 o crescimento médio foi de $24,4 \%$; entre 2002 e 2003 , de $1,0 \%$; entre 2003 e 2004 , de $0.28 \%$.

A ascensão do volume de processos cíveis é tão nítida quanto o declínio do volume de processos criminais na segunda instância, a inspirar possível reestudo sobre a proporcionalidade entre o número de Câmaras Cíveis e o de Câmaras Criminais.

\section{Indicadores de habitantes por processo em Juizados Especiais}

As análises atinentes aos Quadros 37, 38, 39 e 40, a seguir, foram realizadas com base apenas no ano de 2003 , tendo em vista tratar-se de ano que melhor corresponde ao perfil médio da prestação jurisidicional. 


\section{Quadro 37: Habitante por processo cível (em 2003)}

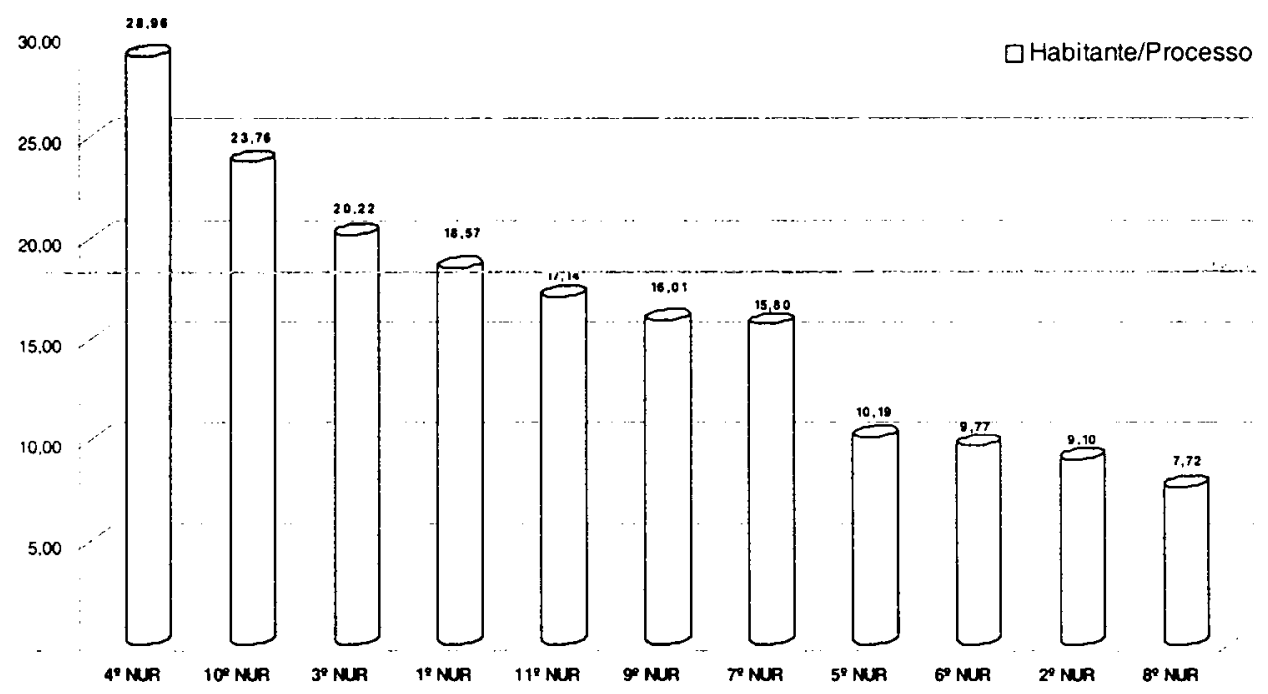

Um valor muito alto de habitantes por processo poderia representar baixa demanda da sociedade ou baixa oferta da jurisdição, decorrente do desestímulo à busca pela Justiça em função do provável congestionamento dos órgãos judicantes. Um valor baixo de habitantes por processo poderia significar alta demanda por ações. Em qualquer caso, parece apropriado definir, a partir de medições e avaliações, o padrão ideal de habitantes por processo e equipar os órgãos judiciais para atendê-lo.

A média obtida é de 16,11 habitantes por processo: de modo aproximado, de cada 16 pessoas, uma gera um processo judicial cível. O desvio padrão ${ }^{10}$ desse indicador, 7, mostrou-se elevado, apontando grande variabilidade entre os NUR, com relação a essa variável.

No $4^{\circ}$ NUR (Baixada Fluminense), segunda população do Estado (3.318.823 habitantes), a média, em 2003, foi de 28,98 habitantes por processo, a sugerir o concurso de dois fatores: condição sócio-econômica da população e/ou descrédito na justiça estatal como via de resolução dos conflitos, fazendo supor que a população conta com outros canais de composição, não-estatais ou informais.

10 O desvio padrão é uma medida da dispersão dos valores de uma população ou amostra em relação à sua média. Em outras palavras, o desvio padrão mede o grau de heterogeneidade da população ou da amostra, sendo calculado pela seguinte fórmula: .

O Coeficiente de Variação, calculado mediante comparação porcentual entre o valor do desvio padrão e a média, é neste caso de $43 \%$, indicando grande variabilidade ou grau de variação das medidas em relação à média. Nos processos industriais, usualmente mais precisos, aceitam-se, como praxe, Coeficientes de Variação inferiores a $1 \%$; no caso do Indicador em análise, o valor obtido de $43 \%$ representa, por comparação, relevante disparidade entre as medidas. 


\section{Quadro 38: Habitante por processo criminal (em 2003)}

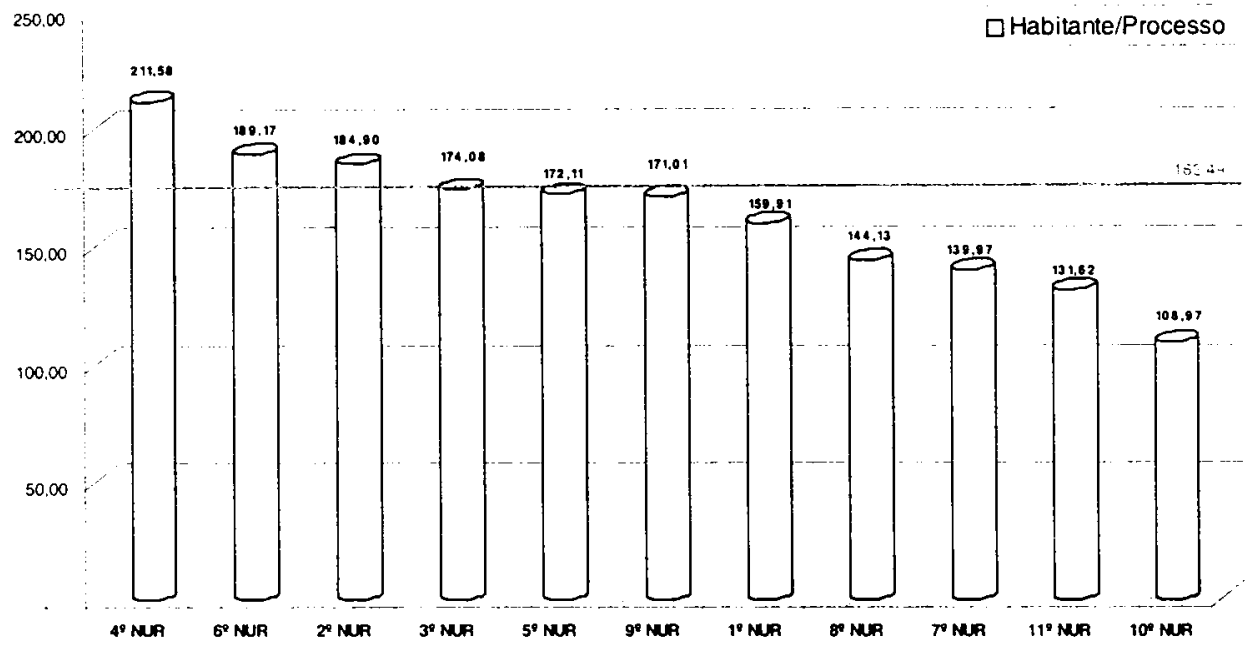

A média é de 162,49 habitantes por processo: a cada 162 pessoas, uma gera um processo judicial criminal. O desvio padrão é de 27,entre os NUR.

No $4^{\circ}$ NUR (Baixada Fluminense), segunda população do Estado (3.318.823 habitantes), a média, em 2003, foi de 211,68 habitantes por processo criminal, a sugerir a presença de focos menos concentrados de fatores criminogênicos, o que surpreenderia a imagem estereotipada da Baixada Fluninense, como região sujeita a maiores índices de criminalidade. Ou, alternativamente, que, tal como nos processos cíveis, a população faz uso de vias não-estatais de composição ou contenção de conflitos.

Quadro 39: Habitante por processo em Juizados Especiais Cíveis (em 2003)

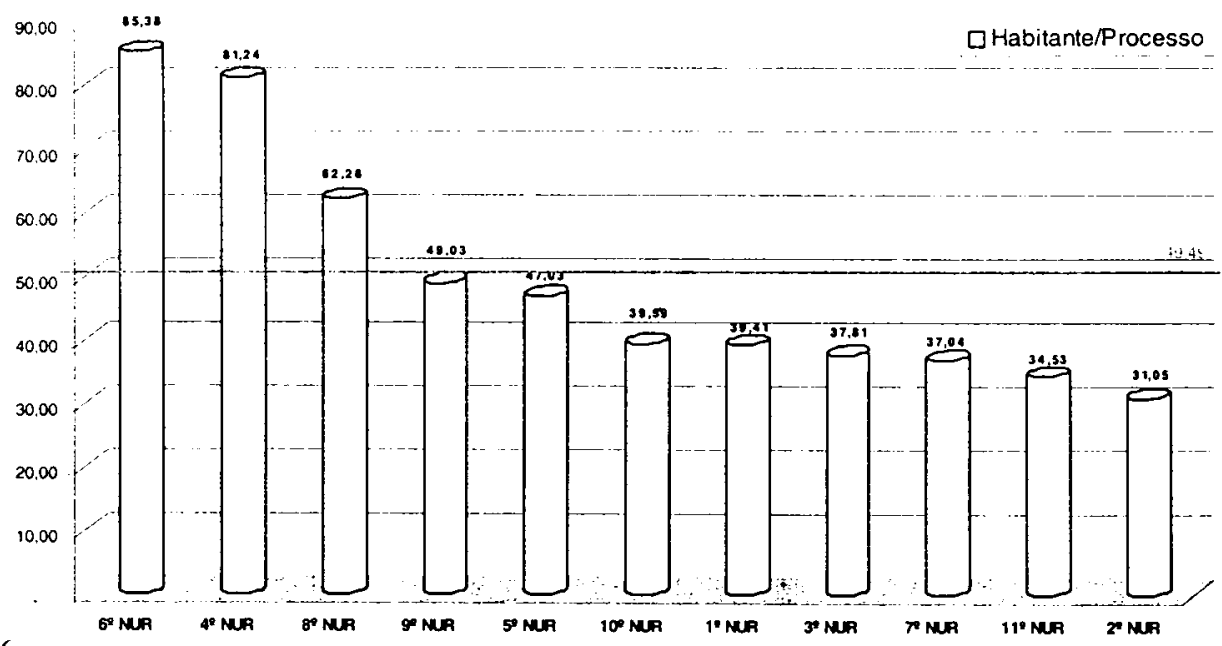


A média é de 49,49 habitantes por processo: a cada 50 pessoas, uma gera um processo judicial cível, de valor até 40 salários mínimos. O desvio padrão é de 18 , entre os NUR.

No $4^{\circ}$ NUR (Baixada Fluminense), segunda população do Estado (3.318.823 habitantes), a média, em 2003, foi de 81,24 habitantes por processo.

\section{Quadro 40: Habitante por processo em Juizados Especiais Criminais} (em 2003)

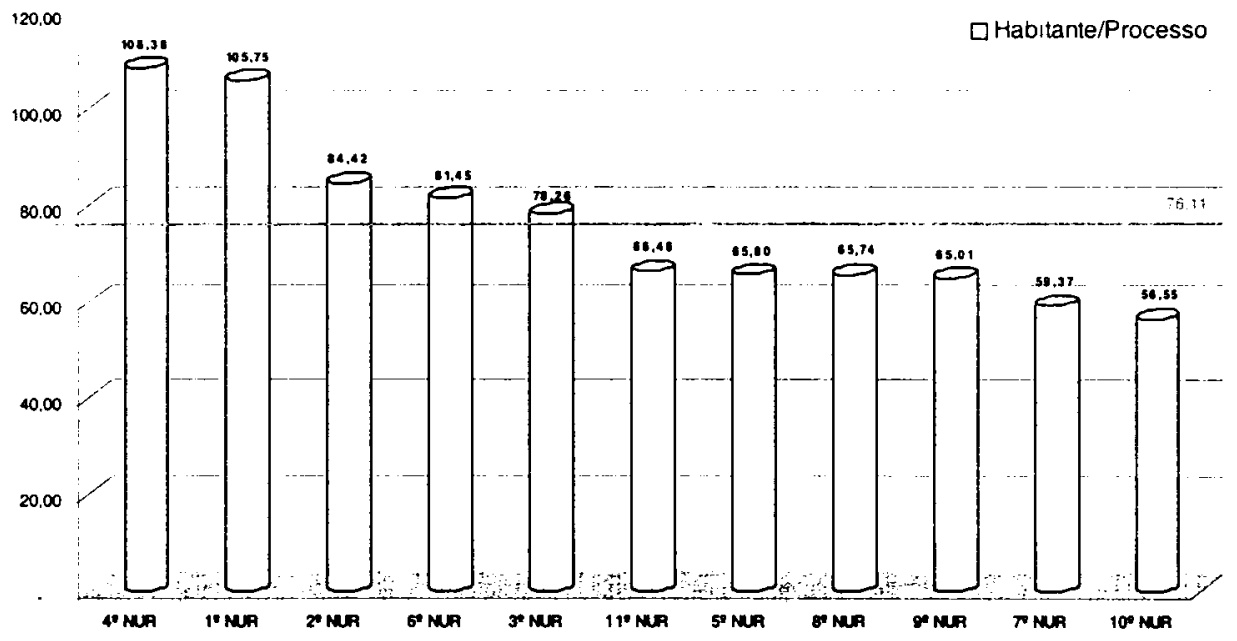

A média é de 76,11 habitantes por processo: a cada 76 pessoas, uma gera um processo judicial criminal por delito de menor potencial lesivo (como próprio da competência desses Juizados). O desvio padrão é de 18, entre os NUR.

No $4^{\circ}$ NUR (Baixada Fluminense), segunda população do Estado (3.318.823 habitantes), a média, em 2003, foi de 108 habitantes por processo judicial criminal.

10.4 Indicador de carga de trabalho $(\hat{E})$

O Indicador:

a) considerou todo o conjunto de processos e de magistrados;

b) não excluiu os juízes em funções administrativas, a exemplo dos juízes auxiliares da Presidência, da Corregedoria Geral da Justiça e dos Vice-Presidentes;

c) considerou a totalidade do quadro atual de 160 desembargadores;

d) distinguiu as situações:

- carga de trabalho de juízes;

- carga de trabalho de desembargadores. 


\begin{tabular}{|c|c|}
\hline Fórmula & $K=(C P+C l) / M_{a g}$ \\
\hline \multicolumn{2}{|l|}{ Legenda: } \\
\hline \multicolumn{2}{|c|}{$\begin{array}{l}\text { CP = Casos pendentes (saldo de processos do periodo anterior, tombados e não } \\
\text { julgados) }\end{array}$} \\
\hline \multicolumn{2}{|c|}{$\mathrm{Cl}=$ Casos iniciais (processos tombados) } \\
\hline $\mathbf{M}_{\mathrm{ag}}=$ número de magistrados & \\
\hline
\end{tabular}

\section{Quadro 41 - Carga de trabalho}

\begin{tabular}{|c|c|c|c|c|}
\hline $1^{\text {a }}$ Instância + Juizados & 2001 & 2002 & 2003 & 2004 \\
\hline $\mathrm{CP}$ & 2.923 .586 & 3.193 .773 & 3.697 .171 & 4.268 .835 \\
\hline $\mathrm{Cl}$ & 912.229 & 1.256 .141 & 1.516 .240 & 1.548 .415 \\
\hline Magistrados (juizes) & 574 & 586 & 627 & 646 \\
\hline$K$ & 6683 & 7594 & 8315 & 9005 \\
\hline
\end{tabular}

\begin{tabular}{|c|c|c|c|c|}
\hline $2^{\mathrm{a}}$ Instância & 2001 & 2002 & 2003 & 2004 \\
\hline $\mathrm{CP}$ & 5.600 & 15.936 & 15.100 & 24.424 \\
\hline $\mathrm{Cl}$ & 67.250 & 74.551 & 83.285 & 91.356 \\
\hline Magistrados (desembargadores) & 160 & 160 & 160 & 160 \\
\hline $\mathrm{K}$ & 455 & 566 & 615 & 724 \\
\hline
\end{tabular}

\section{Análise parcial:}

Os dados referentes a casos pendentes (CP) em cada ano dizem respeito ao acervo de processos judiciais existentes no primeiro dia do ano. Os casos iniciais (CI) dizem respeito a todo o acervo recebido ao longo do ano considerado.

O Indicador $\hat{E}$ (carga de trabalho) retrata:

a) com relação aos juízes, que:

- no ano de 2001 , a carga média de trabalho era de 6.683 processos por juiz; em 2002, de 7.594 processos por juiz; em 2003, de 8.315 processos por juiz; em 2004, 9.005 processos por juiz; houve aumento de $34,74 \%$ da carga média de trabalho, entre 2001 e 2004 ;

b) com relação aos desembargadores, que:

- no ano de 2001 , a carga média de trabalho era de 455 processos por desembargador; em 2002, de 566 processos por desembargador; em 2003, de 615 processos por desembargador; em 2004 , de 724 processos por desembargador; houve aumento de $59,12 \%$ da carga média de trabalho entre 2001 e 2004 , resultante da provável combinação da estabilidade do número de desembargadores (160), do aumento do número de casos iniciais $(35,85 \%)$ e do aumento de casos pendentes $(336,14 \%)$; observe-se que o valor de casos pendentes no ano de 2001 (5.600) discrepa do 
conjunto (na verificação realizada, houve confirmação do valor fornecido pelo Sistema JUD); tal fato, associado às bruscas quedas de percentuais, sinalizadas nas análises dos Quadros 28 a 32, retro, obriga a que se cogite de problemas na geração de dados referentes ao primeiro intervalo do quadriênio (2001-2002), o que, todavia, não desfigura o cenário atual.

Considerando-se que cada decisão judicial terminativa (sentença ou acórdão) é proferida em texto com a extensão média de 90 (noventa) linhas (60 caracteres por linha, 5.400 caracteres por decisão), verifica-se que:

- cada juiz, ao proferir, por ano, a média de 500 sentenças, escreve textos com o total de 2.700.000 caracteres, o que corresponde a cinco livros de trezentas páginas ( 544.500 caracteres por livro);

- cada desembargador, ao relatar, por ano, a média de 600 acórdãos, escreve textos com total de 3.240 .000 caracteres, o que corresponde a seis livros de trezentas páginas.

Ainda que se descontem desses números arredondados os textos referentes a questões que se repetem no cotidiano forense, ensejando a adaptação de textos padronizados, a equiparação da redação de decisões judiciais à redação de livros traduz, com melhor visibilidade para o público, a carga de trabalho de um magistrado fluminense a cada ano. em termos de textos produzidos, sem contar o tempo dedicado ao estudo dos autos, bem como à condução de audiências e sessões de julgamento.

A medida do tempo na carga de trabalho do magistrado, como indicador de eficiência e produtividade. depende de variáveis cuja configuração objetiva em padrões médios é complexa. Recomenda-se a busca de mais indicadores de desempenho, mediante a inscrição nas estatísticas de, entre outros, dados pertinentes a número de depoimentos colhidos, de despachos e decisões interlocutórias prolatados, de dias em que os autos permanecem conclusos para exame, de decisões terminativas proferidas em audiência ou em julgamento antecipado.

Esses dados decerto que oscilarão em razão das matérias de competência do órgão jurisidicional em que atue o magistrado. Em Varas Criminais, Cíveis ou de Família, por exemplo, as audiências de partes e testemunhas são indispensáveis em grande número, para o fim de apurar fatos e circunstâncias controvertidos, ao contrário do que ocorre em Varas de Fazenda Pública. Sucessões ou Registros Públicos, onde os conflitos versam temas em sua maioria exclusivamente técnicos, cuja compreensão independe, salvo nos casos de responsabilização civil do Estado, da produção de provas (orais ou periciais).

Também a personalidade, o temperamento e a experiência pessoais do magistrado influem no processo de formação de seu convencimento e, portanto, sobre o

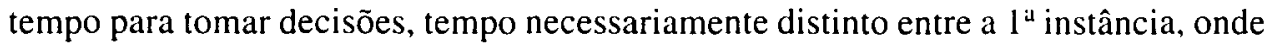
o juiz colhe a prova e modela a solução para o conflito, e o segundo grau, onde o desembargador verifica o acerto ou o desacerto da solução encontrada, somente por exceção refazendo a prova.

De toda sorte, a percepção que se tem é a de que, em média, o magistrado fluminense necessita de 60 horas semanais de trabalho para manter em ordem e sob prazos aceitáveis o serviço a seu cargo, podendo essa jornada estender-se por mais de 80 horas semanais nos órgãos sujeitos a maior pressão de demanda, nas comarcas 
e foros de maior porte, ou reduzir-se para 30-40 horas semanais nas comarcas e foros de menor movimento. Essa é a lógica que preside o escalonamento das comarcas em três entrâncias, observado o grau crescente de volume e de complexidade da demanda: primeira entrância, com 43 comarcas instaladas; segunda entrância, com 31 comarcas instaladas; e entrância especial, com 9 comarcas instaladas. Em razão dessa desigual carga de trabalho entre as entrâncias, seria o caso de considerar-se a oportunidade de um reestudo sobre os critérios de classificação e distribuição de comarcas e juízes entre as entrâncias.

\subsection{Indicador de congestionamento $(\tilde{A})$}

Distinguiram-se duas situações:

- congestionamento por juízes;

- congestionamento por desembargadores.

\begin{tabular}{|l|l|}
\hline \multicolumn{1}{|c|}{ Fórmula } & $\Gamma=(C P+C I) / D$ \\
\hline Legenda: \\
$C P=$ casos pendentes \\
$C l=$ casos iniciais \\
$D=$ número de processos julgados (por juiz ou por desembargador) \\
\hline
\end{tabular}

\section{Quadro 42 - Indicador de congestionamento}

\begin{tabular}{|c|r|r|r|r|}
\hline 1 Instância + Juizados & \multicolumn{1}{c|}{2001} & \multicolumn{1}{c|}{2002} & \multicolumn{1}{c|}{2003} & \multicolumn{1}{c|}{2004} \\
\hline $\mathrm{CP}$ & 2.923 .586 & 3.193 .773 & 3.697 .171 & 4.268 .835 \\
\hline $\mathrm{Cl}$ & 912.229 & 1.256 .141 & 1.516 .240 & 1.548 .415 \\
\hline Processos Julgados & 543.745 & 654.609 & 717.104 & 732.035 \\
\hline & 7.05 & 6,80 & 7,27 & 7,95 \\
\hline
\end{tabular}

\begin{tabular}{|c|r|r|r|r|}
\hline $2^{2}$ Instância & \multicolumn{1}{|c|}{2001} & \multicolumn{1}{c|}{2002} & \multicolumn{1}{c|}{2003} & \multicolumn{1}{c|}{$\mathbf{2 0 0 4}$} \\
\hline $\mathrm{CP}$ & 5.600 & 15.936 & 15.100 & 24.424 \\
\hline $\mathrm{Cl}$ & 67.250 & 74.551 & 83.285 & $\mathbf{9 1 . 3 5 6}$ \\
\hline Processos Julgados & 65.715 & 78.958 & 83.498 & 86.842 \\
\hline & 1,11 & 1,15 & 1,18 & 1,33 \\
\hline
\end{tabular}

\section{Análise parcial:}

A análise dos dados, em ambas as instâncias, denota atipicidade nos dados pertinentes ao ano de 2002, que pode ser explicado por inconsistências decorrentes da transição entre coleta manual (realizada mediante transferência de arquivos) e coleta automatizada (realizada mediante sistemas). Essa atipicidade, em que pese comprometer a precisão das informações, preserva-lhes as tendências.

Em ambas as instâncias observam-se taxas negativas de crescimento, tanto de casos iniciais quanto de julgamentos. Todavia, a primeira taxa desacelara-se mais 
lentamente que a segunda, decorrendo crescimento do indicador de taxa de congestionamento nos $1^{\circ}$ e $2^{\circ}$ graus.

Com relação ao $1^{\circ}$ grau, o indicador de taxa de congestionamento retrata:

??no ano de 2001 , a taxa de congestionamento era de 7,05 (em cada 8 processos, 1 era julgado); em 2002, de 6,80; em 2003, de 7,27; em 2004, de 7,95; tais números denotam tendência crescente de congestionamento, com acúmulo adicional, em 2004 , de 17.244 processos não-julgados, que se somam aos casos pendentes do período anterior;

Com relação ao $2^{\circ}$ grau, o indicador de taxa de congestionamento retrata:

??no ano de 2001, a taxa de congestionamento era de 1,11; em 2002, de 1,15; em 2003, 1,18; em 2004, de 1,33; tais números denotam tendência crescente de congestionamento, com acúmulo adicional, em 2004, de 4.727 processos não-julgados, que se somam aos casos pendentes do período anterior.

Resulta evidenciado que há congestionamento a taxas crescentes em ambas as instâncias (média anual de 7,23 no $1^{\circ}$ grau, e de 1,19 no $2^{\circ}$ grau de jurisdição), mas que o índice de congestionamento na primeira instância é seis vezes o índice de congestionamento na segunda, a fortemente recomendar providências de maior apoio ao primeiro grau (Varas e Juizados), com vistas à progressiva redução de sua taxa de congestionamento. Novamente o recurso à figura do juiz leigo se oferece como alternativa a ser considerada, ao lado de maior automação de procedimentos judiciais e racionalização de rotinas cartorárias, tais como aquelas que advêm da adoção do padrão ISO 9001:2000, posto em prática na $13^{\mathrm{a}}$ Vara Cível (Comarca da Capital) a partir de 2004.

\subsection{Indicador de recorribilidade dos Juizados Especiais às Turmas Recursais} (Juizados)

\begin{tabular}{|l|l|}
\hline \multicolumn{1}{|c|}{ Fórmula } & $\tau_{\text {Juizados }}=R_{T \text { Thoc }} / D_{\text {Juzadose }}$ \\
\hline Legenda: \\
$R_{T R_{\infty}=\text { Recursos dos Juizados às Turmas Recursais }}$ \\
$D_{V}=$ Total de decisōes nos Juizados \\
\hline
\end{tabular}

\section{Quadro 43 - Indicador de recorribilidade dos Juizados Especiais às Turmas Recursais}

\begin{tabular}{|c|c|c|c|c|c|c|c|c|c|c|c|c|}
\hline \multirow{2}{*}{$\begin{array}{l}\text { Julzedos } \\
\text { Eepeciais } x \\
\text { Turmas } \\
\text { Recurseis }\end{array}$} & \multicolumn{3}{|c|}{2001} & \multicolumn{3}{|c|}{2002} & \multicolumn{3}{|c|}{2003} & \multicolumn{3}{|c|}{2004} \\
\hline & $\begin{array}{l}\text { Julzados } \\
\text { Espociais }\end{array}$ & $\begin{array}{c}\text { Turmas } \\
\text { Recursais }\end{array}$ & Taxa & $\begin{array}{l}\text { Julzados } \\
\text { Especiais }\end{array}$ & $\begin{array}{l}\text { Turmas } \\
\text { Recursais }\end{array}$ & $\operatorname{Tax} 2$ & $\begin{array}{l}\text { Julzados } \\
\text { Especiais }\end{array}$ & $\begin{array}{c}\text { Turmas } \\
\text { Recursais }\end{array}$ & Taxa & $\begin{array}{l}\text { Juizados } \\
\text { Especiais }\end{array}$ & $\begin{array}{c}\text { Turmas } \\
\text { Recurasia }\end{array}$ & Taxa \\
\hline Civel & 179.218 & 13.365 & $7,46 \%$ & 254.727 & 24.582 & $9,65 \%$ & 293.574 & 38.176 & $13,00 \%$ & 333.823 & 48.965 & $14,67 \%$ \\
\hline Criminal & 50.089 & 317 & $0,63 \%$ & 52.084 & 364 & $0.70 \%$ & 60.949 & 473 & $0,78 \%$ & 54.454 & 607 & $1.11 \%$ \\
\hline Geral & 229.307 & 13.682 & $5,97 \%$ & 306.811 & 24.946 & $8,13 \%$ & 354.523 & 38.649 & $10,90 \%$ & 388.277 & 49.572 & $12,77 \%$ \\
\hline
\end{tabular}

\section{Análise Parcial:}

O indicador diz respeito, em termos porcentuais, à proporção de recursos às Turmas Recursais nos processos julgados nos Juizados Especiais. A análise consi- 
derou a separação em processos cíveis e criminais em face da diferença entre eles, de ordem de grandeza. O indicador retrata:

a) em relação a processos cíveis:

$\mathrm{O}$ indicador, que em 2004 apresentou o valor de 14,67\%, tem crescido continuamente desde 2001 (7,46\%). Vale dizer que, em média, entre 2001 e 2004, para cada 100 processos julgados, em cerca de 11 deles houve interposição de recursos. Depreende-se que, em que pese ser o valor nominal do indicador relativamente baixo (média de 11,20\%), mostra crescimento contínuo, à taxa média de $25,64 \%$ ao ano;

b) em relação a processos criminais:

$\mathrm{O}$ indicador de recursos em processos criminais é cerca de treze vezes menor do que o correspondente a processos cíveis, com média de $0,81 \%$ entre 2001 e 2004 . Vale dizer que em cada 100 processos há recurso em menos de um. Mas também aqui observa-se crescimento contínuo do valor do indicador, com média de crescimento de $21,62 \%$ ao ano, puxada pelo aumento de recursos interpostos no ano de $2004(1,11 \%)$. A significativa diferença entre a recorribilidade nos processos cíveis e criminais pode ser explicada pelo fato de, não havendo perspectiva de privação de liberdade nos últimos (crimes de baixo potencial ofensivo), as penas alternativas provavelmente causem menos desconforto do que as condenações em processos cíveis, que implicam pecúnia, a "parte mais sensível do ser humano - o bolso".

10.7 Indicador de recorribilidade das Varas ao segundo grau de jurisdição (seg)

\begin{tabular}{|l|l|}
\hline \multicolumn{1}{|c|}{ Fórmula } & $\tau_{\text {Seg }}=R_{\text {Seg }} / D_{V}$ \\
\hline Legenda: & \\
$R_{\text {seg }}=$ Recursos ao segundo grau & \\
$D_{V}=$ Total de decisões nas Varas & \\
\hline
\end{tabular}

\section{Quadro 44 - Indicador de recorribilidade das Varas ao segundo grau}

\begin{tabular}{|c|c|c|c|c|c|c|c|c|c|c|c|c|}
\hline \multirow[b]{2}{*}{$\begin{array}{c}1^{*} \text { Instâncle } \times 2 \\
\text { Inståncla }\end{array}$} & \multicolumn{3}{|c|}{2001} & \multicolumn{3}{|c|}{2002} & \multicolumn{3}{|c|}{2003} & \multicolumn{3}{|c|}{2004} \\
\hline & $\begin{array}{c}\text { Julgados } \\
10 \\
\text { Instância }\end{array}$ & $\begin{array}{c}\text { Recursos } \\
24 \\
\text { Instáncia }\end{array}$ & Taxa & $\begin{array}{c}\text { Julgados } \\
10 \\
\text { Instâncla }\end{array}$ & $\begin{array}{c}\text { Recursos } \\
24 \\
\text { Instáncla }\end{array}$ & Taxa & $\begin{array}{c}\text { Julgados } \\
10 \\
\text { Instância }\end{array}$ & $\begin{array}{c}\text { Recursos } \\
2^{\prime} \\
\text { Inståncia }\end{array}$ & Taxe & $\begin{array}{c}\text { Julgados } \\
1 * \\
\text { Instáncla }\end{array}$ & \begin{tabular}{|c|} 
Recursos \\
24 \\
Instàncla
\end{tabular} & Taxa \\
\hline Civel & 271.397 & 54.768 & $20.18 \%$ & 303.750 & 59.021 & $19.43 \%$ & 322.065 & 67.614 & $20,99 \%$ & 308.994 & \begin{tabular}{|l|}
75.641 \\
\end{tabular} & $24,48 \%$ \\
\hline Criminal & 43.041 & 12.482 & $29.00 \%$ & 44.048 & 15.530 & $35.26 \%$ & 40.516 & 15.671 & $38.68 \%$ & 34.764 & 15.715 & $45,20 \%$ \\
\hline Geral & 314.438 & 67.250 & $21.39 \%$ & 347.798 & 74.551 & $21,44 \%$ & 362.581 & 83.285 & $22.97 \%$ & 343.758 & 91.356 & $26.58 \%$ \\
\hline
\end{tabular}

\section{Análise Parcial:}

$O$ indicador retrata o conjunto de recursos ao segundo grau, interpostos das sentenças prolatadas nas Varas, sendo expresso em termos porcentuais. A análise considerou a separação de processos cíveis e de criminais em face da significativa diferença entre eles. $\mathrm{O}$ indicador retrata:

a) em relação a processos cíveis: 
Observa-se relativa estabilidade do indicador no período, com média de $21,27 \%$. Vale dizer que em cada 100 processos, cerca de 21 recebem recursos interpostos ao segundo grau;

b) em relação a processos criminais:

Inverte-se aqui a tendência observada nos Juizados Especiais: a taxa de recorribilidade em processos criminais é quase o dobro da correspondente em processos cíveis. $O$ fato pode ser explicado pela perspectiva, em geral presente, de privação de liberdade, associada às possibilidades econômicas de quem recorre. A média de recorribilidade foi de $37,04 \%$, também estando presente crescimento contínuo no período, com aumento expressivo em 2004 , cuja taxa foi de $45,20 \%$, indicando que de cada 100 processos, 45 recebem recurso ao segundo grau.

10.8 Indicador de recorribilidade interna no segundo grau (in)

\begin{tabular}{|l|l|}
\multicolumn{1}{|c|}{ Fórmula } & $\tau_{\text {int }}=R_{\text {int }} / \mathbf{D}_{\text {Seg }}$ \\
\hline Legenda: & \\
$R_{\text {int }}=$ Recursos internos \\
$D_{\text {Sog }}=$ Total de decisões no segundo grau \\
\hline
\end{tabular}

Quadro 45 - Indicador de recorribilidade interna no segundo grau

\begin{tabular}{|r|c|c|c|c|}
\hline \multirow{2}{*}{$\begin{array}{c}\text { Indicadores de Recursos } \\
\text { Internos }\end{array}$} & \multicolumn{4}{|c|}{ Quantidade/Ano } \\
\cline { 2 - 5 } & $\mathbf{2 0 0 1}$ & $\mathbf{2 0 0 2}$ & $\mathbf{2 0 0 3}$ & $\mathbf{2 0 0 4}$ \\
\hline Recursos Internos & 15.650 & 21.142 & 23.404 & 24.188 \\
\hline Decisões & 79.213 & 98.068 & 104.444 & 107.447 \\
\hline Taxa de Recurso Interno & $19,76 \%$ & $\mathbf{2 1 , 5 6 \%}$ & $22,41 \%$ & $\mathbf{2 2 , 5 1 \%}$ \\
\hline
\end{tabular}

Quadro 45.1 - Evolução temporal do indicador

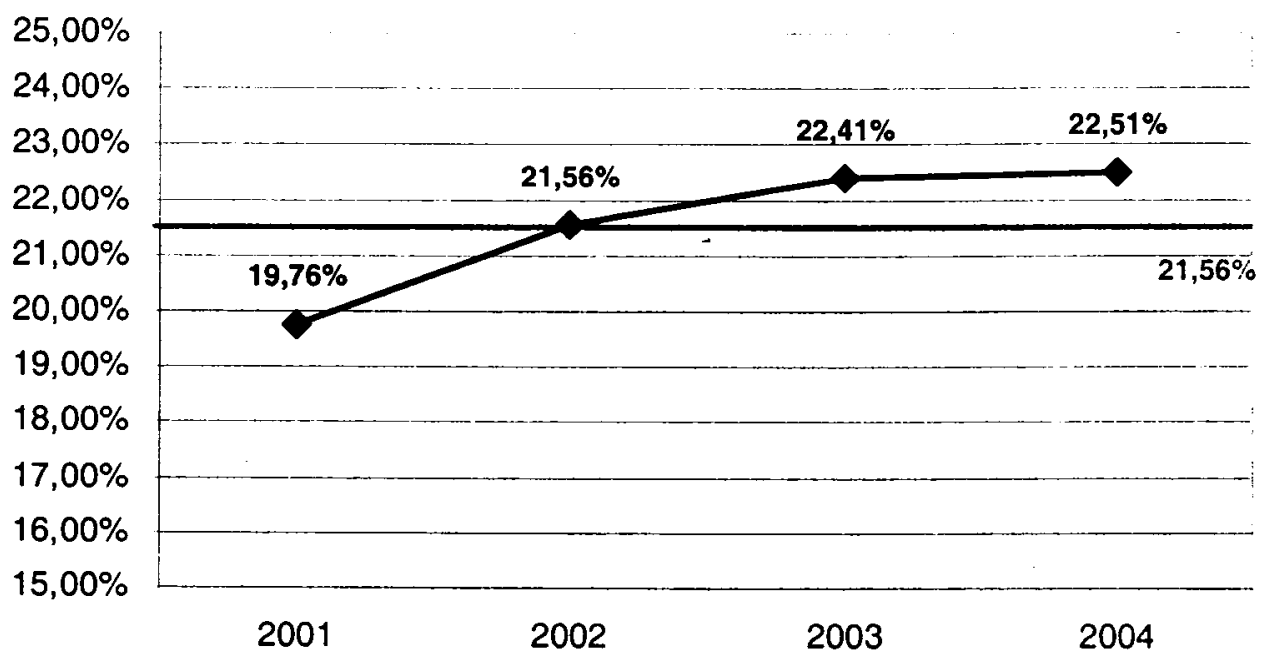




\section{Análise parcial:}

$O$ indicador retrata o conjunto de agravos, embargos de declaração e embargos infringentes, cíveis e criminais, em relação à quantidade total de decisões proferidas (acórdãos e monocráticas) pelo segundo grau. Observe-se que o total de decisões é superior ao total de processos julgados (conforme Quadros 42 e 52):

- 65.715 processos julgados em 2001, gerando 79.213 decisões (mais $21.5 \%$ );

- 78.958 processos julgados em 2002, gerando 98.068 decisões (mais 25,6\%);

-83.498 processos julgados em 2003, gerando 104.444 decisões (mais $25,3 \%$ );

- 86.842 processos julgados em 2004, gerando 107.447 decisões (mais $24,4 \%$ ).

Significa que em cada 100 processos julgados no segundo grau, em 24 são proferidas duas ou mais decisões, o que sugere outra inferência: há retrabalho (revisão do mesmo julgamento) em cerca de um quarto dos processos julgados, notório que são matidas as decisões originais na grande maioria dos agravos internos ou regimentais e dos embargos declaratórios.

No período entre 2001 e 2004 , a quantidade de recursos internos cresceu $54,56 \%$, enquanto que a quantidade de decisões cresceu $35,64 \%$. Tais evoluções acabam por manter a taxa de recorribilidade interna aproximadamente constante, com média de $21,56 \%$, a indicar que em cada 100 decisões, 22 desafiam recursos.

10.9 Indicador de recorribilidade ao Supremo Tribunal Federal (STF)

$O$ indicador " permite concluir que quanto menor o valor obtido, maior é o grau de definitividade das decisões da Justiça estadual. Distinguiram-se as seguintes situações:

- total de recursos remetidos;

- total de recursos extraordinários autuados;

- total de agravos autuados;

- total de autuados.

\begin{tabular}{|c|c|}
\hline Fórmula & $V_{\mathrm{STF}}=\boldsymbol{P}_{\mathrm{STF}} / \boldsymbol{P}_{\mathrm{RA} \mathrm{I}}$ \\
\hline \multicolumn{2}{|l|}{ Legenda: } \\
\hline \multicolumn{2}{|c|}{$\boldsymbol{P}_{\text {STF }}=$ processos que geraram recurso ao STF. } \\
\hline \multicolumn{2}{|c|}{$\boldsymbol{P}_{\boldsymbol{R d 2}}=$ processos julgados na 2' instáncia } \\
\hline
\end{tabular}

11 Os números pertinentes aos indicadores de recorribilidade estão com três casas decimais em face de assegurar, pelo menos, dois algarismos significativos, com o fím de evitar distorções significativas, decorrentes de aproximaçōes automáticas de aplicativos utilizados. 
Quadro 46 - Recorribilidade ao STF

\begin{tabular}{|l|r|r|r|r|}
\hline \multicolumn{1}{|c|}{ Taxa de Recorribilidade ao STF } & \multicolumn{1}{c|}{2001} & \multicolumn{1}{c|}{2002} & \multicolumn{1}{c|}{2003} & \multicolumn{1}{c|}{2004} \\
\hline STF (remetidos) & 0,025 & 0,025 & 0,033 & 0,064 \\
\hline STF (autuados - recursos) & 0,053 & 0,062 & 0,071 & 0,119 \\
\hline STF (autuados - agravos) & 0,024 & 0,029 & 0,043 & 0,077 \\
\hline STF (autuados - total) & 0,077 & 0,091 & 0,114 & 0,197 \\
\hline
\end{tabular}

\section{Quadro 46.1 - Evolução temporal do indicador}

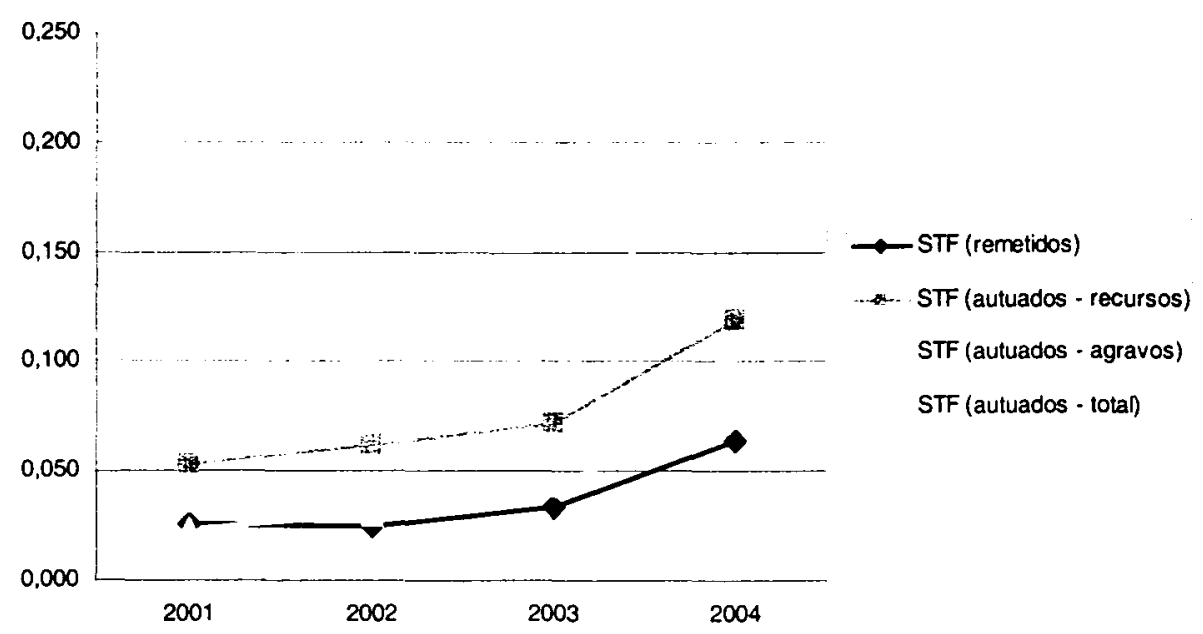

Análise parcial (ordem de apresentação de acordo com a legenda do gráfico, de cima para baixo):

O Indicador denota comportamento similar nas suas quatro formulações, apresentando tendência crescente, de natureza geométrica, entre 2001 e 2004. provável consequiência da crescente "constitucionalização" do direito brasileiro, no sentido de ser cada vez maior o número de temas e questões tratados na Constituição Federal, o que estimula as partes a recorrerem até o Supremo Tribunal Federal, que é a Corte guardiã da Constituição, quando suas teses constitucionais saem derrotadas nos tribunais estaduais.

$\mathrm{O}$ indicador retrata:

a) com relação ao total de recursos admitidos no PJERJ e remetidos ao STF:

- entre 2001 e 2002, estabilidade; de 2002 a 2003, aumento de 32,00\%; entre 2003 e 2004 , aumento de $93,94 \%$.

b) com relação ao total de recursos extraordinários autuados no PJERJ:

- entre 2001 e 2002 , aumento de $16,98 \%$; de 2002 a 2003, aumento de $14,52 \%$; entre 2003 e 2004 , aumento de $67,61 \%$; 
c) com relação ao total de agravos autuados no PJERJ:

- entre 2001 e 2002 , aumento de $16,98 \%$; de 2002 a 2003, aumento de $48,28 \%$; entre 2003 e 2004 , aumento de $79,07 \%$;

d) com relação ao total de autuados:

- entre 2001 e 2002 , aumento de $18,18 \%$; de 2002 a 2003, aumento de $25,27 \%$; entre 2003 e 2004 , aumento de $72,81 \%$.

10.10 Indicador de recorribilidade ao Superior Tribunal de Justiça $\left(V_{\mathrm{STJ}}\right)$

O indicador permite concluir que quanto menor o valor obtido, maior é o grau de definitividade das decisões da Justiça estadual. Distinguiram-se as seguintes situações:

- total de recursos remetidos;

- total de recursos ordinários autuados;

- total de agravos autuados;

- total de autuados.

\begin{tabular}{|c|c|}
\hline Fórmula & $V_{\text {STJ }}=P_{\text {STJ } /} P_{\text {Ad } 2}$ \\
\hline \multicolumn{2}{|l|}{ Legenda: } \\
\hline \multicolumn{2}{|c|}{$\boldsymbol{P}_{\mathrm{STJ}}=$ processos que geraram recurso ao STJ. } \\
\hline \multicolumn{2}{|c|}{$\boldsymbol{P}_{\boldsymbol{A d Z}}=$ processos julgados na $2^{\mathbf{4}}$ instância } \\
\hline
\end{tabular}

Quadro 47 - Recorribilidade ao STJ

\begin{tabular}{|l|r|r|r|r|}
\hline \multicolumn{1}{|c|}{ Taxa de Recorribilidade ao STJ } & \multicolumn{1}{c|}{2001} & \multicolumn{1}{c|}{2002} & \multicolumn{1}{c|}{2003} & \multicolumn{1}{c|}{2004} \\
\hline STJ (remetidos) & 0,070 & 0,093 & 0,125 & 0,134 \\
\hline STJ (autuados - recursos) & 0,139 & 0,173 & 0,171 & 0,178 \\
\hline STJ (autuados - agravos) & 0,056 & 0,088 & 0,099 & 0,113 \\
\hline STJ (autuados - total) & 0,195 & 0,261 & 0,271 & 0,256 \\
\hline
\end{tabular}




\section{Quadro 47.1 - Evolução temporal do indicador}

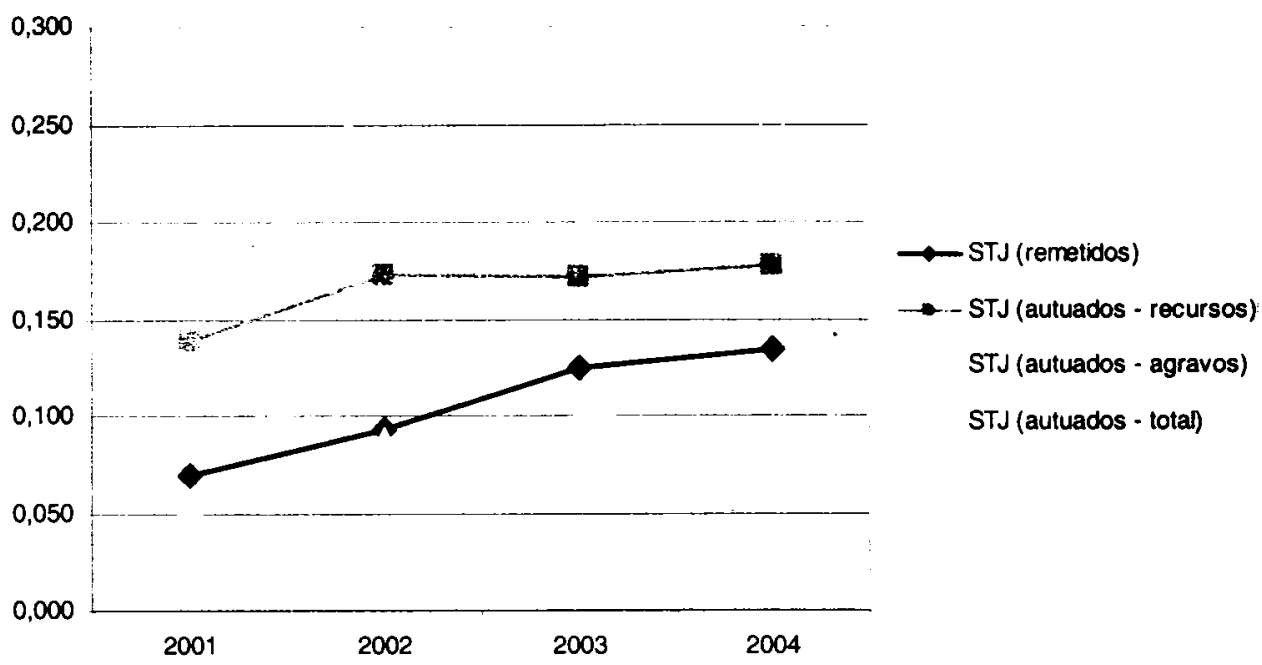

\section{Análise parcial:}

Diferentemente do anterior, este Indicador (recorribilidade ao STJ) denota, nas suas quatro formulações, aumento entre 2001 e 2003 e, em seguida, tendência à estabilidade, à exceção do total de agravos autuados no PJERJ, que mantém o dobro do ritmo de crescimento dos demais.

$\mathrm{O}$ indicador retrata:

a) com relação ao total de recursos admitidos no PJERJ e remetidos ao STJ:

- entre 2001 e 2002, aumento de $32,86 \%$; de 2002 a 2003, aumento de $34,41 \%$; entre 2003 e 2004, aumento de $7,20 \%$;

b) com relação ao total de recursos ordinários autuados no PJERJ:

- entre 2001 e 2002, redução de $24,46 \%$; entre 2002 a 2003, redução de $1,16 \%$; entre 2003 e 2004, aumento de $4,09 \%$;

c) com relação ao total de agravos autuados no PJERJ:

- entre 2001 e 2002 , aumento de $57,14 \%$; de 2002 a 2003, aumento de 12,50\%; entre 2003 e 2004, aumento de $14,14 \%$;

d) com relação ao total de autuados:

- entre 2001 e 2002, aumento de 33,85\%; de 2002 a 2003, aumento de 3,83\%; entre 2003 e 2004 , redução de 5,54\%. 
10.11 Indicador de reforma da decisão $\left(R_{\mathrm{d}}\right)$

\begin{tabular}{|l|l|}
\hline \multicolumn{1}{|c|}{ Fórmula } & $\boldsymbol{R}_{d}=R_{p} / R_{f}$ \\
\hline Legenda: & \\
$R_{p}=$ Recursos providos (ainda que parcialmente) \\
$R_{l}=$ Recursos julgados
\end{tabular}

Quadro 48 - Indicador de reforma da decisão

\begin{tabular}{|c|c|c|c|c|}
\hline \multirow{2}{*}{ Sentença/Decisão } & \multicolumn{4}{|c|}{ Quantidade/Ano } \\
\hline & 2001 & 2002 & 2003 & 2004 \\
\hline Confirmada & 25.705 & 26.416 & 26.396 & 27.284 \\
\hline Reformada & 8.279 & 8.270 & 8.618 & 7.647 \\
\hline Reformada parcialmente & 6.030 & 6.415 & 7.510 & 7.987 \\
\hline Anulaçāo & 489 & 523 & 472 & 396 \\
\hline Outros (desistência, acordo etc.) & 9.340 & 12.086 & 15.028 & 16.259 \\
\hline Total de Sentenças $\left(R_{i}\right)$ & 49.843 & 53.710 & 58.024 & 59.573 \\
\hline Total de Sentenças Reformadas $\left(R_{p}\right)$ & 14.309 & 14.685 & 16.128 & 15.634 \\
\hline Taxa de Reforma da Decisão & $28,71 \%$ & $27,34 \%$ & $27,80 \%$ & $26,24 \%$ \\
\hline
\end{tabular}

Quadro 48.1 - E.volução Temporal do Indicador

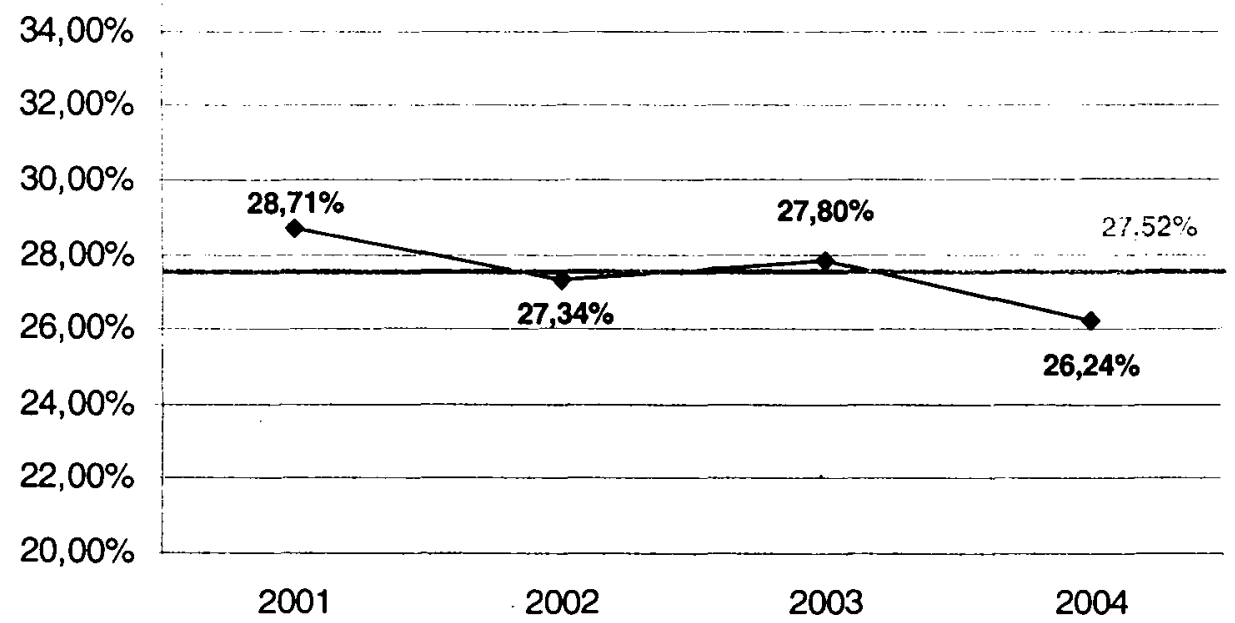




\section{Análise parcial:}

Observa-se discreto declínio do indicador, com tendência a estabilizar-se em torno de $27 \%$, o que mostra ser este o valor típico e constante para as reformas, totais ou parciais, pelo segundo grau da justiça estadual, das sentenças proferidas no primeiro grau.

10.12 Indicador de tempo médio para prolatação de sentenças e acórdãos

a) primeira instância (sentenças):

Quadro 49 - Tempo médio para prolatação de sentenças

\begin{tabular}{|c|r|}
\hline \multicolumn{2}{|c|}{ Tempo Médio de Sentenças (dias) } \\
\hline 2001 & 777,30 \\
\hline 2002 & 862,46 \\
\hline 2003 & 814,92 \\
\hline 2004 & 780,79 \\
\hline
\end{tabular}

Tempo Médio de Sentenças nos últimos 3 anos (dias)

\begin{tabular}{|l|r|}
\hline 2001 & 354,94 \\
\hline 2002 & 354,43 \\
\hline 2003 & 353,16 \\
\hline 2004 & 388,33 \\
\hline
\end{tabular}

Quadro 49.1 - Evolução temporal do indicador

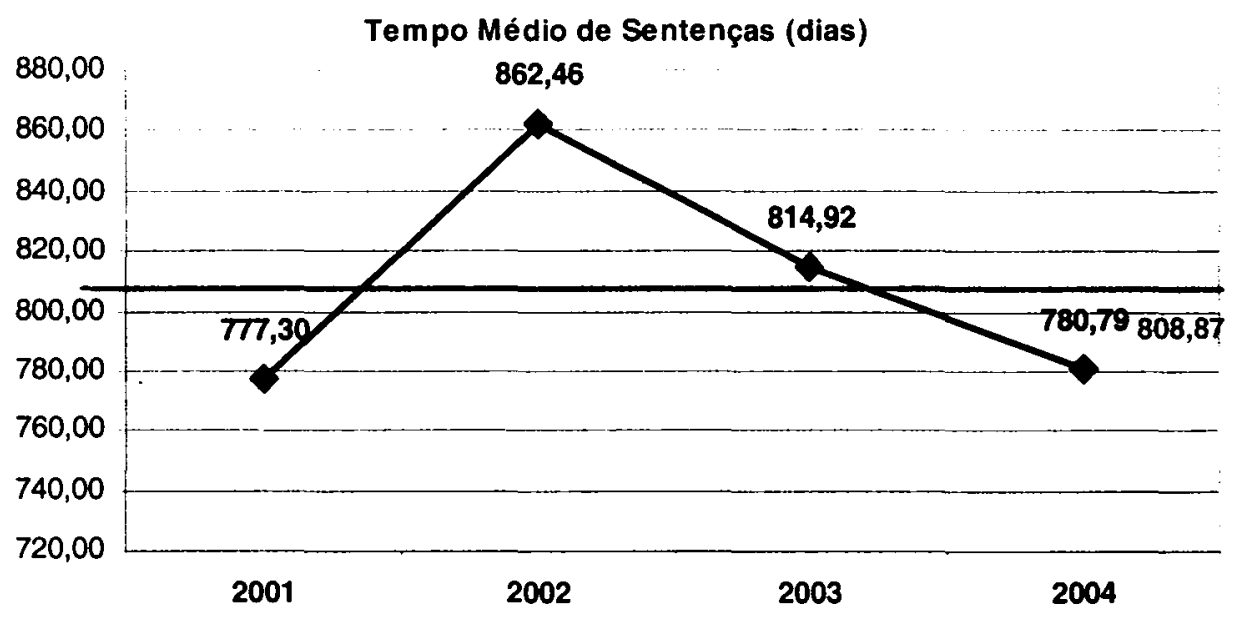




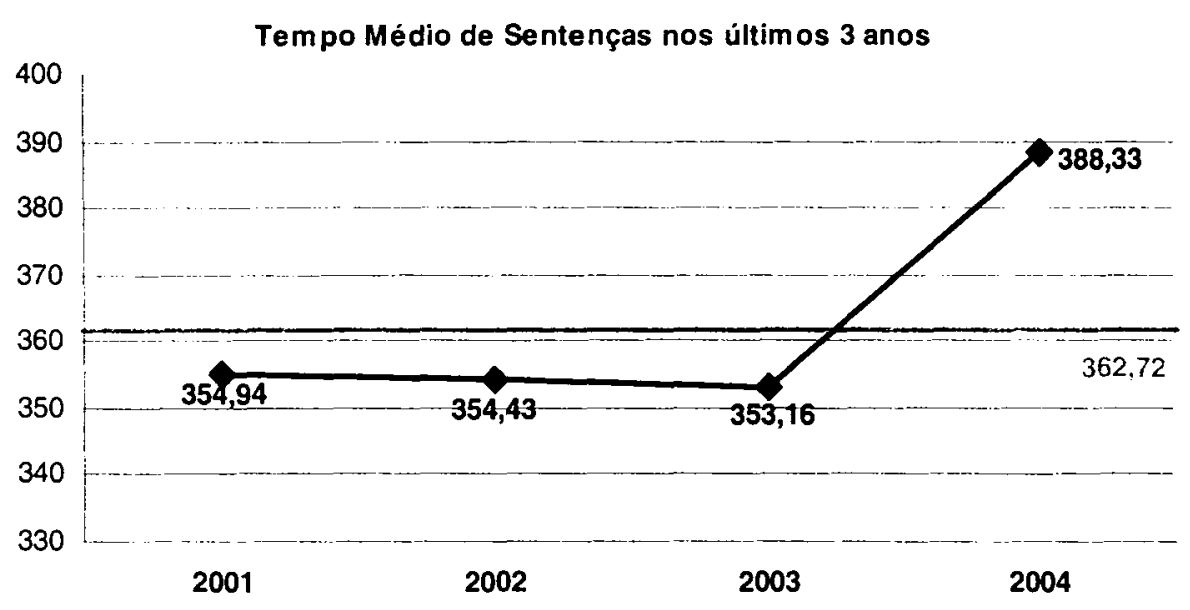

\section{Análise parcial:}

São apresentados dois indicadores para analisar o tempo médio para a prolatação de sentenças. O primeiro indicador considera todo o acervo do cartório, no qual podem ser encontrados processos judiciais que remontam à data de criação do Juízo (Vara), combinados com processos cuja fase de execução tramita há vários anos. Como consequiência, observam-se oscilações importantes em torno da média $(808,87$ dias), provavelmente decorrentes da influência de processos antigos.

O segundo indicador retrata a produção do Juízo nos últimos três anos, desprezando processos judiciais com história inferior a três anos. Como consequiência, observa-se redução de $223 \%$ no tempo médio para a prolatação de sentença, regularidade expressa pela média de 362,72 dias e desvio padrão de 17,09, provavelmente decorrente de processos antigos.

\section{Quadro 50 - Tempo médio para prolatação de acórdãos}

\begin{tabular}{|l|c|c|c|c|}
\hline \multicolumn{1}{|c|}{ 2: Instância $^{\mathbf{2}}$} & $\mathbf{2 0 0 1}$ & $\mathbf{2 0 0 2}$ & $\mathbf{2 0 0 3}$ & $\mathbf{2 0 0 4}$ \\
\hline $\begin{array}{l}\text { Tempo Médio Autuação x Julgamento (Câmaras } \\
\text { Civeis e Criminais), medido em dias }\end{array}$ & 168 & 158 & 142 & 142 \\
\hline $\begin{array}{l}\text { Tempo Médio Autuação x Distribuição - Câmaras } \\
\text { Cíveis, medido em dias }\end{array}$ & 34 & 6 & 8 & 10 \\
\hline $\begin{array}{l}\text { Tempo Médio Autuação x Distribuição - Cámaras } \\
\text { Criminais, medido em dias }\end{array}$ & 16 & 6 & 11 & 8 \\
\hline
\end{tabular}




\section{Quadro 50.1 - Evolução temporal do indicador}

Tempo Médio Autuação x Julgamento (Câmaras Civeis e Criminais)

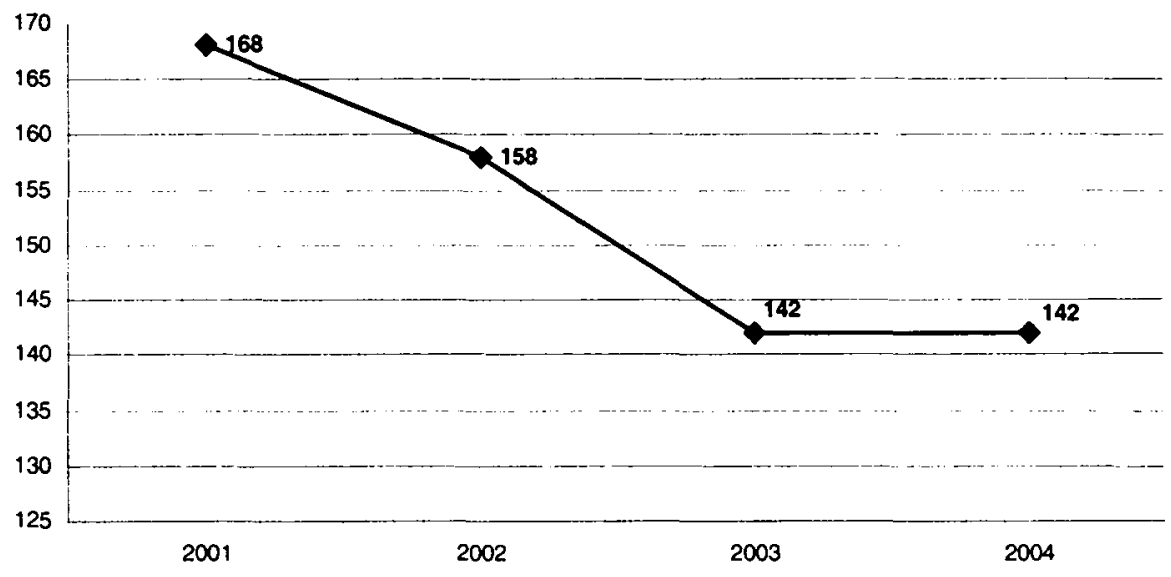

Tempo Médio Autuação x Distribuição ao Relator - Câmaras Cíveis
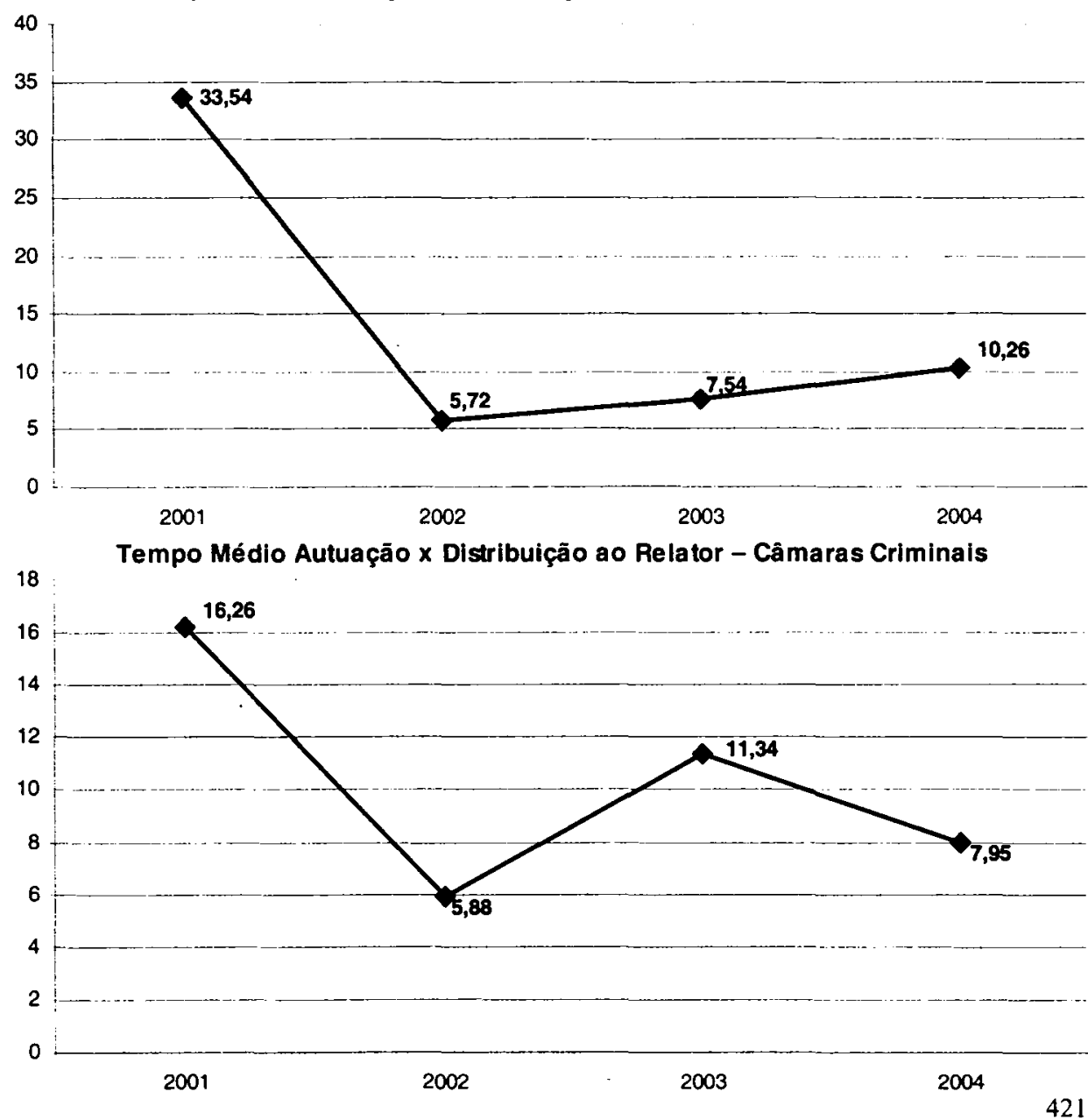


\section{Análise parcial:}

- quanto ao tempo entre a autuação do processo (recurso) e o respectivo julgamento, observa-se redução total de $15.48 \%$ entre 2001 e 2004. indicando tendência à estabilização em 142 dias, o que sinaliza ser este o tempo razoável típico do respectivo processo de trabalho;

- quanto ao tempo entre a autuação do processo (recurso) e a distribuição ao respectivo relator nas câmaras cíveis, observa-se redução de $82,35 \%$ entre 2001 e 2002 , seguida de pequeno e continuado crescimento da ordem de $35 \%$ ao ano, rumo ao tempo médio de dez dias;

- quanto ao tempo entre a autuação do processo (recurso) e a distribuição ao respectivo relator nas câmaras criminais, observa-se oscilação do indicador, com forte redução entre 2001 e 2002, seguida de flutuação, para mais e para menos, com média em torno de oito dias.

No tempo decorrido entre a autuação do processo (recurso ou ação de competência originária da Câmara) e a sua distribuição ao respectivo desembargador-relator realizam-se tarefas administrativas de controle (anotações e registros). Pode ser ainda mais reduzido e deve, para fins de aferição de produtividade, ser abatido do tempo que medeia entre a autuação do processo e o seu julgamento. Conclui-se que, no segundo grau do PJERJ, o tempo médio de julgamento de um processo é de quatro meses e meio, havendo Câmaras que vêm reduzindo esse tempo à metade ( 72 dias).

10.13 Indicador de quantidade de sentenças e acórdãos

a) primeira instância (sentenças):

$$
\text { Quadro } 51 \text { - Quantidade de sentenças (primeira instância) }
$$

\begin{tabular}{|c|c|c|c|c|}
\hline \multirow{2}{*}{ Julgados } & 2001 & 2002 & 2003 & 2004 \\
\hline & Total & Total & Total & Total \\
\hline $1^{\text {a }}$ Instância & 314.438 & 347.798 & 362.581 & 343.758 \\
\hline Juizados Especiais & 229.307 & 306.811 & 354.523 & 388.277 \\
\hline Total & 543.745 & 654.609 & 717.104 & 732.035 \\
\hline
\end{tabular}


Quadro 51.1 - Evolução temporal do indicador

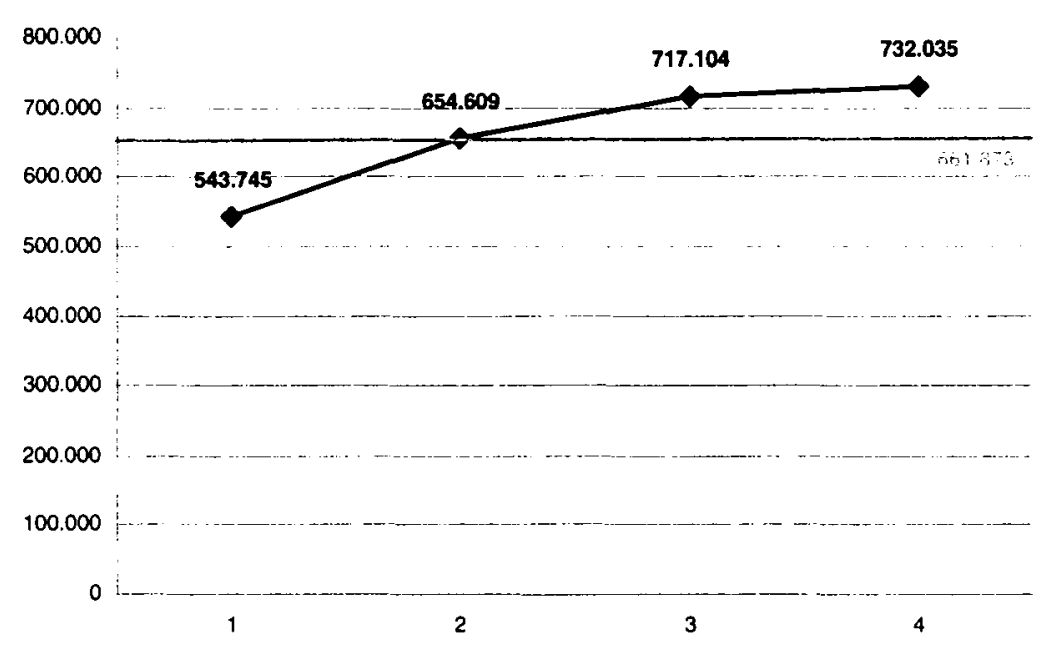

\section{Análise parcial:}

O indicador retrata crescimento de $20,34 \%$ no período de 2001 a 2002 ; crescimento de $9,55 \%$ entre 2002 e 2003 , e aumento de $2,08 \%$ entre 2003 e 2004, resultado que requer análise mais aprofundada, por se constituir em paradoxo, dados o aumento do número de juízes e o crescimento do volume de ações judiciais, ocorridos no quadriênio.

b) segunda instância (acórdãos):

Quadro 52 - Quantidade de acórdãos e decisões monocráticas (segunda instância)

\begin{tabular}{|c|c|c|c|}
\hline \multirow{2}{*}{ Ano } & \multicolumn{3}{|c|}{ Votos Proferidos } \\
\cline { 2 - 4 } & Acórdãos & Decisões & Total \\
\hline 2001 & 66.275 & 12.938 & 79.213 \\
\hline 2002 & 77.064 & 21.004 & 98.068 \\
\hline 2003 & 81.205 & 23.239 & 104.444 \\
\hline 2004 & 84.465 & 22.982 & 107.447 \\
\hline
\end{tabular}


Quadro 52.1 - Quantidade de processos julgados (segunda instância)

\begin{tabular}{|c|c|}
\hline Ano & Processos Julgados \\
\hline 2001 & 65.715 \\
\hline 2002 & 78.958 \\
\hline 2003 & 83.498 \\
\hline 2004 & 86.842 \\
\hline
\end{tabular}

\section{Quadro 52.1.1 - Evolução temporal do indicador}

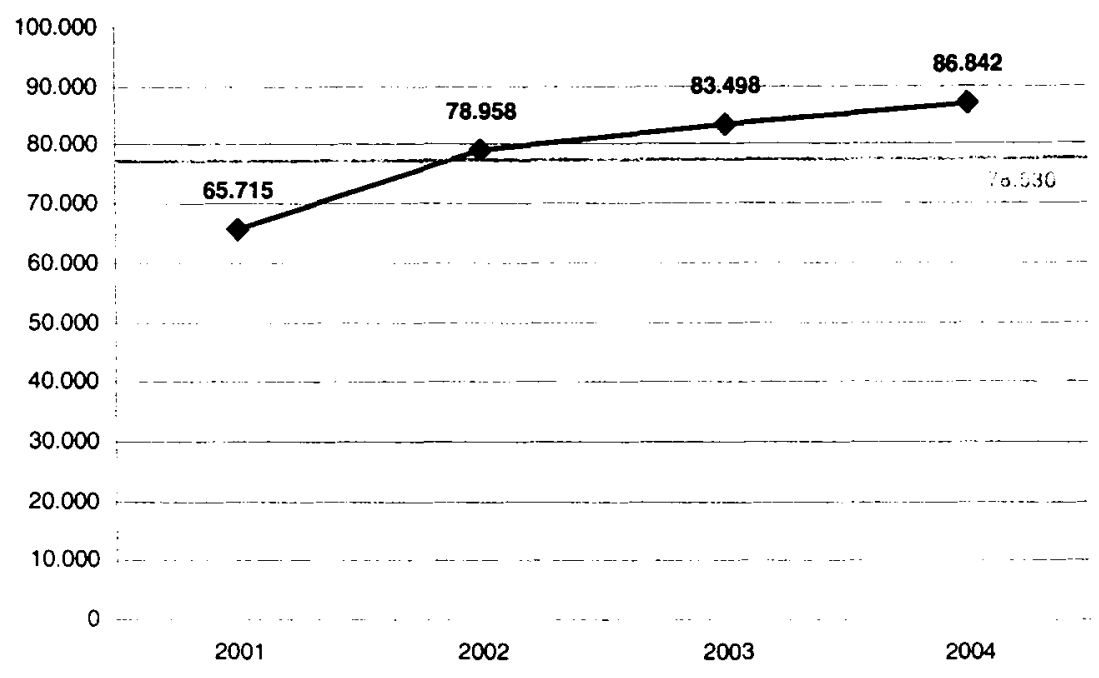

\section{Análise parcial:}

- A quantidade de processos julgados revela crescimento contínuo médio anual de $9,97 \%$, representando carga de trabalho média de 490,81 processos por desembargador-ano, no quadriênio.

- Em 2004, a carga de trabalho foi de 724 processos por desembargador-ano. Comparada à carga de trabalho média de juízes, 9.005 processos por juiz-ano, em 2004 (incluindo todo o acervo, isto é, cartas precatórias, notificações, protestos, interpelações, justificações e executivos fiscais), indica que a relação entre a carga de trabalho de juízes e a de desembargadores seria de seis vezes.

Tal comparação se faz entre atividades heterogêneas quanto aos respectivos processos de trabalho, embora homogêneas quanto à sua natureza judicante. A utilidade da comparação reside em evidenciar a ordem de grandeza material dessa diversidade, não para extremar o empenho intelectual exigente de cada qual, que é o mesmo, pautado pelos princípios e normas regentes da ordem jurídica. 
Consoante se assinalou no item 10.4 (indicador da carga de trabalho), cabe ao juiz conceber a solução do conflito que as partes lhe apresentam em cada demanda, inclusive colhendo as provas que sejam necessárias; o desembargador limita-se, salvo situações inusitadas ou casos de singular complexidade, a avaliar, mediante a provocação dos recursos interpostos pelas partes insatisfeitas, se a solução concebida pelo juiz foi a adequada, raramente tendo de refazer provas. Sob a perspectiva estrita do volume é que se torna possível estimar em seis vezes a carga de trabalho do juiz em face da carga de trabalho do desembargador.

Para ilustrar faticamente a diferença física dos processos de trabalho de cada qual, recorde-se que um juiz de Vara Cível da Comarca da Capital necessita de realizar, diariamente, várias audiências de instrução (para colher depoimentos de partes e testemunhas), além de ter de impulsionar dezenas de processos e decidir variados incidentes interlocutórios, ao passo que um desembargador de Câmara Cível participa de uma sessão de julgamento colegiado por semana (pauta média de 70 processos, distribuídos entre cinco relatores), dedicando os demais dias ao estudo dos recursos que sejam distribuídos à sua relatoria (média de 20 por semana).

Tal diversidade deixa claro por que a média de julgamentos/ano de um desembargador (o acórdão revê a sentença recorrida) tende a ser maior do que a média de julgamentos/ano de um juiz (a sentença culmina a dilação probatória e o contraditório, formulando a solução do conflito), apesar do acervo deste ser maior do que $o$. daquele. E justifica a decisão estratégica do PJERJ, para o biênio de 2005-2006, de edificar prédio menor (três pavimentos) para acolher as Câmaras (lâmina III do Palácio da Justiça) e alargar os espaços das lâminas I e II (até 12 pavimentos) para a melhor acomodação de Varas, Juizados e unidades administrativas, no Foro Central da Comarca da Capital. A par de vir, desde os Planos Bienais de Ação Governamental iniciados em 1999, reformando e construindo foros regionais e de Comarcas, em esforço, que deve permanecer, para melhor aparelhar o dia-a-dia dos trabalhos da primeira instância.

\section{INDICADORES RELACIONADOS AO ACESSO À JUSTIÇA}

\subsection{Indicador de despesa com assistência judiciária sobre o PIB Estadual $\left(A_{1}\right)$}

\begin{tabular}{|l|l|}
\hline \multicolumn{1}{|c|}{ Fórmula } & $A_{1}=J G /(P I B / R J)$ \\
\hline Legenda: \\
JG = Assisténcia Judiciária Gratuita no Estado \\
PIB/RJ = Produto Intemo Bruto do Estado do Rio de Janeiro \\
\hline
\end{tabular}


Quadro 53 - Indicador de despesa com assistência judiciária gratuita sobre a riqueza do Estado (PIB/RJ)

\begin{tabular}{|l|r|}
\hline \multicolumn{1}{|c|}{$\begin{array}{c}\text { Assistência Judiciária sobre o } \\
\text { PIB/RJ }\end{array}$} & \multicolumn{1}{|c|}{ Valor } \\
\hline $\begin{array}{l}\text { Assistência Judiciária Gratuita no } \\
\text { Estado (JG) }\end{array}$ & $74.415 .000,00$ \\
\hline $\begin{array}{l}\text { Produto Interno Bruto do Estado do Rio } \\
\text { de Janeiro (PIB) }\end{array}$ & $\mathbf{2 3 6 . 6 0 7 . 6 2 4 . 0 0 0 , 0 0}$ \\
\hline$\left(\mathbf{A}_{1}\right)$ & $\mathbf{0 , 0 3 \%}$ \\
\hline
\end{tabular}

\section{Análise parcial:}

Nos termos em que foi proposto pelo STF, o indicador poderá ter significação se comparado com valores de outras instituições do Judiciário ou ao longo do tempo para uma mesma instituição. Este RIGER dispôs do dado de um ano apenas, o que ainda não permite confronto revelador de tendências.

\section{II.2 Indicador de despesa com assistência judiciária sobre a despesa pública} total $\left(A_{2}\right)$

\begin{tabular}{|l|l|}
\hline \multicolumn{1}{|c|}{ Fórmula } & $A_{2}=J G / D T$ \\
\hline Legenda: \\
JG = Assistência Judiciária Gratuita no Estado \\
DT = Orçamento total do Estado do Rio de Janeiro
\end{tabular}

Quadro 54 - Indicador de despesa com assistência judiciária sobre a despesa pública total

\begin{tabular}{|c|c|}
\hline $\begin{array}{c}\text { Assistência Judiciária sobre a } \\
\text { despesa pública total }\end{array}$ & Valor \\
\hline $\begin{array}{l}\text { Assistência Judiciária Gratuita no } \\
\text { Estado (JG) }\end{array}$ & $74.415 .000,00$ \\
\hline $\begin{array}{l}\text { Orçamento total do Estado do Rio de } \\
\text { Janeiro (DT) }\end{array}$ & $32.690 .423 .000,00$ \\
\hline$\left(A_{2}\right)$ & $0,23 \%$ \\
\hline
\end{tabular}




\section{Análise parcial:}

Reitera-se a observação lançada no item 11.1, com a ressalva de que, no item 11.2, a análise pode ser enriquecida quando se compara o valor da assistência judiciária gratuita com o orçamento destinado a bens e serviços em 2004, levando-se em conta que as correspondentes despesas ( $\mathrm{R} \$ 332.205 .000,00)$ são providas pelos recursos do Fundo Especial do Tribunal de Justiça (FETJ). Vale dizer que o gasto com a assistência judiciária gratuita consome $22 \%$ das receitas do FETJ, parcela que se torna indisponivel para custeio e investimento do PJERJ, embora cumpra com uma das mais relevantes funções de um fundo público estatal, que é a de "promover o equilíbrio sócio-econômico" ( $\mathrm{CF} / 88^{13}$, art. 161, II).

A importância do indicador está nessa medida: o aumento da taxa de comprometimento das receitas do FETJ com o custeio dos processos beneficiados pela gratuidade da justiça significa redução da capacidade de investimento em melhorias do sistema judiciário; acima de determinado nível, o aumento passa a inviabilizar a autonomia do sistema, que voltaria a depender de repasses do Tesouro estadual, como ocorria anteriormente à criação e à expansão do FETJ (1996-1999); e, por óbvio, o decrescimento do indicador liberaria recursos do FETJ para novos investimentos.

Tomando-se por base os dados da realização orçamentária de 2004, o nível crítico, a partir do qual o PJERJ veria sacrificada a sua autonomia financeira para investimentos, seria atingido se o custeio da gratuidade de justiça absorvesse $64 \%$ das receitas do FETJ. Este dado considera, para o biênio 2005-2006, a ingresso da receita de $\mathrm{R} \$ 204.285 .962,00$, proveniente de convênios que reforçam em $74 \%$ os recursos do FETJ, mas que podem não ser renovados, tornando ainda mais crítica a influência da gratuidade de justiça sobre o funcinamento do PJERJ.

\subsection{Indicador de despesa com assistência judiciária gratuita por habitante $\left(A_{3}\right)$}

\begin{tabular}{|l|l|}
\hline \multicolumn{1}{|c|}{ Fórmula } & \multicolumn{1}{|c|}{$A_{3}=J G / h_{1}$} \\
\hline Legenda: \\
$J G=$ Assisténcia Judiciária Gratuita no Estado \\
$h_{1}=$ nümero de habitantes no Estado
\end{tabular}

13 Art. 161,II - estabelecer normas sobre a entrega dos recursos de que trata o Art. 159, especialmente sobre os critérios de rateio dos fundos previstos em seu inciso I, objetivando promover o equilíbrio sócio-econômico entre Estados e entre Municípios. 


\section{Quadro 56.1 - Evolução Temporal do Indicador}

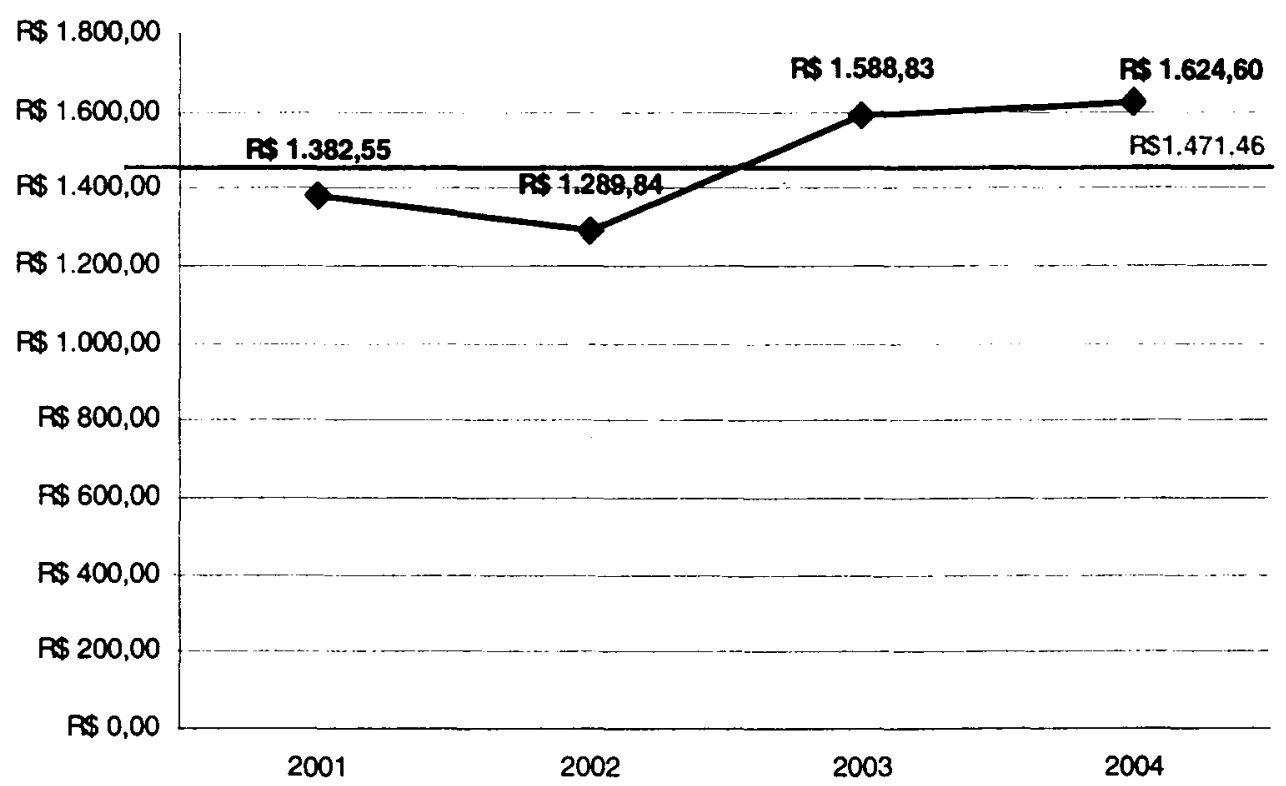

\section{Análise parcial:}

O custo unitário de processos julgados, média de $\mathrm{R} \$ 1.471,46$, diminuiu $6,71 \%$ entre 2001 e 2002 , aumentou $23,18 \%$ entre 2002 e 2003, tendendo a estabilizar-se em 2004 (R\$ 1.624,60). A redução entre 2001 e 2002 pode ser explicada por inconsistências geradas durante a automatização de coleta das informações no PJERJ, ocorrida naquele período.

Em face da tendência à estabilização, o valor médio entre 2003 e 2004 (R\$ $1.606,72)$ parece estar mais próximo da realidade do custo unitário. Equivale a cerca seis vezes o valor do salário mínimo vigente. Embora possa parecer elevado quando observado isoladamente, merece ser analisado em conjunto com os indicadores de congestionamento, comparado à média nacional (dado ainda não disponível) e com outras realidades, de modo a estabelecer a sua eficiência.

\subsection{Indicador do número de pessoas atendidas}

Não há dados disponíveis para calcular o indicador, tendo em vista a limitação do Sistema DCP, que controla o número de processos, mas não o número de partes em cada processo. Os respectivos totais não coincidem por ser corriqueira a formação de litisconsórcios ativos (vários autores da mesma ação) e passivos (vários réus da mesma ação). Ademais, é também possível que a mesma pessoa seja autora ou ré em mais de uma ação, o que geraria superposições na contagem do número de pessoas atendidas pelo PJERJ. Estão sendo planejadas ações de melhoria no cadastro de litigantes, no sentido de permitir a geração de informações sobre o número de pessoas 
atendidas, a exemplo da obrigatoriedade de identificação individual única (por CPF) de autores, réus e advogados.

A falta dos dado específico não impede a configuração de perfil aproximado do indicador, mediante a extrapolação razoável de outros dados disponíveis.

Assim: o número médio de componentes da unidade familiar brasileira é de cinco pessoas, do que se extrai que a população global fluminense ( 15 milhões de habitantes) comporta três milhões de famílias; em 2004, ingressaram no PJERJ cerca de um milhão de novas ações; são protagonistas de uma ação ao menos duas partes (autor e réu), o que corresponde a dois milhões de pessoas, ou seja, 400 mil unidades familiares; segue-se que $13 \%$ das famílias residentes no território fluminense participariam, diretamente, a cada ano, de demandas judiciais. Desse percentual haveria de descontar-se o número de demandas ajuizadas ou respondidas por pessoas jurídicas, dado que não se dispõe.

\subsection{Indicador do grau de satisfação do usuário}

\section{Quadro 57 - Indicador de satisfação do usuário}

\begin{tabular}{|l|c|}
\hline \multicolumn{1}{|c|}{ Unidade Organizacional } & Grau de Satisfação Geral (\%) \\
\hline EMERJ & 81 \\
\hline $18^{\text {a }}$ Câmara Cível & 76 \\
\hline $13^{\text {a }}$ Vara Civel da Comarca da Capital & 94 \\
\hline
\end{tabular}

\section{Análise parcial:}

Atendendo às respectivas peculiaridades das unidades pesquisadas, as metodo- logias e os instrumentos de pesquisa adotados não foram os mesmos, por isto que os resultados devem ser relativizados. Ademais, a medição da satisfação de usuários iniciou-se, de forma sistemática, com a Certificação NBR ISO 9001:2000, obtida em 2004, para três unidades, constituindo prática recente, a ser doravante aperfeiçoada e tornada corriqueira para todos os 1.319 órgãos prestadores de jurisdição e unidades administrativas do PJERJ.

Os primeiros passos permitem afiançar que a satisfação dos usuários pode ser considerada boa naquelas três unidades ( $81 \%$ na EMERJ, $76 \%$ na $18^{\mathrm{a}}$ Câmara Cível e $94 \%$ na $13^{\mathrm{a}}$ Vara Cível), conquanto isoladamente pouco representem no universo do PJERJ. O excelente desempenho da $13^{\mathrm{a}}$ Vara Cível da Comarca da Capital, cuja medida da satisfação dos usuários é comparável a organizações de ponta da iniciativa privada, o que é inusitado no serviço público, serve de alento e paradigma. Ali, a pesquisa computou a opinião de 200 usuários (frequientam a Vara cerca de 1.200 usuários/mês), avaliando-lhes a percepção em relação à eficácia do atendimento, ao tempo dispendido no atendimento, à clareza das informações, à cortesia do atendente e à localização do processo no ato da procura. 
Não há dados disponíveis para calcular o indicador, tendo em vista a limitação do Sistema DCP. Estão sendo planejadas ações de melhoria no cadastro de litigantes, no sentido de permitir a geração de informações sobre o perfil de demanda (ações propostas por ou contra), a exemplo da adoção de tipologia para a identificação única de autores, réus e advogados, discriminando, entre outros:

- governos federal, estadual e municipal;

- fundos de previdência federais, estaduais e municipais;

- bancos federais e estaduais.

\section{CONCLUSÕES}

\subsection{Gerais}

A elaboração deste RIGER PJERJ-1/2005 contou com a colaboração de profissionais de variada formação, mas que têm em comum o fato de militarem no interior do sistema judicial. De um lado, essa especialização assegura compromisso com a pertinência e a realidade, afastando "achismos" e conjecturas com que costumam discursar os que julgam pelas aparências, por ouvir dizer ou para produzir textos acadêmicos ou promocionais. Por outro lado, a especialização conhece limites que somente a visão interdisciplinar superará, na medida em que analisa dados e indicadores que retratam fenômenos portadores de toda a riqueza dos conflitos humanos, que é a matéria-prima da prestação jurisdicional.

A primeira conclusão genérica que se extrai, portanto, é a de que este RIGER PJERJ-1/2005 dá apenas o primeiro passo consistente para que se decifrem os enigmas e se descubram as entranhas que há nas estatísticas judiciais. cujos armazéns devem ser ampliados e aperfeiçoados. De certo que economistas, sociólogos, historiadores, antropólogos, demógrafos, pedagogos, políticos e também juristas, entre outros, terão muito a indagar e a revelar sob suas próprias perspectivas, quer isolada ou integradamente. É por isto que este RIGER PJERJ-1/2005, e outros que o sucederão, devem ser disponibilizados para exame profissional e colocados a serviço da melhor compreensão que a sociedade precisa ter sobre os problemas de suas instituições.

A segunda conclusão genérica visa a resultados mais próximos. É mais do que chegada a hora de o Poder Judiciário brasileiro se estruturar e se comportar como um sistema de abrangência nacional. Já o é nos termos da Constituição da República. que define os perfis nacionais dos tribunais e da magistratura $(C F / 88$, artigos 92 a 100) e lhes dá como principal instrumento de pacificação dos conflitos um conjunto de princípios e normas que igualmente almeja validade e alcance nacionais (CF/88, art. 22, I). Falta uma política de gestão nacional, gerida por indicadores objetivos e fiéis à realidade social, econômica e cultural do País e de cada uma de suas regiões. Este RIGER PJERJ-1/2005 pode vir a ser o embrião desses indicadores, sugerindo métodos, objetivos e metas que elevem o sistema judicial aos padrões de eficiência e de eficácia legitimamente desejados pelos jurisdicionados. E augura-se que o 
Conselho Nacional da Justiça, criado pela Emenda Constitucional n ${ }^{\circ} 45 / 2004$, venha a ser a sede adequada para a formulação dessa política nacional de gestão do Poder Judiciário, e, não, um cartório de queixas e reclamações.

O PJERJ está construindo a sua Árvore de Indicadores de Desempenho, que incluirá os indicadores estratégicos de todas os órgãos prestadores de jurisdição e unidades administrativas, além de considerar os indicadores estabelecidos pelo STF. E prepara-se para cumprir a meta de editar, no biênio 2005-2006, oito RIGER específicos sobre o perfil da prestação jurisidicional que os seus órgãos julgadores entregam, por matéria: Cível, Criminal, Empresarial, Fazenda Pública, Família, Infância e Adolescência, Órfãos e Sucessões, e Registros Públicos.

\subsection{Especificas} PJERJ:

Dos indicadores até aqui apurados é possível extrair-se o seguinte perfil do

\subsection{1 como estrutura organizacional (função administrativa):}

- 553 unidades administrativas dão suporte às atividades de 766 órgãos prestadores de jurisdição, formando conjunto que ocupa $410.727,46 \mathrm{~m}^{2}$ de área (10 processos por $\mathrm{m}^{2}$ e $26 \mathrm{~m}^{2}$ para cada servidor) nas 83 comarcas instaladas em que se divide a organização judiciária do Estado do Rio de Janeiro;

- o funcionamento desse sistema acarreta despesas que correspondem a $0,56 \%$ do PIB estadual e representam 4,25\% das despesas globais do Estado; a operação do sistema custa $\mathrm{R} \$ 87,50$ por habitante do território fluminense (população de 15,2 milhões, em 2004);

- do orçamento anual de R\$1,3 bilhões (2004), o PJERJ tem sido, desde 1999. auto suficiente quanto às despesas de custeio e investimento $(25 \%)$, cobertas pelas receitas do Fundo Especial do Tribunal de Justiça, e dependente do Tesouro do Estado para atender às despesas com pessoal $(75 \%)$;

- a capacitação de magistrados (5.641 partipações em 2004), iniciada em agosto de 2002, apresenta crescimento contínuo na quantidade de participantes, envolvendo mais de dez diferentes temas, dos quais direito penal (18\%) e direito civil (17\%) são os mais freqüentes;

- entre julho de 2000 e dezembro de 2004, participaram de Cursos de Iniciação e Vitaliciamento, em oito turmas e 41 eventos, 231 juízes vitaliciandos;

- a capacitação de sevidores apresenta crescimento em todos os indicadores: em 2004, foram 40.212 partipações, 19 horas/aula (carga horária média por participante) e 1.907 turmas, tendo sido abordados temas nas áreas comportamental, gerencial, técnica, jurídica, informática e conciliação;

- o sistema faz uso acentuado de tecnologias de informação: foi de 0,92 a relação computadores/usuário (magistrados e servidores) em 2004, mercê de investimentos que correspondem a 3,55\% das despesas globais anuais do PJERJ (2004), mas carece, ainda, de maior grau de automação em seus processos de trabalho;

- enquanto a população do Estado cresceu 4,43\% entre 2001 e 2004 , as despesas do PJERJ creceram $57,88 \%$, discrepância sugestiva de acumulada defasagem entre o número de demandantes e a capacidade instalada do sistema para atendê-los; 
- os indicadores relativos a despesas com bens e serviços, seja sobre o PIB estadual $(0,13 \%)$ ou sobre as demais despesas do próprio PJERJ (média de $23,43 \%$, entre 2001 e 2004), mostram tendência ascendente, a significar o esforço de expansão dos órgãos de prestação jurisdicional no período observado, porém sinalizam a necessidade de medidas que incrementem a receita e melhor controlem as despesas; o custo do processamento das ações beneficiadas com a gratuidade de justiça consome 22\% dos receitas do Fundo Especial do Tribunal de Justiça, subtraindo-as de atender às demais despesas de custeio e investimento;

- o indicador relativo a custo unitário de processo julgado apresenta média de $\mathrm{R} \$ 1.471,46$, entre 2001 e 2004, alcançando R\$1.624,60 em 2004; considerando a taxa de recorribilidade interna $(22,51 \%$, em 2004$)$, o custo médio de solução do processo judicial estaria em torno de $\mathrm{R} \$ 1.990,30$, na hipótese de ser julgado também na segunda instância.

\subsection{2 como instituição intermediadora de conflitos (função jurisdicional):}

- a jurisdição é prestada por 804 magistrados togados (sendo 160 desembargadores), 359 juízes de paz e 3.530 conciliadores (Juizados Especiais); a relação de magistrados por 100 mil habitantes cresceu $9,23 \%$ entre 2001 e 2004 , fixando-se, hoje, em 4,25 (juiz de direito) e 1,04 (desembargador); a relação de servidores por 100 mil habitantes também cresceu no período, passando de 83,93 (2001) para 101,19 (2004); em outras palavras, o sistema oferece, para cada 100 mil habitantes, 100 servidores, 4 juízes de direito e 1 desembargador, que produziram, entre 2001 e 2004, 3.039.117 julgamentos em 3.214.936 ações e 391.618 recursos, sendo 2.647 .493 em primeiro grau e 391.624 em segundo;

- o acervo de processos judiciais em tramitação (5.817.250, até 2004, excluídos 2.018 .089 procedimentos relativos a cartas precatórias, notificações, protestos, interpelações, justificações judiciais e executivos fiscais, que não demandam a prolatação de sentença) registrou, no período observado, quanto a ações novas, crescimento médio anual de $34,74 \%$ na primeira instância (os processos criminais constituem $13,87 \%$ do total dos processos cíveis), de $11 \%$ na segunda instância e de $48 \%$ nos Juizados Especiais; o afluxo pressiona sobretudo o primeiro grau de jurisdição cível, como evidenciam os indicadores de casos novos por juiz-ano nos Juizados Especiais (1.194 na jurisdição cível e 315 na jurisdição criminal), com maior concentração nos foros da Comarca da Capital (40\% da população do Estado e $36 \%$ do volume total de processos em curso no PJERJ);

- os indicadores que correlacionam o volume de processos à população estadual mostram que, a cada 16 habitantes, um gera um processo judicial cível, e que, a cada 162 habitantes, um gera um processo judicial criminal (desvio padrão de 7, nos processos cíveis, e de 27 , nos processos criminais, quando se comparam os indicadores dos onze núcleos geográficos em que se agrupam as regiões do Estado); a tendência se reitera na correlação de processos/habitantes perante os Juizados Especiais - a cada 50 pessoas, uma gera um processo cível (desvio padrão 18, entre os núcleos regionais), e a cada 76 pessoas, uma gera um processo criminal (desvio padrão também 18); sabendo-se que o desvio padrão é medida de dispersão dos 
valores de uma população ou amostra em relação à sua média, os desvios retro mencionados denotam elevado grau de heterogeneidade cultural na conduta/percepção das populações regionais quanto à iniciativa de provocar-se a intervenção da tutela jurisdicional estatal para a pacificação de conflitos;

- os indicadores de carga de trabalho de magistrados mostram que o número de processos/ano por juiz aumentou 34,74\% entre 2001 e 2004 (de 6.683 para 9.005), enquanto que, por desembargador. cresceu $59,12 \%$ no mesmo período (de 455 para 724); e que a taxa de congestionamento (relação entre casos pendentes e casos julgados) aumentou na primeira instância (de 7,05 para $7,95 \%$ ) e elevou-se na segunda instância (de 1,11 para 1,33\%), embora esta seja consideravelmente inferior àquela. Significa que, na primeira instância, de cada oito processos do acervo, um é julgado e, na segunda instância, cerca de $95 \%$ dos processos são julgados.

- nos indicadores de recorribilidade dos Juizados Especiais às Turmas Recursais, os recursos em processos cíveis $(14,67 \%$ em 2004) são cerca de treze vezes os recursos em processos criminais (1,11\% em 2004);

- nos indicadores de recorribilidade das Varas às Câmaras do TJERJ, observa-se tendência oposta à dos Juizados Especiais: os recursos em processos criminais $(45,20 \%$ em 2004) são cerca de duas vezes os recursos em processos cíveis $(24,48 \%$ em 2004);

- a taxa de recorribilidade interna no segundo grau (agravos e embargos) se manteve na média de $21,56 \%$, a indicar que em cada 100 decisões, 22 desafiam recursos;

- os indicadores de recorribilidade externa pertinentes ao Supremo Tribunal Federal decresceram entre 2001 e 2002 e apresentaram crescimento expressivo entre 2002 e 2004 (200\%), enquanto que os indicadores pertinentes ao Superior Tribunal de Justiça cresceram entre 2001 e 2002 e apresentaram tendência à estabilidade entre 2002 e $2004(44,44 \%)$;

- o indicador de tempo médio para a prolatação de sentenças, considerando-se os últimos três anos, apresenta redução de $223 \%$. expressa na média de 362 dias; o indicador de tempo médio para a prolatação de acórdãos apresenta tendência declinante, indicando a média de 142 dias entre a autuação e o julgamento, sinalizando ser este o tempo razoável típico dessa atividade; significa dizer que, somados os tempos médios de tramitação em $1^{\circ}$ e $2^{\circ}$ graus, uma demanda judicial começa e termina, no PJERJ, no tempo médio de 504 dias, ou seja, menos de 17 meses;

- o indicador relacionado ao total de sentenças ( $1^{\mathbf{a}}$ instância) apresenta variação crescente de $20 \%$ no período entre 2001 e 2002, e aumento de $2 \%$ entre 2003 e 2004 , totalizando 732.035 sentenças prolatadas em 2004;

- o indicador relacionado à quantidade de processos julgados na segunda instância apresenta crescimento contínuo anual de $10 \%$, totalizando 86.842 processos julgados em 2004;

- o indicador de grau de satisfação do usuário foi mensurado apenas a partir de pesquisa realizada na EMERJ, na $18^{\mathrm{a}}$ Câmara Cível e na $13^{\mathrm{a}}$ Vara Cível da Comarca da Capital, por serem os órgãos selecionados para participarem do processo de Certificação NBR ISO 9001:2000; os resultados observados foram positivos, destacando-se o grau de $94 \%$ de usuários satisfeitos com os serviços prestados pela $13^{\mathrm{a}}$ Vara Cível. 
Este capítulo apresenta o resumo dos indicadores de desempenho ${ }^{14}$, com o fim de permitir a apreciação conjunta da situação atual do Poder Judiciário do Estado do Rio de Janeiro. O resumo deverá ser complementado com as médias nacionais e/ou regionas, que estão sendo apuradas e aguardam divulgação dos respectivos índices pelo Supremo Tribunal Federal.

\section{Indicador de Desempenho}

Despesa do

Sistema Judicial sobre o PIB/RJ

Despesas com pessoal (orçamento) sobre a riqueza do Estado (PIB/RJ)

\section{Despesas de} bens e serviços sobre a riqueza do Estado (PIB/RJ)

Despesas do SJ sobre a despesa pública do

Estado

Despesas de pessoal no Sistema Judicial

Despesas do Sistema Judicial com bens e serviços

Despesas do Sistema Judicial por habitante

Magistrados por 100.000 habitantes (desembargadores)

\section{Fórmula \\ Finalidade}

$$
\begin{gathered}
D_{1}=(S J / \\
\text { PIB/RJ) }
\end{gathered}
$$

$D_{1.1}($ Pessoal $)=$

(PJ(Pessoal) / PIB/RJ)

Retratar a participação da dotação orçamentária do PJERJ no PIB estadual

Retratar a participação da despesa com pessoal do SJ na riqueza do Estado do Rio de Janeiro, expressa pelo seu PIB.

Retratar a participação das

$$
\begin{gathered}
D_{1.2}(\text { Cap })= \\
\text { (PJ (Cap) / } \\
\text { PIB/RJ) }
\end{gathered}
$$

despesas de custeio e de investimento do SJ na riqueza do Estado do Rio de Janeiro, expressa pelo seu PIB.

\section{Retratar a participação das}

$$
D_{2}=(S J / D T)
$$

despesas de custeio e de investimento do SJ na despesa do

$4,07 \%$ Estado do Rio de Janeiro.

\section{Retratar a participação das}

$D_{2,1}=(\operatorname{Prh} / \mathrm{SJ})$

despesas com pessoal do SJ no orçamento do SJ.

Retratar a participação das

$D_{2.2}=\left(B_{s} / S J\right)$ despesas com custeio e investimento do SJ no orçamento do SJ.

Retratar a contribuição de cada

$$
D_{3}=\left(S J / h_{1}\right)
$$
habitante do Estado do Rio de
Janeiro no orçamento do SJ.

Retratar a relação entre a quantidade de desembargadores (segunda inståncia) e a população $0,14 \%$ $\begin{array}{cc}\text { Resultado } & \text { Item do } \\ \text { em 2004 } & \text { RIGER }\end{array}$ Médla Nacional/ Regional

$$
0,42 \%
$$

\section{5}

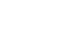

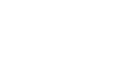

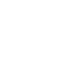


Indicador de

Desempenho

Magistrados por

100.000

habitantes

(juizes)

Servidores do Judiciário por 100.000

habitantes

Capacitaçāo de magistrados e

servidores

Recolhimento de

taxas e custas

sobre despesas

do Poder

Judiciário

Arrecadação da divida ativa do

Estado

\section{Depósitos}

judiciais em processos da Justiça Estadual

Percentual de despesas com informática

Número de computadores disponiveis por usuário

Número de computadores disponiveis por Servidor

Ocupação de área em $\mathrm{m}^{2}$

Custo do $\mathrm{m}^{2}$
Fórmula

Finalidade

Resultado

em 2004

Item do

RIGER

Retratar a relação entre a

$P_{1}=\left(M_{a g} / h_{2}\right)$

quantidade de juizes (primeira

instância) e a população do Estado

do Rio de Janeiro.

Retratar a relação entre a

$P_{2}=\left(P_{\text {aux }} / h_{2}\right)$

quantidade de servidores do SJ e a

população do Estado do Rio de

Janeiro.

Retratar o total de participaçōes de magistrados em capacitaçōes

5.641

Retratar o total de juizes

vitaliciandos

72

Retratar o total de participações de servidores em capacitaçōes

$40.212 \quad 6.3 .3$

Retratar a participação das receitas do SJ nas despesas do SJ.

$18,23 \%$

Retratar a participação das receitas provenientes de cobrança judicial $I_{2}=(i / P J)$

de dívidas com o Estado e com o

Município do Rio de Janeiro no

orçamento do PJERJ.

Retratar o volume financeiro atinente a depósitos judiciais.

RS4.314.500,32

Retratar a participação das

despesas com informática no

orçamento do SJ.

$3,55 \%$

Retratar a quantidade de

computadores disponiveis por

usuários, em termos de logins.

$\ln f_{2}=\left(C_{o m p} / U_{i}\right)$

Retratar a quantidade de

computadores disponiveis por

usuários, em terrmos de quantidade de servidores.

$m_{p}^{2}=\left(m^{2} / P_{\text {aux }}\right)$

Retratar a área física ocupada por servidor.

$26,69 \mathrm{~m}^{2}$

Retratar o custo especifico da quantidade de computadores disponiveis por usuários, em

R\$3.239,00
Média

Nacional/

Regional termos de logins. 
Indicador de Desempenho

Fórmula

Finalidade

Processos por $\mathrm{m}^{2}$

Casos novos por 100.000

habitantes

Casos novos por Juiz

Casos novos por Desembargador

Taxa de Crescimento de Casos

\section{Carga de} trabalho - 1" Instância e Juizados

Carga de trabalho - 2 Instảncia

$$
P_{m}^{2}=\left(P_{2003} / m^{2}\right)
$$
instalação. tombados - 2" Instáncia Juizados Especiais recursais Juizados/ T.Recursais

$$
\mathrm{C}_{2}=\left(\mathrm{Cl} / \mathrm{M}_{\mathrm{ag}}\right)
$$
tombados - $2^{\text {Instância }}$ da Justiça $-1^{a}$ instância

$\mathrm{Na} 2^{\mathrm{a}}$ instância

Nos Juizados Especiais

Nas Turmas Recursais

$$
\mathrm{K}=\underset{\mathrm{M}_{\mathrm{ag}}}{(\mathrm{CP}+\mathrm{Cl}) /}
$$

Especiais.
Retratar a ocupação especifica de processos por metro quadrado de

Retratar a demanda de novas açōes nas Varas, expressa como processos tombados - $1^{2}$ Instância

Retratar a demanda de recursos contra decisōes da $1^{\text {anstância, }}$ expressa como processos

$\mathrm{C}_{1}=\left(\mathrm{Cl} / \mathrm{h}_{2}\right) \quad$ Retratar a demanda por novas açōes nos Juizados, expressa como processos tombados -

Retratar a demanda de recursos contra decisōes dos Juizados

Especiais, expressa como processos tombados - Turmas

Retratar a demanda de novas açōes por juiz, expressa como processos tombados - $1^{\text {"Instância/ }}$

Retratar a demanda de novos recursos por desembargador, expressa como processos

Retratar a diversidade de realidades regionais, expressa como volume de processos tombados nas diferentes regiōes, considerando diferentes segmentos

457.586

49.572

Retratar a quantidade de trabalho (processos) virtualmente requerida a juizes em Varas e Juizados

Retratar a quantidade de trabalho (processos) virtualmente requerida a desembargadores nas Cámaras Civeis e Criminais.

$$
10,4 m^{2}
$$

10.1

$600,9 \quad 10.1$

$3.009,7 \quad 10.1$

$326,1 \quad 10.1$

$1.509,2 \quad 10.2$

571

10.2

10.3
Média

Nacional/

Regional 
Indicador de

Desempenho

Congestionamento

- $1^{\mathrm{a}}$ Instância e

Juizados

$$
\Gamma=(C P+C l) /
$$

Congestionamento - $2^{\mathrm{a}}$ Instância

Recorribitidade dos Juizados Especiais às

Turmas

Recursais

Recorribilidade das Varas ao Segundo Grau de Jurisdição

Recorribilidade interna

Recorribilidade ao STF

Recorribilidade ao STJ

Reforma da Decisão

Tempo Médio de Sentença / D Juizados

$\tau_{\text {Seg }}=\mathrm{R}_{\text {Seg }} / D$ $\tau_{\text {int }}=R_{\text {int }} / D_{\text {Seg }}$
Finalidade

$\begin{array}{cc}\text { Resultado } & \text { Item do } \\ \text { em } 2004 & \text { RIGER }\end{array}$

Média

Nacional/

Regional

Retratar a quantidade de processos represada nas Varas e nos Juizados Especiais, expressa pela relaçāo

$7,95 \%$

entre o volume do acervo e a quantidade de processos julgados.

Retratar a quantidade de processos represada nas Câmaras Civeis e Criminais, expressa pela relação entre o volume do acervo e a quantidade de processos julgados

Retratar o grau de definitividade de sentenças nos Juizados, expresso pela relação entre a quantidade de recursos às Turmas Recursais e a quantidade de sentenças em $\tau_{\text {Juizados }}=R_{\text {TRec }}$ processos civeis.

Retratar o grau de definitividade de sentenças nos Juizados, expresso pela relação entre a quantidade de recursos nas Turmas Recursais e a quantidade de sentenças em processos criminais.

Retratar o grau de definitividade de sentenças, expresso pela relaçāo entre a quantidade de recursos às sentenças nas Varas, em processos civeis.

$1,33 \% \quad 10.5$

$14,67 \%$

10.6

$1,11 \%$

10.6

$24,48 \%$

Retratar o grau de definitividade de sentenças, expresso pela relaçāo entre a quantidade de recursos às sentenças nas Varas, em

$45,20 \% \quad 10.7$ processos criminais.

Retratar o grau de definitividade de sentenças, expresso pela relação entre a quantidade de recursos internos e a quantidade de decisões.

$22,51 \% \quad 10.8$

$0,06 \quad 10.9$ ao STF.

$0.13 \quad 10.10$ ao STJ.

Retratar o grau de definitividade das sentenças prolatadas na $1^{\mathrm{a}}$ instância.

$73,76 \% \quad 10.11$

Retratar o tempo utilizado na prolatação de sentenças, expressa pela quantidade de dias entre distribuição do processo e prolatação da sentença, nos últimos 3 anos. 
Indicador de

Desempenho

Fórmula

Finalidade

Tempo Médio de

Acórdãos

Quantidade de

sentenças

Quantidade de

decisões em $2^{\circ}$

grau

Despesa com

assistência

judiciária gratuita $A_{1}=J G /(P \mid B / R J)$

sobre a riqueza do

Estado (PIB/RJ)

Assistência

Judiciária sobre

a despesa

pública total

Despesa com

assistência

judiciária gratuita

sobre a

população do

Estado

Custo unitário de processos

julgados

Número de

Pessoas

Atendidas

Grau de

Satisfação do

Usuário

Pertil da

Demanda
Retratar o tempo na prolataçāo de acórdāos, expressa pela quantidade de dias entre a autuaçāo do recurso e o seu julgamento.

Retratar o total de sentenças prolatadas (Varas + Juizados).

Retratar o total de acórdãos e decisōes prolatados em $2^{\circ}$ grau.

Retratar as despesas com a justiça gratuita, expressa pela relação entre despesa com assistência judiciária e riqueza do Estado do Rio de Janeiro (PIB).

Retratar as despesas com a justiça gratuita, expressa pela relaçāo entre despesa com assistência judiciária e as despesas do Estado do Rio de Janeiro (orçamento)

Retratar o custo por habitante da justiça gratuita, expressa pela $A_{3}=J G / h_{1}$ relaçāo entre despesa com assistência judiciária e 100.000 habitantes.

Retratar o custo final de processos julgados, expresso pela relaçāo entre a despesa do Sistema Judicial no

$\mathrm{C}_{0}=\left(\mathrm{SJ} / \mathrm{P}_{\text {Jug }}\right) \quad$ Estado do Rio de Janeiro e o total de jułgamentos $\left(1^{a}\right.$ Instảncia, $2^{a}$ Instância, Juizados e Turmas Recursais)

Retratar o grau de universalização da Justiça.

Retratar a percepçāo dos usuários sobre a qualidade dos serviços judiciários.

Retratar as características dos litigantes que procuram o PJERJ $\begin{array}{cc}\text { Resultado } & \text { Item do } \\ \text { em 2004 } & \text { RIGER }\end{array}$

Média

Nacional/

Regional

142 dias $\quad 10.12$

$732.035 \quad 10.13$

$107.447 \quad 10.13$

$0,03 \% \quad 11.1$

$0,23 \%$

11.2

$\mathrm{R} \$ 4,89$

R\$ 1.624 .60

11.4

Nạo disponivel

11.5

EMERJ $81 \%$ $16^{\circ}$ Camara - $76 \%$ $13^{\circ}$ vara Civel

$$
94 \%
$$

Nảo disponivel

12 


\section{ANEXO}

- Anexo - Quadro de Despesas

\section{Anexo - Quadro de Despesas (I)}

\begin{tabular}{|c|c|c|c|c|c|c|}
\hline \multirow{3}{*}{$\begin{array}{l}\text { Porcentagem da despesa do Sistema Judicial - SJ } \\
\text { sobre o PIB/RJ }\end{array}$} & \multicolumn{6}{|c|}{2001} \\
\hline & \multicolumn{3}{|c|}{ Com precatorios } & \multicolumn{3}{|c|}{ Sem precatórios } \\
\hline & SJ & PIB/RJ & D1 & Lu & PIB/RJ & D1 \\
\hline Dotação Orçamentária & 894.415 .590 & \multirow{4}{*}{168.083 .930 .000} & $0,537 x$ & 842.609 .430 & \multirow{4}{*}{168.083 .930 .000} & $0,50 x$ \\
\hline Despesa Empennada & 866.182 .390 & & $0,52 x$ & 814.376 .230 & & $0,40 x$ \\
\hline Despesa Liquidada & 846.512 .710 & & $0,50 x$ & 794706.550 & & $0.47 \%$ \\
\hline Despesa Paga & 807.796 .460 & & $0,48 x$ & 704.184 .140 & & $0,42 x$ \\
\hline
\end{tabular}

\begin{tabular}{|c|c|c|c|c|c|c|}
\hline \multirow{3}{*}{$\begin{array}{l}\text { Porcentagem da despesa do Sistema Judicial - SJ } \\
\text { sobre o PIB/RJ }\end{array}$} & \multicolumn{6}{|c|}{2002} \\
\hline & \multicolumn{3}{|c|}{ Com procatórios } & \multicolumn{3}{|c|}{ Som precatórlos } \\
\hline & SJ & PIB/RJ & D1 & SI & PIB/AN & D1 \\
\hline Dotaçāo Orçamentária & 1.061 .215 .960 & \multirow{4}{*}{191.967 .599 .000} & $0,56 \%$ & 946.184 .090 & \multirow{4}{*}{191.987 .599 .000} & $0,48 \%$ \\
\hline Despesa Empennada & 1.059 .384 .990 & & $0,55 \%$ & 924.353120 & & $0,48 \%$ \\
\hline Despesa Liquidada & 1.028 .581 .710 & & $0.54 \%$ & 894549840 & & $0,47 \%$ \\
\hline Despesa Paga & 843.550 .210 & & $0,44 x$ & 843.550 .210 & & $0,44 x$ \\
\hline
\end{tabular}

\begin{tabular}{|c|c|c|c|c|c|c|}
\hline \multirow{3}{*}{$\begin{array}{c}\text { Porcentagem da despesa do Sistema Judicial - SJ } \\
\text { sobro o PIB/RJ }\end{array}$} & \multicolumn{6}{|c|}{2003} \\
\hline & \multicolumn{3}{|c|}{ Com precalórios } & \multicolumn{3}{|c|}{ Som precalórios } \\
\hline & Su & PIB/RJ & D1 & SJ & PIB/RJ & D1 \\
\hline Dotaçào Orçamentária & 1.384 .423 .350 & \multirow{4}{*}{213.500 .784 .000} & $0,85 x$ & 1.272 .021 .690 & \multirow{4}{*}{213.500 .764 .000} & $0,00 \%$ \\
\hline Despesa Empenhada & 1.324 .055 .550 & & $0.62 \%$ & 1.212 .453 .890 & & $0.57 \times$ \\
\hline Despesa Liquidada & 1.282 .152 .880 & & $0.80 x$ & 1169.751220 & & $0.55 \times$ \\
\hline Despesa Paga & 1.079 .970230 & & $0.51 \%$ & 1079970230 & & 0,518 \\
\hline
\end{tabular}

\begin{tabular}{|c|c|c|c|c|c|c|}
\hline \multirow{3}{*}{$\begin{array}{l}\text { Porcentagem da despesa do Sistema Judicial - SJ } \\
\text { sobre o PIB/RJ }\end{array}$} & \multicolumn{6}{|c|}{2004} \\
\hline & \multicolumn{3}{|c|}{ Com procentórlos } & \multicolumn{3}{|c|}{ Sem precatorios } \\
\hline & SN & PIB/RJ & D1 & Su & PIB/RJ & Di \\
\hline Dotação Orçamentária & 1.438 .815 .173 & \multirow{4}{*}{236.609 .000 .000} & $0.07 x$ & 1.330 .348161 & \multirow{4}{*}{236607.624 .000} & $0.56 x$ \\
\hline Despesa Empenhada & 1.393 .068 .697 & & $0,05 \%$ & 1.284 .791 .361 & & $0,54 x$ \\
\hline Despesa Liquidada & 1361.675 .833 & & $0,64 x$ & 1.253 .309 .497 & & $0.53 \times$ \\
\hline Despesa Paga & 1.192 .287 .124 & & $0,50 \%$ & +192.232 .208 & & 0,500 \\
\hline
\end{tabular}




\section{Anexo - Quadro de Despesas (II)}

\begin{tabular}{|c|c|c|c|c|c|c|}
\hline \multirow{3}{*}{$\begin{array}{l}\text { Porcentagem da despesa com pessosl sobre o } \\
\text { PlB/RJ }\end{array}$} & \multicolumn{6}{|c|}{2001} \\
\hline & \multicolumn{3}{|c|}{ Com procatórios } & \multicolumn{3}{|c|}{ Sem precatórios } \\
\hline & 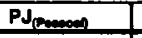 & PIB/RJ & D1 1 teneses & $\mathbf{P J}_{\text {tancoun }}$ & PIBAN & D1 1 manent \\
\hline Dotaçāo Orçamentária & 717.031 .110 & \multirow{4}{*}{168.063 .930 .000} & $0.43 \times$ & 687259430 & \multirow{4}{*}{168.083 .930 .000} & $0.41 \%$ \\
\hline Despesa Empenhada & 716.256 .730 & & $0,43 \%$ & 686.485 .050 & & $0,41 \%$ \\
\hline Despesa Liquidada & 716.205 .510 & & $0,43 \%$ & 686.433 .830 & & $0.41 \%$ \\
\hline Despesa Paga & 707.306 .580 & & $0.42 \%$ & 625.738027 & & $0.37 x$ \\
\hline
\end{tabular}

\begin{tabular}{|c|c|c|c|c|c|c|}
\hline \multirow{3}{*}{$\begin{array}{l}\text { Porcentagem da despesa com pessosl sobre o } \\
\text { PIB/RJ }\end{array}$} & \multicolumn{6}{|c|}{2002} \\
\hline & \multicolumn{3}{|c|}{ Com precatórios } & \multicolumn{3}{|c|}{ Sem precetórios } \\
\hline & $P J_{\text {(noweoned }}$ & PIB/RN & D1 & $P \mathbf{P}_{\text {(1) }}$ & PIB/W & D1 \\
\hline Dotaçāo Orçamentária & 748.990 .450 & \multirow{4}{*}{191967.599 .000} & $0,39 \%$ & 730.634 .880 & \multirow{4}{*}{191.987 .599 .000} & $0,30 \%$ \\
\hline Despesa Empennada & 748.168 .860 & & $0,39 x$ & 729.813 .290 & & $0.30 \%$ \\
\hline Despesa Liquidada & 748.009 .310 & & $0,39 x$ & 729.733 .740 & & $0.30 x$ \\
\hline Despesa Paga & 687.901 .920 & & $0,36 x$ & 607.901 .920 & & $0,36 \%$ \\
\hline
\end{tabular}

\begin{tabular}{|c|c|c|c|c|c|c|}
\hline \multirow{3}{*}{$\begin{array}{l}\text { Porcentagem da despess com pessosl sobre o } \\
\text { PIB/RJ }\end{array}$} & \multicolumn{6}{|c|}{2003} \\
\hline & \multicolumn{3}{|c|}{ Com procatórios } & \multicolumn{3}{|c|}{ Sem precatórios } \\
\hline & $P J_{\text {preaces }}$ & PIB/A & D1 & $\mathbf{P} \mathbf{J}_{\text {(never }}$ & PIB/RJ & D1 \\
\hline Dotaçăo Orçamentária & 956.291 .660 & \multirow{4}{*}{213.500 .784 .000} & $0,45 \%$ & 922.025 .970 & \multirow{4}{*}{213.500 .784 .000} & $0,43 \%$ \\
\hline Despesa Empenhada & 952.627 .490 & & $0,45 \%$ & 918.361 .600 & & $0,43 x$ \\
\hline Despesa Liquidada & 952.627 .490 & & $0,45 \%$ & 918.361 .600 & & 0.4076 \\
\hline Despesa Paga & 827.824 .780 & & $0,39 \%$ & 827.824 .780 & & 0,390 \\
\hline
\end{tabular}

\begin{tabular}{|c|c|c|c|c|c|c|}
\hline \multirow{3}{*}{$\begin{array}{l}\text { Porcentagem da despess com pessosl sobre o } \\
\text { PIB/RJ }\end{array}$} & \multicolumn{6}{|c|}{2004} \\
\hline & \multicolumn{3}{|c|}{ Com precatórlos } & \multicolumn{3}{|c|}{ Sem precetórlos: } \\
\hline & $P \mathbf{J}_{\text {ances }}$ & PIB/AJ & D1/pongen & 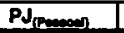 & PIRN & 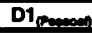 \\
\hline Dotaçāo Orçamentária & 1.090 .112 .700 & \multirow{4}{*}{236.600 .000 .000} & $0,51 \%$ & 998.143 .161 & \multirow{4}{*}{236.607624 .000} & 0.426 \\
\hline Despesa Empenhada & 1088.309 .650 & & 0,518 & 996.340 .114 & & $0,02 x$ \\
\hline Despesa Liquidada & 1.080 .309650 & & $0,51 x$ & 996.340 .114 & & $0.02 x$ \\
\hline Despesa Paga & 943.436806 & & $0,44 x$ & 943409579 & & $0.40 x$ \\
\hline
\end{tabular}




\section{Anexo - Quadro de Despesas (III)}

\begin{tabular}{|c|c|c|c|c|c|c|}
\hline \multirow{3}{*}{$\begin{array}{l}\text { Porcentagem da despesa do Sistema Judicial - SJ } \\
\text { sobre a Despesa Total do Estado }\end{array}$} & \multicolumn{6}{|c|}{2001} \\
\hline & \multicolumn{3}{|c|}{ Com precatórios } & \multicolumn{3}{|c|}{ Sem precatórios } \\
\hline & Sa & DT & $\mathrm{D} 2$ & SJ & DT & $\mathbf{D 2}$ \\
\hline Dotaçāo Orçamentária & 894.415 .590 & 19.531 .264 .000 & 4,58* & 842.609430 & 19531264.000 & $4.31 \%$ \\
\hline Despesa Empenhada & 866.182390 & 17.958649 .480 & $4,82 \%$ & 814376230 & 17958.649 .480 & 4.534 \\
\hline Despesa Liquidada & 846.512710 & 17.767461 .740 & $4,76 \%$ & 794706550 & 17767.461740 & 4,478 \\
\hline Despesa Paga & 807.796460 & 17151.182 .260 & $4,71 \%$ & 704184.140 & 17.151182 .260 & $4,11 \%$ \\
\hline
\end{tabular}

\begin{tabular}{|c|c|c|c|c|c|c|}
\hline \multirow{3}{*}{$\begin{array}{l}\text { Porcentagem da despesa do Sistema Judicial - SJ } \\
\text { sobre a Despesa Total do Estado }\end{array}$} & \multicolumn{6}{|c|}{2002} \\
\hline & \multicolumn{3}{|c|}{ Com precatórios } & \multicolumn{3}{|c|}{ Sem precatórios } \\
\hline & SJ & DT & D2 & S.J & DT & D2 \\
\hline Dotaçāo Orçamentaria & 1.081 .215960 & 22638299490 & $4.78 \%$ & $946,94.090$ & 22638299.490 & $4.18 \%$ \\
\hline Despesa Empenhada & 1.059384990 & 20396932.180 & $5.19 \%$ & 924353120 & 20396932180 & $4.53 \%$ \\
\hline Despesa Liquidada & 1029.581710 & 20224072.650 & $5.09 \%$ & 894549.840 & 20224.072 .650 & $9.42 \%$ \\
\hline Despesa Paga & 843.550 .210 & 18855.738 .360 & $4.47 \%$ & 843550.210 & 18.855 .738 .360 & $4,47 \times$ \\
\hline
\end{tabular}

\begin{tabular}{|c|c|c|c|c|c|c|}
\hline \multirow{3}{*}{$\begin{array}{l}\text { Porcentagem da despesa do Sistema Judicial - SJ } \\
\text { sobre a Despesa Total do Estado }\end{array}$} & \multicolumn{6}{|c|}{2003} \\
\hline & \multicolumn{3}{|c|}{ Com precatórios } & \multicolumn{3}{|c|}{ Sem precatórios } \\
\hline & SJ & DT & D2 & Su & DT & D2 \\
\hline Dotaçāo Orçamentária & 1.384 .423 .350 & 28623874.820 & 4,846 & 1.272 .021 .690 & 28.623 .874 .620 & 4,44 \\
\hline Despesa Empenhada & 1.324 .255550 & 24.404 .965 .510 & $5,43 \%$ & 1.212 .453890 & 24.404 .965 .510 & $4,97 \%$ \\
\hline Despesa Liquidada & 1.282 .152880 & 23.990 .696 .050 & 5,346 & 1.169 .751 .220 & 23990.696 .050 & $4,88 x$ \\
\hline Despesa Paga & 1.079 .970 .230 & 22.125 .155 .070 & $4,80 \%$ & 1079.970230 & 22.125 .155 .070 & 4,806 \\
\hline
\end{tabular}

\begin{tabular}{|c|c|c|c|c|c|c|}
\hline \multirow{3}{*}{$\begin{array}{c}\text { Porcentagem da despesa do Sistema Judicial - SJ } \\
\text { sobre a Despesa Total do Estado }\end{array}$} & \multicolumn{6}{|c|}{2004} \\
\hline & \multicolumn{3}{|c|}{ Com precatórios } & \multicolumn{3}{|c|}{ Sem precatórios } \\
\hline & SJ & DT & D2 & S. & DT & D2 \\
\hline Dotaçāo Orçamentária & 1438.815173 & & - & 1.330 .348 .161 & & 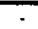 \\
\hline Despesa Empenhada & 1.393 .068 .697 & & - & $1284.79: 36:$ & & - \\
\hline Despesa Liquidada & 1.361675 .833 & & . & 1253398497 & & - \\
\hline Despesa Paga & 1192.287124 & & - & 1192232208 & & - \\
\hline
\end{tabular}




\section{Anexo - Quadro de Despesas (IV)}

\begin{tabular}{|c|c|c|c|c|c|c|}
\hline \multirow{3}{*}{$\begin{array}{l}\text { Porcentagem da despesa com pessoal sobre as } \\
\text { Despesas do Sistems Judicial }\end{array}$} & \multicolumn{6}{|c|}{2001} \\
\hline & \multicolumn{3}{|c|}{ Com precalórios } & \multicolumn{3}{|c|}{ Sem procatórios } \\
\hline & S.J & Prh & D3 & Su & Prh & D3 \\
\hline Dotaçāo Orçamentária & 894.415 .590 & 717.031 .110 & $80,17 x$ & 842.609 .430 & 687.259 .430 & $01,56 \%$ \\
\hline Despesa Empenhada & 866.182 .390 & 716.256 .730 & $82,69 \%$ & 814.376 .230 & 686.485 .050 & $84,30 \%$ \\
\hline Despesa Liquidada & $846512>10$ & 16205510 & 84,617 & 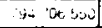 & $2000+3030$ & 86.389 \\
\hline Despesa Paga & 807.796 .460 & 707.306 .580 & $87,56 x$ & 704.184 .140 & 625.738 .027 & $88,86 x$ \\
\hline
\end{tabular}

\begin{tabular}{|c|c|c|c|c|c|c|}
\hline \multirow{3}{*}{$\begin{array}{l}\text { Porcentagem da despesa com pessoal sobre as } \\
\text { Despesas do Sisteme Judictal }\end{array}$} & \multicolumn{6}{|c|}{2002} \\
\hline & \multicolumn{3}{|c|}{ Com precatórios } & \multicolumn{3}{|c|}{ Sem procatórios } \\
\hline & SJ & Prh & D3 & SJ & Prh & D3 \\
\hline Dotação Orçamentária & t.081.215.960 & 748.990 .450 & $69.27 \times$ & 946.184 .090 & 730634.880 & $77.22 \%$ \\
\hline Despesa Empenhada & 1.059384 .990 & 748.168 .860 & $70,62 \%$ & 924353.120 & 729.813 .290 & $78,95 \%$ \\
\hline Despesa Liquidada & 1.029 .581 .710 & 748.089 .310 & $72.66 \%$ & 894.549 .840 & 729.733 .740 & $81.50 x$ \\
\hline Despesa Paga & 843.550 .210 & 687.901 .920 & $01,55 x$ & 843.550 .210 & 687.901 .920 & $01,55 x$ \\
\hline
\end{tabular}

\begin{tabular}{|c|c|c|c|c|c|c|}
\hline \multirow{3}{*}{$\begin{array}{l}\text { Porcentagem da despesa com pessosal sobre as } \\
\text { Despesas do Sistema Judiclal }\end{array}$} & \multicolumn{6}{|c|}{2003} \\
\hline & \multicolumn{3}{|c|}{ Com precatórios } & \multicolumn{3}{|c|}{ Sem precatórios } \\
\hline & SJ & Prh & D3 & Sa & Prh & D3 \\
\hline Dotaçāo Orçamentária & 1.384 .423 .350 & 956.291 .860 & $69,08 \%$ & 1.272 .021 .690 & 922.025 .970 & $72,49 \%$ \\
\hline Despesa Empenhada & 1.324 .855 .550 & 962.627 .490 & $71,90 \%$ & 1.212 .453 .890 & 918.361 .600 & $75,74 \%$ \\
\hline Despesa Liquidada & 1.282 .152 .880 & 952.627 .490 & $74,30 \%$ & $\$ .169 .751 .220$ & 918.361 .600 & $78,51 \%$ \\
\hline Despesa Paga & 1.079 .970 .230 & 827.824 .780 & $76,65 x$ & 1.079 .970 .230 & 827.824 .780 & $76,65 \%$ \\
\hline
\end{tabular}

\begin{tabular}{|c|c|c|c|c|c|c|}
\hline \multirow{3}{*}{$\begin{array}{l}\text { Poreentegem da despese com pessoal sobre as } \\
\text { Despesas do Sistema Judicial }\end{array}$} & \multicolumn{6}{|c|}{2004} \\
\hline & \multicolumn{3}{|c|}{ Com precatórios } & \multicolumn{3}{|c|}{ Sem precatórios } \\
\hline & SJ & Prh & D3 & SI & Pm & D3 \\
\hline Dotaçāo Orçamentária & 1.438 .815 .173 & 1.090 .112 .700 & $75,76 \%$ & 1.330 .348 .161 & 998.143 .161 & $75,00 \%$ \\
\hline Despesa Empenhada & 1.393 .068 .697 & 1.088 .309 .650 & 78,124 & 1.284791 .361 & 996.340 .114 & $77,55 \%$ \\
\hline Despesa Liquidada & 1.361 .675 .833 & 1.009 .309 .650 & $79,92 \%$ & 1.253 .398 .497 & 996.340 .114 & $79,49 \%$ \\
\hline Despesa Paga & 1.192 .287 .124 & 943.436 .806 & 79,134 & 1.192 .232 .200 & 943.409 .579 & $79.13 x$ \\
\hline
\end{tabular}




\section{Anexo - Quadro de Despesas (V)}

\begin{tabular}{|c|c|c|c|c|c|c|}
\hline \multirow{3}{*}{$\begin{array}{l}\text { Porcentagem da despece com bens e serviços } \\
\text { sobre as Despesas do Sistema Judiclal }\end{array}$} & \multicolumn{6}{|c|}{2001} \\
\hline & \multicolumn{3}{|c|}{ Com precatórios } & \multicolumn{3}{|c|}{ Sem procatórios } \\
\hline & SJ & Bs & D4 & S.J & Bs & DA \\
\hline Dotaçāo Orçamentária & 894.415 .590 & 177.384 .470 & $19.23 \%$ & 842.609 .430 & 155350.000 & 12,444 \\
\hline Despesa Empenhada & 866.182 .390 & 149.925 .650 & $17,31 \%$ & 814.376 .230 & 127.691 .180 & $15,70 x$ \\
\hline Despesa Liquidada & 846.512 .710 & 130.307 .190 & $15,39 x$ & 794706.550 & 108.272720 & $13,62 x$ \\
\hline Despesa Paga & 807.796 .460 & 100.479 .840 & $12,44 \%$ & 704.184 .140 & 78.445 .370 & $11,14 x$ \\
\hline
\end{tabular}

\begin{tabular}{|c|c|c|c|c|c|c|}
\hline \multirow{3}{*}{$\begin{array}{l}\text { Porcentagem da despesa com bens e serviços } \\
\text { sobre as Despesas do Sistema Judiclal }\end{array}$} & \multicolumn{6}{|c|}{2002} \\
\hline & \multicolumn{3}{|c|}{ Com precatórios } & \multicolumn{3}{|c|}{ Sem precatórios } \\
\hline & SJ & Bs & D4 & S.J & $B:$ & DA \\
\hline Dotação Orçamentánia & 1.081 .215 .960 & 332.225 .490 & $30,73 \%$ & 946.184 .090 & 215.549 .190 & $22,70 x$ \\
\hline Despesa Empenhada & 1.059 .364 .990 & 311.216 .130 & $29,39 \%$ & 924.353 .120 & 194.539 .830 & $21,05 x$ \\
\hline Despesa Liquidada & 1.029 .581 .710 & 281.492 .390 & $27.34 \%$ & 894.549840 & 164.816 .090 & $11,42 \pi$ \\
\hline Despesa Paga & 843.550 .210 & 155.648 .270 & $10.45 x$ & 843.550 .210 & 155.640 .270 & $18,45 x$ \\
\hline
\end{tabular}

\begin{tabular}{|c|c|c|c|c|c|c|}
\hline \multirow{3}{*}{$\begin{array}{l}\text { Porcentagem da despesa com bens e serviços } \\
\text { sobre as Despesas do Sistema Judicial }\end{array}$} & \multicolumn{6}{|c|}{2003} \\
\hline & \multicolumn{3}{|c|}{ Com precatórios } & \multicolumn{3}{|c|}{ Sem precstórios } \\
\hline & SN & Bs & D4 & SJ & Bs & D4 \\
\hline Dotação Orçamentária & 1.384 .423 .350 & 428.131 .480 & $30,92 \%$ & 1272.021690 & 349.995720 & $27,51 \%$ \\
\hline Despesa Empenhada & 1.324 .855 .550 & 372.318 .050 & $28,10 x$ & 1212.453 .890 & 294.182 .290 & $24,26 \%$ \\
\hline Despesa Liquidada & 1.282 .152 .880 & 329.525 .380 & $25,70 \%$ & 1.169 .751 .220 & 251.389 .620 & $21,40 \%$ \\
\hline Despesa Paga & 1.079 .970 .230 & 252.145 .450 & $23,35 x$ & 1.079 .970 .230 & 252.145 .450 & $23,25 \%$ \\
\hline
\end{tabular}

\begin{tabular}{|c|c|c|c|c|c|c|}
\hline \multirow{3}{*}{$\begin{array}{l}\text { Porcentagem da despesa com bens e serviços } \\
\text { sobre as Despesas do Slstema Judiclal }\end{array}$} & \multicolumn{6}{|c|}{2004} \\
\hline & \multicolumn{3}{|c|}{ Com precatórios } & \multicolumn{3}{|c|}{ Sem procatórlos } \\
\hline & SJ & Bs & D4 & SJ & Bs & DA \\
\hline Dotação Orçamentária & 1.438.915.173 & 348.702 .473 & $24,24 x$ & 1.330 .348 .161 & 332.205 .000 & $24.97 x$ \\
\hline Despesa Empenhada & 1.393.068.697 & 304.759 .047 & 21,2046 & 1.284 .791 .361 & 288.451 .247 & $22,45 x$ \\
\hline Despesa Liquidada & 1.361 .675 .833 & 273.366 .183 & 20,000 & 1.253 .390 .497 & 257.058 .360 & $20,51 x$ \\
\hline Despesa Paga & 1.192.287.124 & 248.1650.318 & $20,87 \times$ & 1.192 .232 .208 & 248.822 .630 & $20,87 x$ \\
\hline
\end{tabular}




\section{Anexo - Quadro de Despesas (VI)}

\begin{tabular}{|c|c|c|c|c|c|c|}
\hline \multirow{3}{*}{ Valor da despesa por habitante } & \multicolumn{6}{|c|}{2001} \\
\hline & \multicolumn{3}{|c|}{ Com procatórios } & \multicolumn{3}{|c|}{ Sem precatórios } \\
\hline & SI & Populaçăo & D5 & SJ & Populaç3o & D5 \\
\hline Dotação Orçarnentária & 894.415 .590 & \multirow{4}{*}{14558.545} & AS 61.44 & 842.609 .430 & \multirow{4}{*}{14558.545} & As 57.08 \\
\hline Despesa Empenhada & 866.182 .390 & & AS 59,50 & 814.376 .230 & & AS 55,94 \\
\hline Despesa Liquidada & 846.512 .710 & & RS 58,15 & 794.706550 & & $R 550,50$ \\
\hline Despesa Paga & 807796.460 & & RS 55,49 & 704184140 & & RS 46,37 \\
\hline
\end{tabular}

\begin{tabular}{|c|c|c|c|c|c|c|}
\hline \multirow{3}{*}{ Valor da despesa por habitante } & \multicolumn{6}{|c|}{2002} \\
\hline & \multicolumn{3}{|c|}{ Com precatórios } & \multicolumn{3}{|c|}{ Sem procatónios } \\
\hline & SI & Populaçăo & D5 & S. & Populacilo & DS \\
\hline Dotaçāo Orçamentána & 1.081 .215 .960 & \multirow{4}{*}{14724475} & As 73,43 & 946184.090 & \multirow{4}{*}{14724.475} & AS 84,26 \\
\hline Despesa Empenhada & 1.059 .384 .990 & & A\$ 71,95 & 924.353 .120 & & AS $62,7 \mathrm{~B}$ \\
\hline Despesa Liquidada & 1029.581710 & & A\$ 69.92 & 894549.840 & & AS 80,75 \\
\hline Despesa Paga & 843.550 .210 & & As 57,29 & 843.550 .210 & & AS 57,20 \\
\hline
\end{tabular}

\begin{tabular}{|c|c|c|c|c|c|c|}
\hline \multirow{3}{*}{ Valor da despesa por habitante } & \multicolumn{6}{|c|}{2003} \\
\hline & \multicolumn{3}{|c|}{ Com procatórios } & \multicolumn{3}{|c|}{ Sem precalórios } \\
\hline & S. J & Populaçào & D5 & SI & Populaçáo & DS \\
\hline Dotação Orçamentária & 1.384 .423 .350 & \multirow{4}{*}{14.879 .118} & As 93,04 & 1.272 .021 .690 & \multirow{4}{*}{14.879 .118} & Rs 85,49 \\
\hline Despesa Empenhada & 1.324 .855 .550 & & Rs 20,04 & 1.212 .453 .890 & & AS 31,49 \\
\hline Despesa Liquidada & 1.282152 .880 & & Rs 86,17 & 1.169 .751 .220 & & As 78,62 \\
\hline Despesa Paga & 1.079 .970 .230 & & As 72,58 & 1.079 .970 .230 & & A5 72,50 \\
\hline
\end{tabular}

\begin{tabular}{|c|c|c|c|c|c|c|}
\hline \multirow{3}{*}{ Valor da despese por habltante } & \multicolumn{6}{|c|}{2004} \\
\hline & \multicolumn{3}{|c|}{ Com precatórios } & \multicolumn{3}{|c|}{ Sem precentórios } \\
\hline & SJ & População & D5 & SJ & Populaçao & D5 \\
\hline Dotaçăo Orçamentária & 1.438 .815 .173 & \multirow{4}{*}{15.203 .750} & RS 94,64 & 1330.348 .161 & \multirow{4}{*}{15203.750} & R5 87,50 \\
\hline Despesa Empenhada & 1.393 .068697 & & AS 91,63 & 2884791361 & & RE 80,50 \\
\hline Despesa Liquidada & 1.361 .675 .833 & & As 20,58 & 1.253 .398 .497 & & As 82,44 \\
\hline Despesa Paga & 1.192 .287 .124 & & AS 79,42 & 1.192 .232 .200 & & As 78,42 \\
\hline
\end{tabular}




\section{Cooperação Judiciária Internacional}

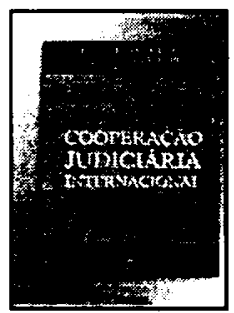

\section{Paulo Borba Casella e Rodrigo} Elian Sanchez (Orgs.)

Ref. 0388

Encadernado

669 págs.

Form. $16 \times 23$

2002

ISBN 85-7147-701-9

Traz a compilação da totalidade de Tratados de Cooperação Judiciária, em amplo sentido, firmados pelo Brasil e em vigência, sem excluir alguns mais recentes, todavia não aprovados e promulgados, porém inseridos aqui, visando manter sua atualidade.

\section{Cooperação Jurídica Penal no Mercosul Novas Possibilidades}

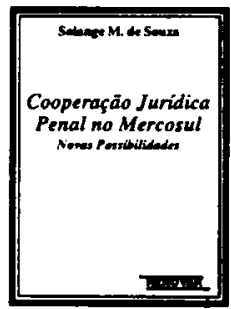

\section{Solange $M$. de Souza}

Ref. 0321

Broctura

538 págs.

Form. 13,5×21

2001

ISBN 85-7147-263-7

Este livro divide-se em duas partes. $\mathrm{Na}{ }^{1}{ }^{\mathrm{a}}$, conceitua-se a estrutura jurídica do Mercosul e o funcionamento de sua recepção pelos ordenamentos jurídicos dos países que 0 compõem, além dos princípios que informam o processo penal internacional nesses países. Na $2^{\mathrm{a}}$, analisa-se a cooperação penal internacional, passando por seu histórico no Brasil, sua conceituação, para afinal proceder-se ao estudo do tema no contexto do Mercosul.

\section{Mercosul e Personalidade Jurídica Internacional As relaçōes externas do bloco sub-regional pós-Ouro Preto}

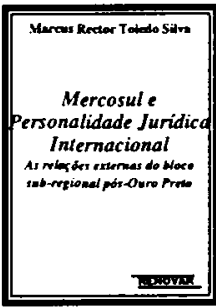

\section{Marcus Rector Toledo Silva}

Ref. 0240

Brochura

314 págs.

Form. $13,5 \times 21$

1999

ISBN 85-7147-145-2

São vistas as relações externas do Mercosul, compreendendo o período que vai desde a implantação da União Aduaneira, em janeiro de 1995, até o término da presidência pro tempore do Brasil no Mercosuf, em dezembro de 1998. A escolha deste período deve-se ao fato de ele representar o momento a partir do qual a Organização passou a ser apontada como detentora de personalidade jurídica de Direito Internacional, o que foi expressamente reconhecido pelo Protocolo de Ouro Preto.

\section{Mercosul: Integração Regional e Globalização}

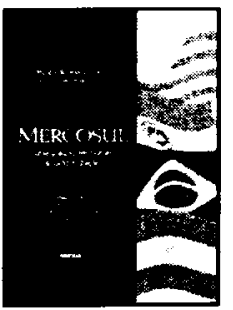

Paulo Borba Casella (coord.)

Ref. 0267

Encadernado

1.150 págs.

Form. $16 \times 23$

2000

ISBN $85-7147 \cdot 170-3$

Obra coletiva de leitura necessária para quem busca, na prática, conhecer, o regime de concorrência, o embasamento legal em matéria contratual, a aplicabilidade dos direitos humanos, do direito ambiental, a solução de controvérsias compreendendo a arbitragem e 0 Tribunal, 0 Direito da Concorrência, até de problemas relacionados com a livre circulação de jogadores de futebol no Mercosul, entre outros temas abordados. 